\title{
NITRIFICATION IN DUTCH HEATHLAND SOILS
}

\author{
ONTVANGEN \\ 15 NOV. 1989 \\ CB-KARDEX
}

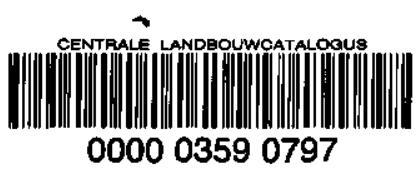


Promotoren: dr. A.J.B. Zehnder, hoogleraar in de microbiologie

dr. W. Harder, hoogleraar in de microbiologie aan de Rijksuniversiteit Groningen,

Co-promotor: dr. H.J. Laanbroek, hoofd afdeling bodembiologie, Instituut voor Oecologisch Onderzoek 


$$
\text { NNO8201, 1315 }
$$

W. DE BOER

\section{NITRIFICATION IN DUTCH HEATHLAND SOILS}

\section{Proelschrift}

ter verkrijging van de graad van

doctor in de landbouwwetenschappen,

op gezag van de rector magnificus,

dr. H.C. van der Plas,

in het openbaar te verdedigen

op vrijdag 10 november 1989

des namiddags te vier uur in de aula

van de Landbouwuniversiteit te Wageningen 
omslagontwerp: Klaas Jan Woudstra

grafische verzorging: Nicole Tolmeyer

This study was carried out at the Institute for Ecological Research, lleteren, The Netherlands. 


\section{STELLINGEN}

Bekalking van de Nederlandse bossen ter verhoging van de boom-vitaliteit is een hachelijke maatregel omdat op dit moment niet kan worden overzien in hoeverre dit zal leiden tot verontreiniging van het grondwater met nitraat.

Toxiciteit van salpeterig zuur kan slechts in bepaalde gevallen een verklaring geven voor het het feit dat veel chemolithotrofe nitrificerende bacteriën bij lage pH niet aktief zijn. (Anthonisen et al. (1976) J. Water Pollut. Contr. Fed. 48, 835-850).

Het optreden van verliezen aan gasvormige stikstof ten gevolge van ontleding van salpeterig zuur tijdens nitrificatie bij lage $\mathrm{pH}$ is niet aangetoond.

(Van Cleemput and Baert (1984) Plant and Soil 76, 233-241).

Het verdient aanbeveling de toepassingsmogelijkheden van zuur-tolerante, chemolithotrofe nitrificeerders in installaties voor ammoniak-verwijdering te onderzoeken.

De interpretatie dat stimulatie van de nitraatproduktie in zure bodems door organische stikstof-verbindingen duidt op heterotrofe nitrificatie is aanvechtbaar.

(Kuenen and Robertson (1987) in: The nitrogen and sulphur cycles, Cambridge University Press. pp. 162-218).

Bij de bestudering van trofische interakties in de bodem wordt er ten onrechte vaak van uitgegaan dat de bodem een statisch systeem is.

Alvorens 'probes' met succes kunnen worden gebruikt voor populatie-onderzoek aan microorganismen, moet worden aangetoond dat de hoeveelheid per cel van het 'op te sporen' genetische materiaal onafhankelijk is van de groeifase waarin de micro-organismen zich bevinden.

Bij de verkoop van land- en tuinbouwprodukten dient te worden aangegeven met welke bestrijdingsmiddelen zij zijn behandeld.

De aankomende vergrijzing van de Nederlandse bevolking moet niet als een afzonderlijk probleem worden beschouwd maar als de laatste fase van een overbevolkingsprobleem.

Fundamenteel onderzoek is vaak een elitaire aangelegenheid.

$\mathrm{Zij}$ die zich bezighouden met het leed van transgene dieren zouden zich ook moeten bekommeren om wat er via selectie zoal van Canis familiaris en Felis catus is geworden.

Stilstaan bij werk aan de weg komt de verkeersveiligheid niet ten goede.

Ouderdom en ouderschap vormen de ingrediënten voor vruchtbare discussies. 
aan mijn moeder aan Marga 
Graag maak ik van deze gelegenheid gebruik om al diegenen die mij op enigerlei wijze hebben geholpen bij het promotie-onderzoek en bij de totstandkoming van het proefschrift van harte te bedanken.

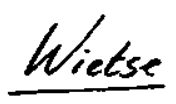




\section{CONTENTS}

\section{PAGE}

I INTRODUCTION

II NITRIFICATION IN DUTCH HEATHLAND SOILS. I. NITRATE PRODUCTION IN UNDISTURBED SOILS

III TWO TYPES OF CHEMOLITHOTROPHIC NITRIFI-

IV NITRIFICATION IN DUTCH HEATHLAND SOILS. II.

V ACID-SENSITIVE, CHEMOLITHOTROPHIC NITRIFICATION IN A FERTILIZED, ACID HEATHLAND SOIL. I.GENERAL CHARACTERISTICS

VI ACID-SENSITIVE, CHEMOLITHOTROPHIC NITRIFICATION IN A FERTILIZED, ACID HEATHLAND SOIL. II.EFFECT OF ORGANIC N-COMPOUNDS

VII UREOLYTIC NITRIFICATION AT LOW $\mathrm{pH}$ BY NITROSOSPIRA SPEC.

REFERENCES

SUMMARY 

CHAPTER I

\section{INTRODUCTION}




\section{INTRODUCTION}

This thesis is the result of a study that was performed to obtain more knowledge of the occurrence and mechanism of nitrate production in Dutch heathland soils. The study deals mainly with the microbiological aspects of nitrification in these acid soils. This chapter gives a brief review of current knowledge of nitrification in soils with a low $\mathrm{pH}$.

The occurrence of nitrification in heathland soils directly affects the nitrogen dynamics of the heathland ecosystem because nitrate may be used by plants as a supplementary nitrogen source. Furthermore nitrate may be lost from the heathland soil either by leaching or denitrification. The following part of this chapter summarizes some of the information available on the nitrogen dynamics in heathlands.

\section{NITROGEN DYNAMICS IN HEATHLANDS}

Most of the Dutch heathlands are located on the nutrient-poor, acid, sandy soils in the central and eastern parts of the Netherlands. These heathlands are relicts of an old agricultural system called the 'potstal' system (De Smidt 1979). This system was operative from the 8th until the 19th century in Northwest European lowlands. The principle of the system was that agricultural soils were fertilized with nutrients supplied by the heath (De Smidt 1979). The 'potstal' system dissappeared with the use of industrial fertilizers. Most of the heathlands have also disappeared because they were transformed into arable fields or planted with pine trees. In the Netherlands the heath area has decreased from 600.000 ha in the early 19 th century to 42.000 ha in 1988 (De Smidt 1979; Van Gelder 1988).

Most of the remaining heathlands are situated in nature reserves. Management, e.g. sod-cutting and grazing, is required to maintain dwarf-shrub-dominated heathlands (Gimingham and De Smidt 1983; Van Gelder 1988). A management problem is the replacement by grasses of the dominant dwarf-shrubs, Calluna vulgaris on dry stands and Erica tetralix on wet stands (Van Gelder 1988). At present approximately $55 \%$ of the heathland area is partly or completely dominated by grass species e.g. Deschampsia flexuosa and Molinia caerulea (Van Gelder 1988).

The replacement of dwarf-shrubs by grasses is a spontaneous process. However, during the last two decades this replacement process is accelerating (Van Gils 1983). It was shown that the replacement of dwarf-shrubs by grasses coincides with a high availability of nitrogen for plant growth (Heil and Bruggink 1987; Berendse 1988). Hence, the development of a heathland vegetation is strongly affected by the supply of mineral nitrogen that can be taken up by plants.

The availability of mineral nitrogen in a heathland soil is determined by the input, the transformations and the output of nitrogen. The main source of nitrogen input in heathland ecosystems is atmospheric deposition of $\mathrm{NO}_{x}$ and $\mathrm{NH}_{x}$ (Gimingham 1972). Since the beginning of this century, more especially the last two 
decades, nitrogen deposition rates have increased considerably (Adema 1984). This increase can be attributed to the development of industry and traffic $\left(\mathrm{NO}_{x^{-}}\right.$ emissions) and the intensification of animal husbandry ( $\mathrm{NH}_{x}$-emissions). The rate of nitrogen deposition in pre-industrial times has been estimated to be 0.15 $4 \mathrm{~kg} \mathrm{~N} \mathrm{ha}^{-1} \mathrm{yr}^{-1}$ (Schneider and Bresser 1987). For the period 1980-1987 the mean annual nitrogen deposition in the Netherlands was approximately $42 \mathrm{~kg} \mathrm{~N} \mathrm{ha}^{-1} \mathrm{yr}^{-1}$ with almost equivalent contributions of $\mathrm{NH}_{x}$ and $\mathrm{NO}_{x}$ (Schneider and Bresser 1987, 1988). The mean annual nitrogen deposition on the heathlands is believed to be of the same order of magnitude although additional $\mathrm{NH}_{x}$-deposition in areas with high concentrations of livestock can result in much higher values (up to $90 \mathrm{~kg} \mathrm{~N}$ $\mathrm{ha}^{-1} \mathrm{yr}^{-1}$ ).

It is believed that nitrogen fixation is not an important source of nitrogen in heathlands unless leguminous shrubs e.g. Ulex spp. are present (Gimingham 1972). In most terrestrial ecosystems inputs by non-symbiotically, nitrogen-fixing microorganisms are in the range of $1-5 \mathrm{~kg} \mathrm{~N} \mathrm{ha}^{-1} \mathrm{yr}^{-1}$ (Boring et al. 1988).

The size and composition of the mineral nitrogen pool in the soil are determined by the nitrogen transformations which consist of uptake of mineral nitrogen by the plants (assimilation), uptake of mineral nitrogen by the microbial soil biomass (immobilization), liberation of ammonium from the organic nitrogen pool (ammonification), oxidation of ammonium (nitrification) and reduction of nitrate (denitrification and nitrate ammonification).

The amount of nitrogen that is transformed annually in a heathland soil depends greatly on the age, condition and composition of the vegetation (Heil 1984; Berendse 1988). Using core incubations in the field, it was shown that net nitrogen mineralization rates for Dutch heathland soils may increase from $0-10 \mathrm{~kg} \mathrm{~N}$ $\mathrm{ha}^{-1} \mathrm{yr}^{-1}$ during the first decade after the cutting of sods to as much as $130 \mathrm{~kg} \mathrm{~N} \mathrm{ha}^{-1} \mathrm{yr}^{-1}$ during the third to fifth decade (Berendse et al. 1987; Berendse 1988). The highest values of nitrogen mineralization were measured in grass-dominated heathland soils (Berendse 1988).

The increase in nitrogen mineralization coincides with the development of an organic layer (Berendse 1988). Measurements of potential nitrogen mineralization revealed that most of the mineral nitrogen is produced in the organic horizon (O) and in the upper mineral horizon (Ah) (Lache 1976; Vonk 1988). More precisely, within the organic horizon, net mineral nitrogen is produced in the layer of more or less decomposed material (FH) whereas in the litter layer nitrogen immobilization may predominate (Lache 1976; Berendse 1989).

The sole or main product of measurements of potential nitrogen mineralization was found to be ammonium in most dwarf-shrub dominated heathlands. This indicates that production of nitrate may be absent (Lache 1976 ; Bonneau 1980; Berendse 1988; Rozé 1988). In disturbed or mature dwarf-shrub heathlands and in grass-dominated heathland soils, nitrate production was found to be more important although ammonium was still the main product of potential nitrogen mineralization (Bonneau 1980; Vonk 1988). Although there are indications that nitrate production occurs in situ in heathland soils (Mulder 1988) estimates of rates of nitrate production in the field are few. 
There is also little known about the occurrence of nitrate reduction processes in heathland soils. It was shown that in principle denitrification can occur at the indigenous $\mathrm{pH}$ (Müller et al. 1980; Vonk 1988). Most nitrogen balance studies of heathland soils indicate that in situ denitrification is of minor importance because there is only a small loss of nitrogen from the system which appears to be the result of leaching (Matzner 1980; Rozé 1988). Berendse (1988) calculated for 2 Dutch heathland soils that, during a period of 30 years after the removal of sods, the annual increase in nitrogen ( $33 \mathrm{~kg} \mathrm{~N} \mathrm{ha}^{-1} \mathrm{yr}^{-1}$ ) was approximately the same as the mean annual deposition of nitrogen indicating that almost no nitrogen was lost from the system. However in the same study, it was shown that deposition of nitrogen exceeded nitrogen accumulation in a grass-dominated heathland soil which was probably due to leaching or denitrification.

The increase of atmospheric deposition of nitrogen in the Netherlands probably affects the nitrogen transformations in heathland soils not only by increasing the mineral nitrogen pool, but also by increasing the production of plant litter and by changing its composition (Berendse 1988). If the result of this means that mineral nitrogen is no longer limiting growth of plants and heteroptrophic micro-organisms than processes such as nitrification and denitrification may have become more important.

\section{NITRATE PRODUCTION IN ACID SOILS}

Since the beginning of this century, soil scientists have occasionally reported the occurrence of nitrate production in acid soils (Fred and Graul 1916; Kaila 1954; Weber and Gainey 1962; Gerlach 1973). Yet, not much attention was paid to the production of nitrate in acid soils until it became evident that this process may contribute to environmental problems:

-(1) Acidification. It has been shown that nitrification can be a major source of acidification in acid forest soils (Van Miegroet and Cole 1984,1985; Van Breemen et al. 1987). Acidification of forest soils gives rise to both increased concentrations of aluminum ions in the soil solution and leaching of important nutrients $(\mathrm{K}, \mathrm{Mg}, \mathrm{Ca})$ from the forest floor (Likens et al. 1969; Mulder 1988). This may have a negative impact on the viability of trees.

-(2) Leaching of nitrate. Although pollution of the groundwater with nitrate was believed to be a problem in agricultural areas only, it is becoming more and more evident that in many acid forest soils nitrate concentrations in the groundwater are increasing (Keeney 1986; Schneider and Bresser 1988; Mulder 1988 ). As ground-water is a source of drinking-water this is a matter of much concern.

-(3) $\mathbf{N}_{2} \mathbf{O}$-production. It has been observed that nitrate production is accompanied by a small production of $\mathrm{N}_{2} \mathrm{O}(-0.1 \%)$ (Sahrawat and Keeney 1986). $\mathrm{N}_{2} \mathrm{O}$ is involved in promoting the destruction of the stratospheric ozone layer (Crutzen 1981). Studies on forest soils suggest that fluxes of $\mathrm{N}_{2} \mathrm{O}$ from these soils may be of a magnitude similar to those from agricultural soils (Sahrawat and Keeney 1986). 
The studies on nitrate production in acid soils are mainly focused on 3 topics:

1. Measurements of the potential - and actual nitrate production

2. Regulation of the nitrate production

3. The nitrifying micro-organisms

\section{Measurements of the potential - and actual nitrate production}

It is not possible to measure actual nitrate production at present. All methods that have up till now been developed somehow disturb the bio-dynamics of the soil including the nitrate-producing and -consuming processes. Almost all measurements that are claimed to measure the actual nitrate production are in fact approximations of the actual net nitrate production. The best methods, so far, are those that are quick and disturb the soil stucture as little as possible. Techniques that seem to fullfill this criteria the best, are measurements of nitrate production in cores that are incubated in the field (Raison et al. 1987). These techniques give an estimate of in situ net nitrate production over a prolonged period. Measurements are made at regular intervals. Recent publications on sensitive nitrate measurements (Lensi et al. 1985; Christensen and Tiedje 1988) may make it possible to reduce the intervals that are needed to determine the formation of nitrate. Furthermore the ${ }^{15} \mathrm{NO}_{3}$ dilution technique which was developed for flooded soils by Watanabe et al. (1981) may be used for unsaturated soils (Jackson et al. 1989). The advantage of this technique is that it gives an estimate of the gross nitrate production.

The potential net nitrate production in acid soils is measured in homogenized soil samples with or without substrate amendment (Weber and Gainey 1962; Gerlach 1973; Robertson 1982ab; Lensi et al. 1986). The samples are incubated either in the field or in the laboratory. Another way of measuring potential nitrate production is done by determing the amount of nitrate that is formed in perfused soil columns or in soil suspensions (Reddy 1982; Schmidt and Belser 1982; Killham 1987). The interpretation of a particular potential nitrate production measurement depends on the method used. For instance, quick measurements are believed to show the maximum activity of the nitrifying population that was present at the time of sampling (Schmidt and Belser 1982).

\section{Regulation of the nitrate production}

Factors that may have an impact on nitrate production in acid soils are $\mathrm{pH}$, availability of ammonium, moisture, temperature and allelochemical inhibitors. The relationship between soil-pH and nitrate production is far from clear. In agricultural soils and in soils from experimental fertilization plots, potential net nitrate production is often found to be positively correlated with soil $\mathrm{pH}$ (Dancer et al. 1973; Nyborg and Hoyt 1978; Gilmour 1984). Some investigators have predicted a 
lower pH-limit of 4 for nitrate production in agricultural soils (Dancer et al. 1973; Gilmour 1984). However, with forest soils no relationship was found between $\mathrm{pH}$ and potential net nitrate production (Heilman 1974; Robertson 1982a). Even in forest soils of $\mathrm{pH} 3$ nitrate production occured (Robertson 1982a). Soil pH may directly affect nitrate production by limiting the activities of the nitrifying micro-organisms or indirectly by limiting the ammonification and thus the availability of ammonium (Robertson 1982a). Also, the dissolution of aluminum-ions and the availabilty of phosphate, which both may affect nitrate production, are dependent on the soil $\mathrm{pH}$ (Brar and Giddens 1968; Purchase 1974; Pastor et al. 1984).

Ammonium-availability is believed to be the most important regulator of nitrate production in many acid forest soils (Robertson 1982ab; Vitousek et al. 1982; Christensen and MacAller 1985; White and Gosz 1987). In the soils studied nitrogen mineralization is the main source of ammonium. However, in areas in Western-Europe atmospheric deposits are also important sources of ammonium due to high concentrations of livestock. It will be of interest to know whether the availability of ammonium is still an important regulating factor of nitrate production in acid forest soils that are exposed to high levels of ammonium deposition.

Similarly to the $\mathrm{pH}$, soil moisture content and soil temperature may both have a direct and an indirect effect on nitrate production as ammonification is also dependent on these factors (Clarholm et al. 1981). Both factors are thought to play an important role in the seasonal variation of nitrate production in acid soils (Davy and Taylor 1974). The optimum temperature for nitrate production in soils varies with the climate of the region, it may range from $15-35{ }^{\circ} \mathrm{C}$ (Malhi and McGill 1982). The optimum temperature for nitrate production in a Dutch acid oak-beech soil was $25{ }^{\circ} \mathrm{C}$, whereas nitrate production was completely inhibited at $30{ }^{\circ} \mathrm{C}$ (Emmer and Tietema submitted). There are only few data on the impact of soil moisture on nitrate formation in acid soils. Matson and Vitousek (1981) observed an increase of nitrate production in an acid forest soil when the soil moisture content was increased from 15 to 35 per cent. It is expected that nitrate production in water-saturated acid soils will be limited by the supply of oxygen as is the case with other soils (Beck 1979).

Allelochemical inhibition, especially inhibition by polyphenols, was reported to be the cause of low nitrate production in a number of acid soils (Olsen and Reiners 1983; Rice 1984). However, the interpretation of the experiments showing allelochemical inhibition has been criticized (Robertson 1982b).

\section{The nitrifying micro-organisms}

In most neutral and alkaline soils nitrate formation is caused by bacteria belonging to the family Nitrobacteriaceae (Watson et al. 1989). These bacteria are called chemolithotrophs because they are able to use the oxidation of inorganic (nitrogen) compounds as a source of energy. Based on their oxidation capacity, two groups of bacteria within the family Nitrobacteraceae are distinguished, namely ammonium- and nitrite-oxidizing bacteria. 
Ammonium-oxidizing bacteria perform the following oxidation:

$$
\mathrm{NH}_{4}^{+}+3 / 2 \mathrm{O}_{2}-\cdots \mathrm{NO}_{2}^{-}+\mathrm{H}_{2} \mathrm{O}+2 \mathrm{H}^{+}
$$

In soils, different genera of chemolithotrophic ammonium-oxidizing bacteria may be active e.g. Nitrosomonas, Nitrosospira, Nitrosolobus and Nitrosovibrio (Schmidt 1982).

Nitrite is further oxidized by nitrite-oxidizing bacteria:

$$
\mathrm{NO}_{2}^{-}+1 / 2 \mathrm{O}_{2}-\cdots \mathrm{NO}_{3}^{-}
$$

In soils, Nitrobacter seems to be the only genus performing the chemolithotrophic oxidation of nitrite (Schmidt 1982).

Both groups of chemolithotrophic nitrifying bacteria can use $\mathrm{CO}_{2}$ as the sole source of carbon (Wood 1986). Therefore these bacteria are also called chemolitho-autotrophs or chemo-autotrophs. Nitrate production by these bacteria is called chemolithotrophic, chemoautotrophic or autotrophic nitrification. For more detailed information concerning the taxonomy, physiology and biochemistry of chemolithotrophic nitrification the reader is referred to the reviews by Focht and Verstraete (1977), Belser (1979), Schmidt (1982), Bock et al. (1986), Wood (1986), Kuenen and Robertson (1987), Bédard and Knowles (1989), Watson et al. (1989).

The activity of chemolithotrophic nitrifying bacteria is greatly affected by the $\mathrm{pH}$ of the environment. Lower $\mathrm{pH}$-limits of $5.5 \cdot 6.0$ have been reported for the activity of both ammonium- and nitrite-oxidizing bacteria in batch cultures (Focht and Verstraete 1977; Watson et al. 1982; Keen and Prosser 1987). Surprisingly, also chemolithotrophic nitrifying bacteria that have been enriched or isolated from acid soils show the same sensitivity towards acidity (Weber and Gainey 1962; Hankinson and Schmidt 1984; Martikainen and Nurmiaho-Lassila 1985). However, recently a chemolithotrophic nitrite-oxidizing strain that was able to produce nitrate at $\mathrm{pH} 4$ has been isolated from an acid forest soil (Hankinson and Schmidt 1988). The inability of chemolithotrophic nitrifying bacteria to be active at low $\mathrm{pH}$ has been ascribed to toxicity of $\mathrm{HNO}_{2}$ (Focht and Verstraete 1977). The concentration of $\mathrm{HNO}_{2}$ is dependent on both the $\mathrm{pH}$ and the nitrite concentration.

The sensitivity towards acidity of chemolithotrophic nitrifying bacteria has raised questions about their role in producing nitrate in acid soils. It was proposed that acid-sensitive chemolithotrophs may be active in micro-sites that are less acid than the surrounding soil (Overrein 1967; Hankinson and Schmidt 1984,1988). Such micro-sites may be the result of local intensive ammonification (Kaila 1954). In this respect, the role of soil animals may be important as it was shown that the nitrifying activity was very high in casts of earthworms in a beech forest (Scheu 1987). Still, it can be questioned whether the activity of acid-sensitive chemolithotrophic nitrifiers is completely dependent on the occurrence of micro-sites of neutral $\mathrm{pH}$, because the 
sensitivity of these bacteria to acidity in batch cultures may be different to that in soils. Keen and Prosser (1987) showed that freely suspended cells of Nitrobacter were not active below $\mathrm{pH} 5.5$, whereas attached cells that were covered in extracellular slime, oxidized nitrite at $\mathrm{pH} 4.5$.

Nitrate production in acid soils that seem to lack chemolithotrophic nitrifying bacteria, as quantified by the Most Probable Number technique, is often believed to be the result of chemo-organotrophic micro-organisms (Ishaque and Cornfield 1976; Tate III 1977; Lang and Jagnow 1986; Kuenen and Robertson 1987). However, this interpretation is questionable as the Most Probable Number technique, has been developed for the enumeration of chemolithotrophic nitrifiers in agricultural soils of neutral pH (Schmidt and Belser 1982). Therefore, it cannot be excluded that nitrate production in acid soils is caused by chemolithotrophic nitrifiers with unknown properties that cannot be detected using the standard Most Probable Number technique.

Still, it is obvious that many chemo-organotrophic bacteria and fungi, that have been isolated from acid soils, are able to oxidize ammonium or organic- $\mathrm{N}$ compounds to nitrite or nitrate (Focht and Verstraete 1977; Johnsrud 1978; Lettl 1985). Hence, nitrate production by chemo-organotrophic micro-organisms may be important in acid soils. Thusfar, growth of all chemo-organotrophic nitrifying micro-organisms was shown to be completely dependent on the metabolism of organic compounds (Focht and Verstraete 1977; Killham 1986; Kuenen and Robertson 1987). The production of nitrite or nitrate by chemo-organotrophic micro-organisms is called heterotrophic nitrification. For further information concerning the physiology and biochemistry of heterotrophic nitrifiers the reader is referred to Focht and Verstraete (1977), Killham (1986), Kuenen and Robertson (1987), Robertson (1988).

The nitrifying activity of many chemo-organotrophs was shown to be acid-sensitive in batch cultures (Johnsrud 1978). Therefore, nitrifying activities of many of these micro-organisms may also be restricted to micro-sites of neutral $\mathrm{pH}$ (Stroo et al. 1986). However, some chemo-organotrophic bacteria and fungi have been reported to produce nitrate in media of $\mathrm{pH}<5$ (Lettl 1985; Stroo et al. 1986; Lang and Jagnow 1986).

Specific inhibitors of chemolithotrophic ammonium-oxidation are used to determine the nature of nitrification in acid soils (Hynes and Knowles 1982; Schimel et al. 1984; Killham 1987). Nitrapyrin and acetylene are mostly used for this purpose. Both compounds are claimed to be specific inhibitors of the ammonia mono-oxygenase of chemolithotrophic ammonium-oxidizing bacteria (Goring 1962; Hynes and Knowles 1982; Killham 1986). Using these inhibitors it was indicated that either chemolithotrophic or chemo-organotrophic micro-organisms may be the predominant nitrifiers in acid soils (Schimel et al. 1984; Kreitinger et al. 1985; Adams 1986a; Weier and Gilliam 1986; Killham 1987). The factors that determine whether nitrification is mainly chemolithotrophic or chemo-organotrophic are not known.

There has been critisism on the use of inhibitors since it is known that they were not as specific as was claimed (Namir et al. 1986; Kuenen and Robertson 1987). It was shown that the ammonia-oxidizing enzyme of Thiosphaera pantotropha, a 
bacterium that is able to nitrify and denitrify simultaneously, closely resembled the ammonia mono-oxygenase of chemolithotrophic ammonium-oxidizing bacteria (Robertson and Kuenen 1988). Hence, it may be possible that some of the chemo-organotrophic nitrifiers that are present in acid soils also possess an ammonia-oxidizing enzyme that is inhibited by acetylene and nitrapyrin. A similar problem occurs when active methanotrophs are present in an acid soil, as it was shown that ammonium-oxidation by these bacteria is inhibited by acetylene and nitrapyrin (Bédard and Knowles 1989). Hence, the determination of the nature of nitrification in acid soils cannot depend entirely on the outcome of inhibition experiments. Additional information to determine the predominant nature of nitrification may be given by determing the relationship between the production of $\mathrm{CO}_{2}$ and nitrate (Kreitinger et al. 1985). An increase in nitrate production, caused by chemo-organotrophic micro-organisms, needs to be attended by an increase in $\mathrm{CO}_{2}$ production, whereas, in the case of predominant chemolithotrophic nitrification, it is expected to be accompagnied by an increase in $\mathrm{CO}_{2}$ consumption.

Stimulation of the nitrate production in acid soils by the addition of organic-N compounds has often been interpreted as a result of the activity of chemo-organotrophic nitrifiers (Ishaque and Cornfield 1976; Van de Dijk and Troelstra 1980; Adams 1986a). However, this interpretation can be questioned because ammonification of the added compounds may result in an increase of micro-sites suitable for the activity of acid-sensitive chemolithotrophic nitrifiers.

It will be difficult or even impossible to prove conclusively that nitrate production in acid soils is caused exclusively by either chemolithotrophic or chemo-organotrophic nitrifiers. It is however very important to be able to distinguish these two types of nitrification, because nitrate production by chemo-organotrophic micro-organisms is expected to be limited by the supply of degradable carbon compounds, whereas nitrate production by chemolithotrophs may be limited by the supply of ammonium. Therefore the amount of nitrate that can be produced in acid soils may be greatly dependent on the nature of nitrification. 


\section{OUTLINE OF THIS THESIS}

In the first part of this Chapter it was suggested that production of nitrate may have become important in Dutch heathland soils because of the increase in atmospheric deposition of nitrogen compounds. Therefore, a study on the occurrence and regulation of nitrate production in 17 Dutch heathland locations was performed. The results of this study are presented in the Chapters 2 and 4.

It appeared that nitrate production occurred in many heathland soils. Therefore, it became of interest to know which micro-organisms are responsible for the nitrate production in these acid soils. The nature of nitrification, chemolithotropic or chemo-organotrophic, and the activity of the nitrifying micro-organisms at different $\mathrm{pH}$ values were studied for 2 heathland soils (Chapter 3 ). Evidence is given that either acid-sensitive - or, previously unknown, acid-tolerant chemolithotrophic bacteria were the main nitrifying micro-organisms in the soils studied. A study on the distribution of both types of chemolithotropic nitrification in Dutch heathland soils is presented in Chapter 4.

The presence of acid-sensitive, chemolithotrophic, nitrifying bacteria in heathland soils gave rise to the question of how these bacteria manage to be active in acid soils. This was studied using a fertilized, acid heathland soil that apparently contained only acid-sensitive, chemolithotrophic nitrifiers as can be seen in Chapter 5. In this Chapter, a relationship between nitrification and ammonification at low $\mathrm{pH}$ is proposed to explain the production of nitrate by acid-sensitive, nitrifying bacteria under acid conditions. The proposed relationship between ammonification and acid-sensitive nitrification was further studied by testing the effect of various organic $\mathrm{N}$-compounds on the nitrate production in suspensions at low $\mathrm{pH}$. The results of this study are presented in Chapter 6. It appeared that acidsensitive nitrification was specifically stimulated at low $\mathrm{pH}$ by the addition of urea. The effect of urea on the activity of acid-sensitive nitrifiers at low $\mathrm{pH}$ has also been studied using pure cultures of nitrifying strains (Chapters 6 and 7).

Finally, the properties of the chemolithotrophic nitrifying bacteria in heathland soils are discussed with respect to in situ nitrate production (Chapter 8). 


\section{CHAPTER II}

NITRIFICATION IN DUTCH HEATHLAND SOILS. I. NITRATE PRODUCTION IN UNDISTURBED SOIL CORES

S.R. TROELSTRA, R. WAGENAAR AND W. DE BOER

Submitted for publication to Plant and Soil 


\begin{abstract}
A survey was conducted over a range of 17 Dutch heathland locations, subdivided into 41 sites dominated by either dwarf-shrubs (Calluna vulgaris or Erica tetralix) or grass species (Deschampsia flexuosa or Molinia caenulea). Among sites dominated by the same plant species relatively little differences in general soil properties were observed. The $\mathrm{P}$ status of Deschampsia sites was relatively high and nitrate-N concentrations in the $0-10 \mathrm{~cm}$ layer ( $\mathrm{FH}$ included) were relatively high at the grassdominated sites. Ammonium- $\mathrm{N}$ concentrations reached very high levels, at sites with a dead or degenerating dwarf-shrub vegetation.

Net production of nitrate was observed during incubation of intact $0-10 \mathrm{~cm}$ soil cores (FH-layer included) in the laboratory for all sites, even though in some instances no nitrate was initially measured. Generally, cores from Deschampsia-sites showed a high nitrification rate. The net production of nitrate in cores was highly significantly correlated with net $\mathrm{N}$ mineralization $(\mathrm{R}=0.69 ; \mathrm{P}<0.001$ ), being a reasonable predictor of nitrification in a simple regression model $\left(\mathbf{R}^{2}=0.47\right.$; $\mathrm{P}<0.001$ ). Net nitrification was also significantly correlated with the amount of nitrate- $N$ initially present at the start of the growing season $(R=0.65 ; P<0.001)$ and with the labile organic $P$ content of the soil $(R=0.65 ; P<0.001)$, but not with the soil $\mathrm{pH}$. By including initial nitrate- $\mathrm{N}$ and labile organic $\mathrm{P}$, together with net $\mathrm{N}$ mineralization and $\mathrm{pH}$, in a multiple regression model, net nitrate production in cores could be predicted with a much higher precision $\left(\mathrm{R}^{2}=0.75 ; \mathrm{P}<0.001\right)$.
\end{abstract}

\title{
INTRODUCTION
}

In natural ecosystems where the bulk of the total soil $\mathrm{N}$ is present in organic form, the important processes of the $\mathrm{N}$ cycle are $\mathrm{N}_{2}$-fixation, ammonification, nitrification, uptake by plants and immobilization by micro-organisms, denitrification and leaching of nitrate (Campbell, 1978; Jansson and Persson, 1982; Schmidt, 1982). Whereas in tropical soils temperature may have a predominant influence on the process of nitrification, in soils of the temperate regions, factors such as $\mathrm{pH}$, substrate availability, and aeration are essential. Generally, nitrification takes place within more limited $\mathrm{pH}$, moisture and temperature ranges than ammonification (Schmidt, 1982), but nitrification may still occur at relatively. low temperatures and also in acid soils (e.g. Davy and Taylor, 1974; Gerlach, 1973; Runge, 1983). No relationship could be established between $\mathrm{pH}$ and potential net nitrification in forest soils (Robertson, 1982a). In some of these soils nitrate production was observed to occur at a $\mathrm{pH}$ as low as 3 .

Most heathlands in the Netherlands are located on the acid, nutrient-poor sandy soils in the Centre and East. With regard to the nitrogen dynamics of these heathland soils, the occurrence of nitrification is of interest because (1) nitrate may be utilized by the heathland vegetation as a supplementary source of nitrogen; (2) in 
contrast to ammonium, nitrate may be lost from the system due to leaching and/or denitrification; and (3) nitrification may contribute to the overall process of soil acidification. The last point may be of particular importance in the Netherlands, where atmospheric deposition rates of ammonium have dramatically increased over the past decades due to an explosive rise of intensive animal husbandry. It was shown that nitrification of atmospheric ammonium is an important source of soil acidification in Dutch forest soils (Van Breemen et al. 1982). The increase of atmospheric input of mineral $\mathrm{N}$ is also believed to affect the composition of the heathland vegetation. It was shown that under conditions of higher nitrogen availablilty for plants, a dwarf-shrub-dominated heathland vegetation can be replaced by a vegetation dominated by grasses (Heil and Diemont, 1983). Under these conditions also net nitrate production may have become more important. However, information on nitrification rates in acid heathland soils is rather scanty and most studies emphasize the role of ammonium as the main product of nitrogen mineralization (Lache, 1976; Rozé, 1988; Vonk, 1988). Therefore, it was decided to carry out a survey of a large number of heathland locations in the Netherlands with the object of assessing the ranges of rates of $\mathrm{N}$-mineralization and nitrification, in sites dominated by either grass species (Deschampsia flexuosa or Molinia caenulea) or dwarf-shrubs (Calluna vulgaris or Erica tetralix). This Chapter deals with the net production of nitrate in undisturbed soil cores, whereas Chapter 4 will focus on characteristics of nitrification in the soils studied.

\section{MATERIAL AND METHODS}

\section{Locations and sampling procedures}

Seventeen heathland locations were selected in the central and eastern parts of the Netherlands (Fig. 1). A total of 41 sites was sampled during early spring 1988 (period March 21-30). All sampling sites were dominated by one plant species: Calluna vulgaris $(\mathrm{n}=12)$, Erica tetralix $(\mathrm{n}=10)$, Deschampsia flexuosa $(\mathrm{n}=9)$, and Molinia caenulea $(n=10)$. Samples were always collected from a representative area of $50-100 \mathrm{~m}^{2}$. Four successive layers were sampled, viz. 0-5 (FH included), 5-10, $10-15$, and $15-25 \mathrm{~cm}$, and samples were composited per site and per layer for the analysis of general site characteristics. After drying $\left(35^{\circ} \mathrm{C}\right)$ for at least one week and sieving $(2 \mathrm{~mm})$, bulk samples were mechanically subdivided (Retsch subsampler type PTZ) and part of the sample was ground in a mortar mill. Analyses were done as required on either ground or unground samples.

Separate samples were taken in duplicate for the determination of moisture and $\mathrm{pH}$ on fresh material. In addition, per site intact $0-10 \mathrm{~cm}$ soil cores were collected in duplicate for determination of initial mineral $N$ concentrations $(\phi=1.3 \mathrm{~cm})$ and in 5-fold for incubation in the laboratory $(\phi=3 \mathrm{~cm})$. Samples for the determination of initial mineral $\mathrm{N}$ concentrations were collected in pre-weighed bottles, transported in an insulated container to the laboratory, and freshly analyzed without any further pretreatment; these samples were kept at $4{ }^{\circ} \mathrm{C}$ until they were analyzed. 


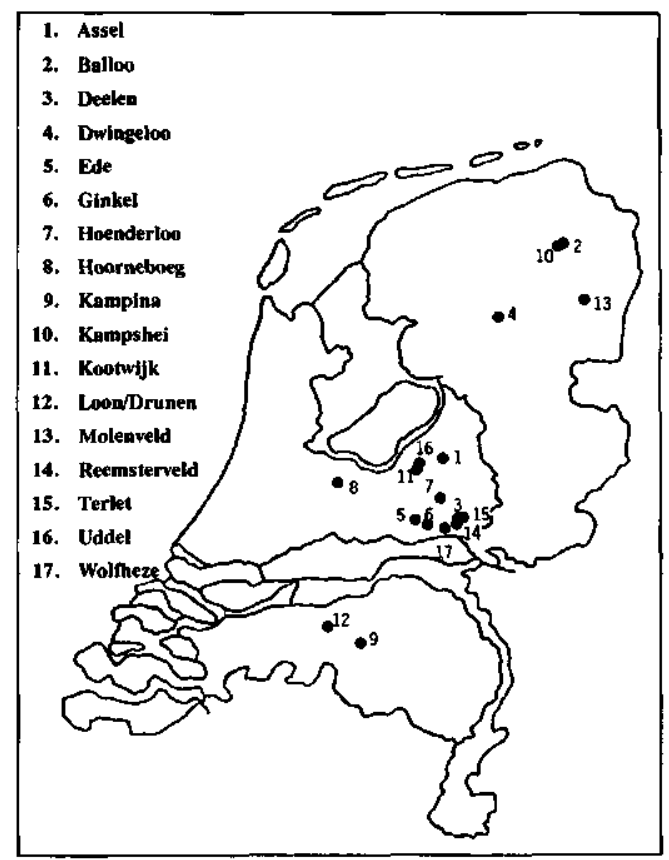

Fig. 1. Location of sampling sites in the Netherlands

\section{Incubation experiment}

Intact $0-10 \mathrm{~cm}$ cores were put in polypropylene centrifuge tubes, transported to the laboratory in an insulated container, and incubated aerobically at $20^{\circ} \mathrm{C}$ without adjustment of the moisture content for a total period of 100 days. Tubes were incubated on the same day of sampling and stoppered in such a way that water loss was minimized but gas exchange could occur via a nylon gauze $(20 \mu)$ held by an open inner lid and covered by a perforated outer lid. A reservoir with deionized water at the bottom of the incubator ensured a high relative humidity. Following the incubation, the cores were extracted with $2 \mathrm{M} \mathrm{KCl}$ (soil/solution ratio 1:5) and the extracts were analyzed for nitrate and ammonium. Net mineralization and nitrification were calculated by subtracting the amount of mineral $\mathrm{N}$ present initially.

\section{Analytical techniques}

The $\mathrm{pH}$ was measured in 1:2.5 or (0-5 cm depth) 1:5 (dry) soil:water suspensions. The moisture content of fresh soil samples was determined as weight-loss after overnight drying at $105{ }^{\circ} \mathrm{C}$. Organic $\mathrm{C}$ was determined using a modified Mebius procedure (Nelson and Sommers, 1982). Total $\mathrm{N}$ and total $\mathrm{P}$ were measured colorimetrically following digestion with a mixture of $\mathrm{H}_{2} \mathrm{SO}_{4} \mathrm{Se}$ and salicylic acid (Novozamsky et al., 1984). Total organic P was determined by means of an ignition method (Saunders and Williams, 1955). Olsen-P and labile organic $P$ were 
determined in $0.5 \mathrm{M} \mathrm{NaHCO}$ extracts (w/v 1:20; Bowman and Cole, 1978; Olsen $e$ t al., 1954; Watanabe and Olsen, 1965). Exchangeable $\mathrm{K}, \mathrm{Na}$, and $\mathrm{Mg}$ were measured in neutral ammonium acetate extracts ( $w / v$ 1:25) by atomic absorption spectrophotometry. Exchangeable $\mathrm{Al}$ was determined in $1 \mathrm{M} \mathrm{KCl}$ extracts. Extractable $\mathrm{Fe}$ and $\mathrm{Al}$ were measured by extraction with ammonium oxalate/oxalic acid at $\mathrm{pH} 3$ (Houba et al. 1985). Fe and $\mathrm{Al}$ in the extracts were, respectively, determined by atomic absorption and by a colorimetric procedure using haematoxylin (Dalal, 1972). Ammonium and nitrate concentrations in $2 \mathrm{M} \mathrm{KCl}$ extracts were determined using a Technicon autoanalyzer.

Only in some instances, results are expressed on a dry weight basis. As the expression of the results on a soil volume basis is preferred from an ecological point of view, bulk density estimates were used to express parameters in terms of a standard volume or on an areal basis $\left(\right.$ per $\left.\mathrm{m}^{2}\right)$.

\section{Statistical analyses}

Soil layers originating from the same cores are dependent on each other, data were therefore, always analyzed per depth increment in a one-way analysis of variance with dominant plant species as factor and locations as replicates. If necessary, $\log$ or sqrt transformations were applied to data sets to establish homogeneity of variances. Tukey's test was used at the $5 \%$ probability level to identify significant differences between means.

Analyses of variance, correlations and regressions were performed using STATISTIX (Anon., 1987) or SPSS (Norusis, 1986) procedures.

\section{RESULTS}

\section{General soil characteristics of heathlands}

General soil characteristics are presented and discussed in the appendix of this thesis.

\section{Net nitrogen mineralization and nitrification in undisturbed cores}

The moisture content of the cores at sampling varied considerably between sites, although not significantly between plant species (Table 1 ). However, the generally wetter condition of the Erica and Molinia sites was evident: 36 per cent soil water compared to 28 per cent for Calluna and Deschampsia sites (Table 1).

Determinations of initial mineral nitrogen at almost all sites showed distinctly higher concentrations of ammonium- $\mathrm{N}$ than of nitrate- $\mathrm{N}$, in particular at the dwarfshrub sites, the ammonium concentrations becoming excessively high in the absence of a vigorous vegetation (Table 1; sites with degenerating plants); the one exception with initially more nitrate- $\mathrm{N}$ than ammonium- $\mathrm{N}$ was the Molina site at Reemsterveld. Mean nitrate concentrations at sampling were 5 to 10 times higher at sites dominated by grasses than at those dominated by dwarf-shrubs (Table 1). 
Table 1. Moisture, total $N$ content and mineral $N$ concentrations at sampling and mineralization/nitrification following the incubation of undisturbed soll cores collected at 17 heathland locations according to dominant plant species (Calluna vulgaris, Erica tetralix, Deschampsia flexuosa or Molinia caerulea. All data refer to the 0-10 cm depth (FH included).

\begin{tabular}{|c|c|c|c|c|c|c|}
\hline \multirow[t]{3}{*}{ Location } & \multirow{3}{*}{$\begin{array}{c}\text { Moisture } \\
(\%)^{+}\end{array}$} & \multirow{3}{*}{$\begin{array}{l}\text { Total N } \\
\left(\mathrm{g} / \mathrm{m}^{2}\right)\end{array}$} & \multicolumn{2}{|c|}{ Initial mineral $\mathbf{N}$} & \multicolumn{2}{|c|}{ Net mineralization/nitrification } \\
\hline & & & $\mathrm{NH}_{4}^{+}-\mathrm{N} \quad \mathrm{I}$ & $\mathrm{NO}_{3}^{-} \cdot \mathrm{N}$ & $\left(\mathrm{NH}_{4}+\mathrm{NO}_{3}\right)^{-\mathrm{N}}$ & $\mathrm{N} \quad \mathrm{NO}_{3}^{-}-\mathrm{N}$ \\
\hline & & & $\left(--\mathrm{mg} / \mathrm{m}^{2}\right.$ & $2--)$ & $\left(-\cdots \mathrm{mg} / \mathrm{m}^{2} \mathrm{p}\right.$ & per week - -) \\
\hline \multicolumn{7}{|l|}{ Calluna locations } \\
\hline Assel & 36 & 112 & 48 & 1 & 555 & 80 \\
\hline Dwingeloo* & 27 & 207 & 3337 & 44 & 661 & 62 \\
\hline Ede & 24 & 210 & 980 & 32 & 587 & 107 \\
\hline Ginkel & 23 & 231 & 530 & 81 & 768 & 134 \\
\hline Hoorneboeg* & 23 & 187 & 845 & 3 & 553 & 22 \\
\hline Kampina 1 & 32 & 155 & 219 & 1 & 205 & 8 \\
\hline Kampina 2 & 24 & 117 & 575 & 148 & 501 & 102 \\
\hline Loon/Drunen & 20 & 176 & 296 & 0 & 75 & 10 \\
\hline Molenveld & 30 & 51 & 144 & 0 & 363 & 12 \\
\hline Reemsterveid* & 42 & 222 & 7809 & 7 & 381 & 57 \\
\hline Terlet & 17 & 287 & 910 & 106 & 681 & 156 \\
\hline Wolfheze* & 31 & 286 & 2615 & 19 & 761 & 151 \\
\hline \multicolumn{7}{|l|}{ Erica-locations } \\
\hline Assel & 43 & 209 & 1146 & $\mathbf{0}$ & 578 & 17 \\
\hline Balloo & 29 & 208 & 131 & 0 & 865 & 75 \\
\hline Deelen & 46 & 179 & 513 & 1 & 548 & 11 \\
\hline Dwingeloo* & 34 & 202 & 4425 & 13 & 354 & 45 \\
\hline Hoenderloo & 30 & 152 & 835 & 1 & 628 & 48 \\
\hline Kampina & 36 & 183 & 985 & 168 & 620 & 133 \\
\hline Kampshei & 37 & 266 & 443 & 0 & 632 & 30 \\
\hline Kootwijk & 31 & 209 & 972 & 18 & 600 & 16 \\
\hline Molenveld & 32 & 268 & 156 & 15 & 386 & 11 \\
\hline Uddel & 38 & 227 & 36 & 3 & 483 & 12 \\
\hline \multicolumn{7}{|c|}{ Deschampsia-locations } \\
\hline Ede & 30 & 101 & 767 & 525 & 865 & 173 \\
\hline Ginkel & 29 & 232 & 486 & 211 & 852 & 232 \\
\hline Hoorneboeg & 19 & 213 & 429 & 1 & 688 & 35 \\
\hline Kootwijk & 36 & 262 & 2043 & 125 & 840 & 187 \\
\hline Molenveld & 32 & 225 & 1381 & 103 & 847 & 84 \\
\hline Reemsterveld & 35 & 111 & 681 & 248 & 751 & 143 \\
\hline Terlet & 15 & 214 & 427 & 364 & 699 & 178 \\
\hline Wolfheze 1 & 31 & 238 & 713 & 56 & 683 & 170 \\
\hline Wolfheze 2 & 21 & 251 & 950 & 201 & 964 & 275 \\
\hline
\end{tabular}


Table 1. (continued)

\begin{tabular}{|c|c|c|c|c|c|c|}
\hline \multirow[t]{2}{*}{ Location } & \multirow{2}{*}{$\begin{array}{c}\text { Moisture } \\
(\%)^{+}\end{array}$} & \multirow{2}{*}{$\begin{array}{l}\text { Total N } \\
\left(\mathrm{g} / \mathrm{m}^{2}\right)\end{array}$} & \multicolumn{2}{|c|}{ Initial mineral $\mathbf{N}$} & \multicolumn{2}{|c|}{ Net mineralization/nitrification } \\
\hline & & & $\begin{array}{l}\mathrm{NH}_{4}^{+} \cdot \mathrm{N} \quad \mathrm{N} \\
\left(-\mathrm{mg} / \mathrm{m}^{2}\right.\end{array}$ & $\begin{array}{l}\mathrm{NO}_{3} \cdot-\mathrm{N} \\
=--)\end{array}$ & $\begin{array}{c}\left(\mathrm{NH}_{4}+\mathrm{NO}_{3}\right)^{-\mathrm{N}} \\
\left(-\mathrm{mg} / \mathrm{m}^{2} \mathrm{pe}\right.\end{array}$ & $\begin{array}{c}\mathrm{NO}_{3}-\mathrm{N} \\
\text { er week - -) }\end{array}$ \\
\hline \multicolumn{7}{|c|}{ Molinia-locations } \\
\hline Assel & 37 & 76 & 836 & 351 & 734 & 159 \\
\hline Balloo & 33 & 248 & 714 & 4 & 448 & 49 \\
\hline Dwingeloo & 24 & 300 & 946 & 19 & 531 & 63 \\
\hline Ede & 26 & 192 & 656 & 376 & 606 & 156 \\
\hline Kampina & 30 & 250 & 381 & 188 & 393 & 87 \\
\hline Kampshei & 54 & 173 & 604 & 9 & 509 & 8 \\
\hline Kootwijk & 26 & 290 & 549 & 271 & 669 & 140 \\
\hline Reemsterveld & 30 & 247 & 274 & 473 & 868 & 97 \\
\hline Terlet & 12 & 276 & 1101 & 17 & 437 & 55 \\
\hline Uddel & 56 & 161 & 402 & 0 & 562 & 18 \\
\hline
\end{tabular}

+ (wet weight - dry weight)/wet weight $\times 100$

* dead/degenerating vegetation

In the undisturbed $0-10 \mathrm{~cm}$ cores after the 100-day-jncubation period always more ammonium-N than nitrate-N was produced (Table 1). Mean net nitrogen mineralization rates were approximately equal for Calluna, Erica, and Molinia sites (0.5-0.6 g mineral- $\mathrm{N} / \mathrm{m}^{2}$ per week) and significantly lower than those observed for Deschampsia sites ( $0.8 \mathrm{~g}$ mineral- $\mathrm{N} / \mathrm{m}^{2}$ per week). The same picture emerged for net nitrate production: rates of $0.04-0.08 \mathrm{~g}$ nitrate- $\mathrm{N} / \mathrm{m}^{2}$ per week (Calluna, Erica and Molinia sites) were significantly lower than $0.16 \mathrm{~g}$ nitrate- $\mathrm{N} / \mathrm{m}^{2}$ per week (Deschampsia sites). Net mineralization expressed as percentage of total $\mathrm{N}$ amounted to approximately $4.0 \%$ for the Calluna, Erica, and Molinia locations and $6.0 \%$ for Deschampsia sites; nitrification expressed as percentage of total $\mathrm{N}$ mineralization was extremely variable among and within plant species (2-29\%) with the mean percentage for Deschampsia sites $(20 \%)$ significantly higher than that for Erica sites (7\%).

\section{Correlations and regressions}

Table 2 presents a correlation matrix for most of the soil properties listed in the appendix and Table 1, but all these parameters refer to the $0-10 \mathrm{~cm}$ depth (FH included). For $\mathrm{pH}$ the arithmetic average of the $0-5$ and $5-10 \mathrm{~cm}$ field-moist samples was used. The first column shows the correlation of the observed net nitrification in the laboratory with the other measured soil variables. Nitrification was significantly correlated with net mineralization $(\mathrm{P}<0.001)$, initial nitrate- $\mathrm{N}(\mathrm{P}<0.001)$, moisture $(\mathrm{P}<0.05)$, phosphate parameters $(\mathrm{P}<0.001-0.01)$, and exchangeable $\mathrm{Al}$ $(\mathrm{P}<0.01)$ and not with $\mathrm{pH}$, total $\mathrm{N}$ and $\mathrm{C} / \mathrm{N}$ ratio. 
A simple regression with $\mathrm{N}$-mineralization as independent explanatory variable predicted the nitrification with an adjusted $\mathrm{R}^{2}$ of $0.47(\mathrm{P}<0.001$; Table 3$)$. In order to find the best predictive equation for the observed net nitrification in undisturbed soil cores, an all possible subset regression analysis (Anon., 1987) was used. Regressions were run with the following variables: net mineralization, initial nitrate- $\mathrm{N}$, labile organic $\mathrm{P}, \mathrm{pH}$, moisture, $\mathrm{C} / \mathrm{N}$ ratio, and exchangeable Al. Moisture, $\mathrm{C} / \mathrm{N}$ ratio and exchangeable $\mathrm{Al}$ did not significantly contribute to the predictions and the best prediction was obtained with a multiple regression equation using the remaining four variables (adjusted $\mathrm{R}^{2}$ of 0.75 ; Table 3 ).

Table 2. Correlation matrix for some selected properties of heathland soils $(n=41)$.

Data refer to the upper $10 \mathrm{~cm}$ (FH included) and to either intact cores (properties 1 to 6) or pretreated material (properties 7 to 18). Where relevant, data expressed on volume (or areal) basis are used.

$\begin{array}{lllllllll}1 & 2 & 3 & 4 & 5 & 6 & 7 & 8\end{array}$

\begin{tabular}{|c|c|c|c|c|c|c|c|c|}
\hline 1. Net nitrification & - & & & & & & & \\
\hline 2. Net mineralization & 0.69 & - & & & & & & \\
\hline 3. Initial $\mathrm{NO}_{3}^{-}-\mathrm{N}$ & 0.65 & 0.50 & - & & & & & \\
\hline 4. Initial $\mathrm{NH}_{4}^{3+}-\mathrm{N}$ & 0.01 & -0.10 & -0.15 & - & & & & \\
\hline 5. $\mathrm{pH}-4$ & 0.14 & -0.09 & -0.19 & 0.37 & - & & & \\
\hline 6. Moisture & -0.35 & -0.11 & -0.22 & 0.10 & -0.42 & - & & \\
\hline 7. Organic $\mathrm{C}$ & -0.14 & 0.18 & 0.05 & 0.12 & -0.50 & 0.66 & - & \\
\hline 8. Total N & 0.11 & 0.37 & 0.18 & 0.18 & -0.38 & 0.41 & 0.84 & - \\
\hline 9. $\mathrm{C} / \mathrm{N}$ & -0.22 & -0.20 & -0.18 & 0.05 & -0.20 & -0.05 & 0.06 & -0.19 \\
\hline 10. Total P & 0.54 & 0.46 & 0.10 & 0.04 & 0.03 & -0.07 & 0.06 & 0.33 \\
\hline 11. Total organic $P$ & 0.58 & 0.50 & 0.18 & -0.02 & -0.02 & -0.04 & 0.13 & 0.40 \\
\hline 12. Olsen $P$ & 0.41 & 0.34 & 0.09 & 0.01 & 0.10 & -0.16 & -0.10 & 0.11 \\
\hline 13. Labile organic $P$ & 0.65 & 0.52 & 0.27 & 0.04 & 0.03 & -0.14 & 0.00 & 0.30 \\
\hline 14. Total $\mathrm{NaHCO}_{2}-\mathrm{P}$ & 0.59 & 0.48 & 0.21 & 0.03 & 0.06 & -0.15 & -0.04 & 0.24 \\
\hline 15. Exchangeable $\mathrm{k}$ & -0.03 & 0.13 & 0.08 & 0.04 & -0.27 & 0.19 & 0.57 & 0.69 \\
\hline 16. Exchangeable $\mathrm{Ca}$ & -0.05 & 0.24 & -0.12 & 0.28 & -0.08 & -0.05 & 0.36 & 0.48 \\
\hline 17. Exchangeable $\mathrm{Mg}$ & -0.10 & 0.21 & -0.17 & 0.35 & -0.10 & 0.10 & 0.46 & 0.55 \\
\hline 18. Exchangeable Al & 0.48 & 0.35 & 0.33 & 0.01 & -0.12 & 0.07 & 0.32 & 0.47 \\
\hline 9 & 10 & 11 & 12 & 13 & 14 & 15 & 16 & 17 \\
\hline
\end{tabular}

\begin{tabular}{|c|c|c|c|c|c|c|c|c|c|}
\hline 9. & - & & & & & & & & \\
\hline 10. & -0.31 & - & & & & & & & \\
\hline 11. & -0.33 & 0.95 & - & & & & & & \\
\hline 12. & -0.39 & 0.67 & 0.54 & - & & & & & \\
\hline 13. & -0.40 & 0.91 & 0.88 & 0.82 & - & & & & \\
\hline 14. & -0.41 & 0.86 & 0.79 & 0.92 & 0.98 & - & & & \\
\hline 15. & -0.17 & 0.31 & 0.31 & 0.24 & 0.27 & 0.27 & - & & \\
\hline 16. & 0.31 & 0.02 & -0.01 & 0.02 & -0.03 & -0.01 & 0.44 & - & \\
\hline 17. & 0.12 & 0.23 & 0.20 & 0.24 & 0.18 & 0.21 & 0.66 & 0.83 & - \\
\hline 18. & -0.15 & 0.50 & 0.59 & -0.05 & 0.36 & 0.22 & 0.16 & -0.09 & -0.10 \\
\hline
\end{tabular}

Values $>0.40$ significant at the $1 \%$ level; $>0.50$ significant at the $0.1 \%$ level 
Table 3. Regression coefficients and coefficients of determination $\left(R^{2}\right)$ for relationships between mean net nitrification and net $\mathrm{N}$ mineralization rates ( $\mathrm{mg} \mathrm{N} / \mathrm{m}^{2}$ per week) in undisturbed soil cores in the laboratory at $20{ }^{\circ} \mathrm{C}(\mathrm{n}=41)$, (a) without and (b) with some other selected variables. All properties refer to the $0-10 \mathrm{~cm}$ depth (FH layer included).

$\begin{array}{llll}\text { Independent variable } & \text { Coefficient } & \mathbf{P} & \mathbf{R}^{2} \text { adjusted* }\end{array}$

(a) Simple regression

Constant

Net mineralization rate

(b) Multiple regression

Constant

Net mineralization rate

Initial nitrate- $\mathrm{N}\left(\mathrm{mg} / \mathrm{m}^{2}\right)$

Labile organic $\mathrm{P}(\mathrm{mg} / 100 \mathrm{cc})$

$\mathrm{pH}\left(\mathrm{H}_{2} \mathrm{O}\right)$
$-64.781$

0.2532

$-216.74$

0.1083

0.2189

15.928

42.597
0.0199

0.0000
0.4660

0.0018

0.0070

0.0000

0.0004

0.0056

* all $\mathrm{R}^{2}$ values are significant at $0.1 \%$ level.

\section{DISCUSSION}

The present study clearly indicates that the occurrence of nitrate and nitrification is a widespread phenomenon in Dutch heathland soils, representing rather wide ranges among all four investigated dominant plant species. Although at 6 of the 41 sites (3 with Erica, 2 with Calluna, and 1 with Molinia) no nitrate was initially measured, all sites demonstrated a net production of nitrate after the incubation of intact soil cores for 100 days at $20^{\circ} \mathrm{C}$. Nitrate formation has been reported to occur in many acid forest soils (Robertson, 1982). To what extent autotrophic and/or heterotrophic nitrifier populations are involved in this process in these soils is still largely a matter of debate. In the heathland soils studied, autotrophic bacteria seem to be the main nitrifying micro-organisms (Chapter 4).

Rates of net nitrate production observed in sieved, humus samples (Chapter 4) agreed with those found in the present study for intact $0-10 \mathrm{~cm}$ cores (Fig. 2), which supports the idea that nitrification in heathland soils is mainly restricted to the $\mathrm{FH}$ layer. Similarly, maximum nitrification has been reported to occur in the litter layer of an acid forest soil (Clays-Josserand et al. 1988). Deviations from the 1:1 line in Fig. 2 may be largely explained by differences in (1) pretreatment i.e. sieved compared to undisturbed soil and (2) incubation period. 
Net nitrate production in cores appeared to be highly significantly and positively correlated with initial nitrate- $\mathrm{N}, \mathrm{N}$ mineralization, and labile organic $\mathrm{P}$. The correlation with initial nitrate is conceivable and the coupling between nitrification and $\mathrm{N}$ mineralization has previously been noted (Chapter 5; Kreitinger et al., 1985). This coupling between mineralization and nitrification may in part be associated with microsites with an ammonification-induced increase in $\mathrm{pH}$ (Overrein, 1967), rather than to an increased availability of ammonium (Robertson 1982a; Vitousek $e t$ al. 1982)

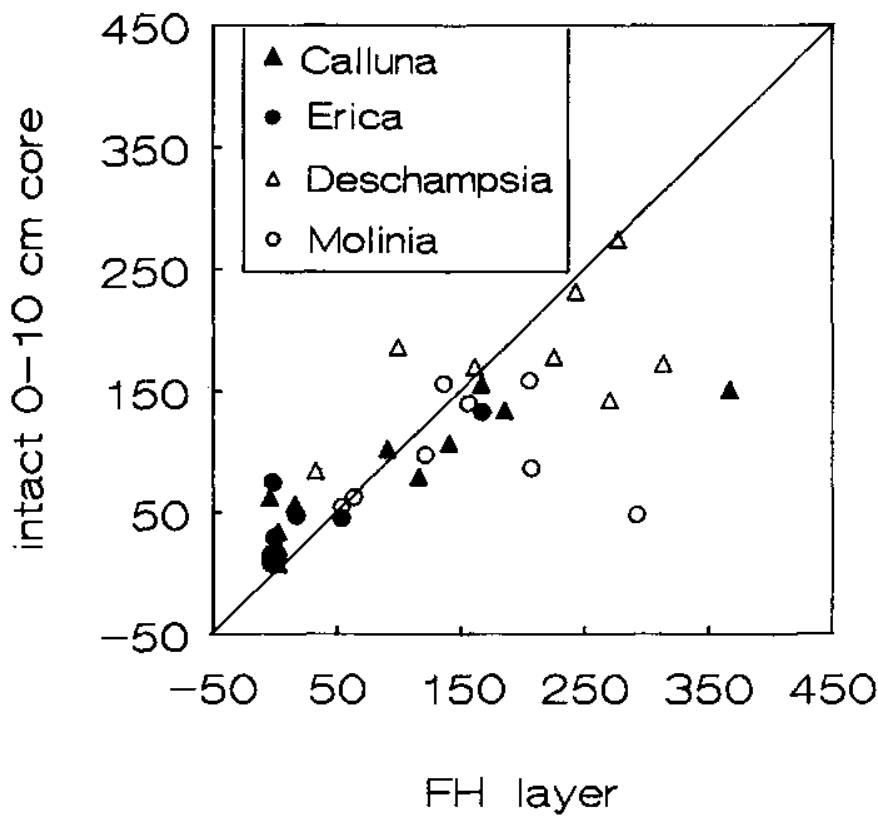

Fig. 2. Comparison between net nitrification rates ( $m g$ nitate-N/m² per week) in sieved, humus samples (FH layer) and in $0-10 \mathrm{~cm}$ soil cores (FH layer included) during incubation in the laboratory at $20^{\circ} \mathrm{C}$. Total period of incubation: 28 days (humus samples) or 100 days (intact cores).

The correlation with the labile organic P content suggests a causality, which is not so easily explained. Undescribed incubation experiments, with $P$ additions, have not provided any indication of nutrient limitation in a heathland soil that was low in both labile organic $\mathrm{P}$ and nitrification (Hoorneboeg). A possible explanation may be found in a coupling between mineralization/nitrification and the labile organic $P$ pool via microbial P. Srivasta and Singh (1988) have clearly indicated positive relationships between $P$ in the microbial biomass and bicarbonate extractable inorganic $\mathbf{P}$ (Olsen $\mathrm{P}$ ). Labile organic $\mathbf{P}$ is measured in the same extract and this parameter may even represent a better index for microbial P. A remarkable result of the present investigation was the better correlation of nitrification with labile organic $\mathbf{P}$ than with either Olsen $\mathbf{P}$ or total bicarbonate $\mathbf{P}$ (Table 2.). 


\section{CHAPTER III}

\section{TWO TYPES OF CHEMOLITHOTROPHIC NITRIFICATION IN ACID HEATHLAND HUMUS}

W. DE BOER, P.J.A. KLEIN GUNNEWIEK, S.R. TROELSTRA AND H.J. LAANBROEK

Published in: Plant and Soil 119 (1989) 229-235 


\begin{abstract}
The nature of nitrification in the organic horizons (FH) of two heathland soils was studied. Two types of chemolithotrophic nitrification but no heterotrophic nitrification were detected in the acid heathland humus. One type was predominant in slow nitrate producing humus. It was acid-sensitive but could be stimulated by urea at low $\mathrm{pH}$. The other type was acid-tolerant, it was not stimulated by urea. The latter type was predominant in fast nitrate producing humus. The occurrence of acid-tolerant chemolithotrophic nitrification provides indirect evidence for the existence of, previously unknown, acid-tolerant chemolithotrophic ammoniumoxidizing bacteria. Nitrification by these micro-organisms may be an important source of soil acidification in acid soils that are exposed to high levels of ammonium-deposition.
\end{abstract}

\title{
INTRODUCTION
}

In the Netherlands, soil acidification is a major environmental problem which is mainly due to high ammonium sulfate deposition in areas with intensive animal husbandry (Van Breemen $e t$ al., 1982). In these areas acidification of soils is caused by uptake of ammonium by the vegetation and by nitrification (Mulder, 1988). Even in the acid forest and heathland soils nitrification largely contributes to soil acidification (Van Breemen et al., 1987; Mulder, 1988). The question then arises which micro-organisms are responsible for nitrate production in the acid soils.

Generally, nitrification by chemolithotrophic bacteria is believed to occur in neutral environments only (Focht and Verstraete, 1977). Therefore, a possible contribution to nitrification in acid soils by chemo-organotrophic micro-organisms, especially fungi, has been suggested (Schimel et al., 1984; Killham, 1987). However, acid-tolerant nitrite-oxidizing Nitrobacter strains have been isolated recently from acid soils, indicating that at least chemolithotrophic nitrite-oxidation can occur in acid soils (Hankinson and Schmidt, 1988; Chapter 6). The existence of acid-tolerant ammonium-oxidizing bacteria has, so far, not been reported. The presence of acidsensitive ammonium-oxidizing chemolithotrophs in acid soils led Hankinson and Schmidt $(1984,1988)$ to propose that these organisms may be active in micro-sites that are less acid than the surrounding soil.

In this Chapter a study of the nature of nitrification in fast and slow nitrate producing acid heathland humus is described. Evidence is given for the existence of two types of chemolithotrophic ammonium-oxidation: a predominantly acid-sensitive, urea-stimulated process in slow nitrate producing humus and a predominantly acidtolerant process in fast nitrate producing humus. 


\section{MATERIAL AND METHODS}

\section{Site description and sampling}

All experiments used humus material from two heathland soils both located in the central part of the Netherlands: Hoorneboeg $\left(52^{\circ} 15^{\circ} \mathrm{N}, 5^{\circ} 10^{\circ} \mathrm{E}\right)$ and Kootwijk $\left(52^{\circ} 10^{\circ} \mathrm{N}, 5^{\circ} 50^{\circ} \mathrm{E}\right)$. The soils are podzolics (Typic Haplorthod) developed in glacial sandy sediments. The thickness of the organic horizon (FH) was $2.4 \pm 0.3$ $\mathrm{cm}$ and $3.6 \pm 0.4 \mathrm{~cm}$ for the Hoorneboeg soil and the Kootwijk soil, respectively. Preliminary experiments showed that humus of the Kootwijk location (KW) had a much higher nitrate production potential than that from the Hoorneboeg location (HB).

The vegetation of $\mathrm{HB}$ consisted of Calluna vulgaris and Deschampsia flexuosa. Earlier studies showing urea-stimulated chemolithotrophic nitrification at low $\mathbf{p H}$ were performed using HB soil from fertilized plots (Chapter 6). Humus samples used for this study were taken in an unfertilized part of the HB heathland dominated by old heather plants. The vegetation of $\mathrm{KW}$ consisted mainly of grasses with Molinia caerulea and Deschampsia flexuosa as the dominating species.

In March ' 88 approximately 40 cores $(\phi=2.4 \mathrm{~cm})$ were taken from the organic horizon (FH) and stored at $4{ }^{\circ} \mathrm{C}$. Subsequently, the cores were combined, mixed and sieved $(<4 \mathrm{~mm})$. Some properties of the mixed and sieved $\mathrm{HB}$ and $\mathrm{KW}$ humus are listed in Table 1. Experiments were started within 2 weeks of sampling.

Table 1. Some properties of humus (FH-horizon) from two Dutch heathlands:

Hoorneboeg (HB) and Kootwijk (KW) (March '88).

\begin{tabular}{lll}
\hline Characteristic & HB-humus & KW-humus \\
\hline pH(water) & 3.9 & 3.8 \\
Moisture content & \\
Maximum W.H.C. & $64.2 \%$ & $58.6 \%$ \\
Organic matter $^{\mathrm{b}}$ & $73.1 \%$ & $71.7 \%$ \\
Total nitrogen $^{\mathrm{b}}$ & $50.2 \%$ & $44.0 \%$ \\
Total phosphorus & $12.8 \mathrm{~g} / \mathrm{kg}$ & $0.45 \mathrm{~g} / \mathrm{kg}$ \\
Exchangeabie $\mathrm{NH}_{4}{ }^{+}-\mathrm{N}^{\mathrm{b}}$ & $0.61 \mathrm{~g} / \mathrm{kg}$ & $62 \mathrm{mg} / \mathrm{kg}$ \\
Exchangeable $\mathrm{NO}_{3}-\mathrm{N}^{\mathrm{b}}$ & $56 \mathrm{mg} / \mathrm{kg}$ & $34 \mathrm{mg} / \mathrm{kg}$ \\
\hline
\end{tabular}

\footnotetext{
a (wet weight - dry weight)/wet weight $\times 100$

b on basis of dry humus
}

\section{Nitrate production in field-moist humus}

Portions of field-moist humus, equivalent to 5 grams of dry weight humus, were transferred into serum flasks. The flasks were closed with a septum and a screw-cap. Subsequently, the flasks were incubated for three weeks at $20^{\circ} \mathrm{C}$ and the production of $1 M \mathrm{KCl}$-extractable $(50 \mathrm{ml}, 2 \mathrm{~h})$ ammonium and nitrate was determined. 
Production of mineral $\mathrm{N}$ was calculated by subtracting initial concentrations from those measured at the end of the incubation period. Parallel to this the effect of low concentrations of acetylene $(0.06 \% \mathrm{v} / \mathrm{v})$ on nitrate production was examined. Acetylene is an inhibitor of the enzyme ammonia mono-oxygenase (Hyman and Wood, 1985).

The vertical distribution of the nitrification activity in the soil was only examined for the KW location. Parallel to the incubation of humus (see above), sieved and field-moist soil $(0-5 \mathrm{~cm}$ and $5-10 \mathrm{~cm}$ below the $\mathrm{FH}$ horizon) was incubated. All experiments were done in duplicate.

\section{Effect of $\mathrm{pH}$ on nitrification}

The effect of the $\mathrm{pH}$ on nitrification was examined using humus suspensions. Portions of field-moist humus, equivalent to 5 grams of dry humus, were transferred into Erlenmeyer flasks. Demineralized water was added to give a ratio of 5 grams dry humus per 90 grams of water. Subsequently, $10 \mathrm{ml}$ of a $2 \mathrm{mmol} / \mathrm{l}$ solution of mineral salts $\left(\mathrm{KH}_{2} \mathrm{PO}_{4}, \mathrm{CaCl}_{2}, \mathrm{MgSO}_{4} \cdot 7 \mathrm{H}_{2} \mathrm{O}\right)$ was added. The $\mathrm{pH}$ was adjusted to $4.0,4.5,5.0,5.5$ and 6.0 using $1 \%$ ammonia. This adjustment led to different concentrations of ammonium at different $\mathrm{pH}$ values, ranging from $\sim 2 \mathrm{mM}$ at $\mathrm{pH} 4$ to $\sim 5 \mathrm{mM}$ at $\mathrm{pH}$ 6. Preliminary experiments had shown that this difference in ammonium concentrations did not affect the nitrification rate at the $\mathrm{pH}$ values studied.

The Erlenmeyer flasks were incubated at $20{ }^{\circ} \mathrm{C}$ on a rotary shaker operating at $100-150 \mathrm{rpm}$. The $\mathrm{pH}$ was adjusted daily using $1 \%$ ammonia. Weekly, the production of nitrate was determined. All experiments were done in triplicate.

\section{Effect of urea on nitrification}

From earlier work it was known that urea stimulated chemolithotrophic nitrification at low $\mathrm{pH}$ in suspensions of fertilized HB soil (Chapter 6). Therefore the effect of urea on nitrification in humus suspensions was also studied. Humus suspensions were prepared as described above but $1 \%$ suspensions instead of $5 \%$ suspensions were used. During 1 week the $\mathrm{pH}$ was adjusted to 5 using $5 \mathrm{mmol} / 1$ $\mathrm{Na}_{2} \mathrm{CO}_{3}$. Subsequently, $1 \mathrm{ml}$ of a solution containing $25 \mathrm{mmol} / /$ urea was added. To control suspensions $1 \mathrm{ml}$ of a solution containing $25 \mathrm{mmol} / 1\left(\mathrm{NH}_{4}\right)_{2} \mathrm{SO}_{4}$ was added. Incubation was as described above. The $\mathrm{pH}$ was adjusted daily using $5 \mathrm{mmol} / \mathrm{l}$ $\mathrm{Na}_{2} \mathrm{CO}_{3}$ or $5 \mathrm{mmol} / / \mathrm{H}_{2} \mathrm{SO}_{4}$. Nitrate was determined weekly.

\section{Effect of inhibitors on nitrification}

The nature of nitrification was studied using different inhibitors. With the exception of acetylene that was applied to field-moist humus $(0.06 \% \mathrm{v} / \mathrm{v})$, the effect of inhibitors was examined using humus suspensions. The inhibitors studied block the enzyme ammonia mono-oxygenase (nitrapyrin), the protein synthesis in fungi (cycloheximide) and the protein synthesis in bacteria (chloramphenicol, streptomycine), respectively. Humus suspensions were prepared as described above. 
Solutions of cycloheximide, chloramphenicol and streptomycine in water were added to give a final concentration of $100 \mathrm{mg} /$. Nitrapyrin (final concentration $20 \mathrm{mg} / \mathrm{l}$ ) was added to the flasks as a $10 \%$ solution in $96 \%$ ethanol before the suspensions were prepared. Ethanol was evaporated during an overnight incubation on a rotary shaker at $30{ }^{\circ} \mathrm{C}$. The $\mathrm{KW}$-humus suspensions were adjusted to $\mathrm{pH} 4$ and the $\mathrm{HB}$ humus suspensions to $\mathrm{pH} 5$. Suspensions were incubated as described above. The $\mathrm{pH}$ was adjusted daily using $1 \%$ ammonia. Nitrate production was determined weekly. All experiments, including controls without inhibitors, were done in triplicate.

\section{Mast probable number counts}

The increase in bacterial numbers during nitrification at low $\mathrm{pH}$ was studied using a dilution method. $5 \%$ suspensions of $\mathrm{KW}$-humus were prepared and incubated as decribed above. The $\mathrm{pH}$ was adjusted daily to 4 using $1 \%$ ammonia. Nitrate production was determined weekly. Every week dilutions were made according to the method that is described in Chapter 5, except that the dilution medium contained no sodium chloride. Preliminary experiments showed that the ammoniumoxidizing bacteria in $\mathrm{KW}$-humus could be counted when the $\mathrm{pH}$ of the dilution medium was 4.5 or 6.0 but not when it was 7.5. However, the counts at $\mathrm{pH} 4.5$ were not reliable because of the poor buffering of the medium at this $\mathrm{pH}$-value. Therefore, ammonium-oxidizing bacteria were counted at $\mathrm{pH}$ 6. Nitrite-oxidizing bacteria were counted at $\mathrm{pH} 6.5$. After 4 months of incubation at $20^{\circ} \mathrm{C}$ ammonium oxidation was checked using a pH-indicator (bromcresol purple) and nitrite oxidation was determined using Griess Ilosvay reagents. The MPN of nitrifying bacteria was estimated from statistical tables that were constructed using a computer program (Parnow, 1972).

\section{Analytical procedures}

The $\mathrm{pH}$ of the bumus was measured potentiometrically in $1: 2.5(\mathrm{w} / \mathrm{v})$ suspensions of humus in de mineralized water. The water content of the humus was determined as weight loss after overnight drying at $105{ }^{\circ} \mathrm{C}$. Organic matter was determined as weight loss of humus samples after ignition at $430^{\circ} \mathrm{C}$ for $24 \mathrm{~h}$. Total $\mathrm{C}$ in these humus samples can be estimated by multiplying the organic matter content by 0.6 . Total $\mathrm{N}$ and $\mathrm{P}$ were measured colorimetrically after digesting of the humus with a mixture of $\mathrm{H}_{2} \mathrm{SO}_{4}-\mathrm{Se}$ and salicylic acid (Houba et al., 1985). Exchangeable ammonium and nitrate were determined after extraction of the humus with $1 \mathrm{M} \mathrm{KCl}$ $(1: 5 \mathrm{w} / \mathrm{v})$ for 2 hours. Samples of humus suspensions were analyzed for nitrite and nitrate after centrifugation. Nitrite was never present in detectable amounts. Ammonium, nitrite and nitrate were measured colorimetrically using a Technicon Traacs autoanalyzer. Ammonium was measured colorimetrically as a reactionproduct of of sodium salicylate, sodium nitroprusside and sodium hypochlorite (Wall et al., 1975). Nitrite and nitrate, after reduction to nitrite in a copper-cadmium reductor cell, were measured colorimetrically as a reaction-product of sulfanilamide and N-1-naphtylethylenediamine (Keeney and Nelson, 1982). 


\section{RESULTS}

\section{Nitrate production in field-moist material}

The production of nitrate was much higher in KW-humus than in HB-humus (Table 2). The ratio of ammonium- $\mathrm{N}$ versus nitrate- $\mathrm{N}$ production was $1: 1$ for $\mathrm{KW}$ humus and 65:1 for HB-humus. This resulted in a drop of the $\mathrm{pH}$ of $\mathrm{KW}$-humus to -3.4 and a rise of the $\mathrm{pH}$ of $\mathrm{HB}$-humus to -4.2 .

The vertical distribution of the nitrification was examined for the $\mathrm{KW}$ heathland. The activity of the nitrifying organisms appeared to be mainly located in the FH horizon (Table 2). Core incubations showed that most of the nitrification at the HB heathland was also located in the FH horizon (not shown).

Table 2. Production of ammonium-N and nitrate-N ( $\mathrm{mg} \mathrm{N} / \mathrm{m}^{2}$ per week) in sieved field-moist humus and mineral soil.

\begin{tabular}{lccc}
\hline Soil sample & $\mathrm{pH}$ & $\begin{array}{l}\text { Ammonium-N } \\
\text { production }\end{array}$ & $\begin{array}{l}\text { Nitrate-N } \\
\text { production }\end{array}$ \\
\hline KW-humus & 3.8 & 181 & 178 \\
KW-mineral $(0-5 \mathrm{~cm})$ & 4.0 & 154 & 29 \\
KW-mineral $(5-10 \mathrm{~cm})$ & 4.3 & 56 & 0 \\
HB-humus & 3.9 & 169 & 3 \\
\hline
\end{tabular}

\section{Effect of pH and urea on nitrification}

Production of nitrate in HB-humus suspensions was markedly affected by the $\mathrm{pH}$ in contrast to those from KW-humus (Fig. 1 and 2). In HB-humus suspensions no nitrate-production was detected below an initial $\mathrm{pH}$ of 4.5 ; in KW-humus suspensions nitrate was produced at every $\mathrm{pH}$ value studied. When the $\mathrm{pH}$ of nitrifying suspensions was not adjusted nitrification stopped at pH 3.4 in HB-humus suspensions and at $\mathrm{pH} 2.8$ in $\mathrm{KW}$-humus suspensions (undescribed experiment).

The weekly production of nitrate increased with time. Therefore a doubling-time of the nitrate-production could be estimated with a modified equation for bacterial growth (Morill and Dawson, 1962):

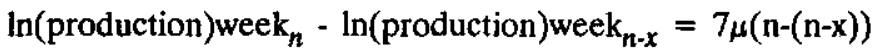

where $\mu$ is the increase in nitrate-production per day.

The doubling-time (Td) of the nitrate-production is then calculated:

$\mathrm{Td}=\ln 2 / \mu$ (days) 
The doubling-time of nitrate-production in $\mathrm{KW}$-humus suspensions was 6-8 days during the first weeks of incubation at all $\mathrm{pH}$ values studied (Fig. 2). At the higher $\mathrm{pH}$ values the doubling-time of nitrate-production in HB-humus suspensions was much shorter ( $\sim 2$ days $)$.

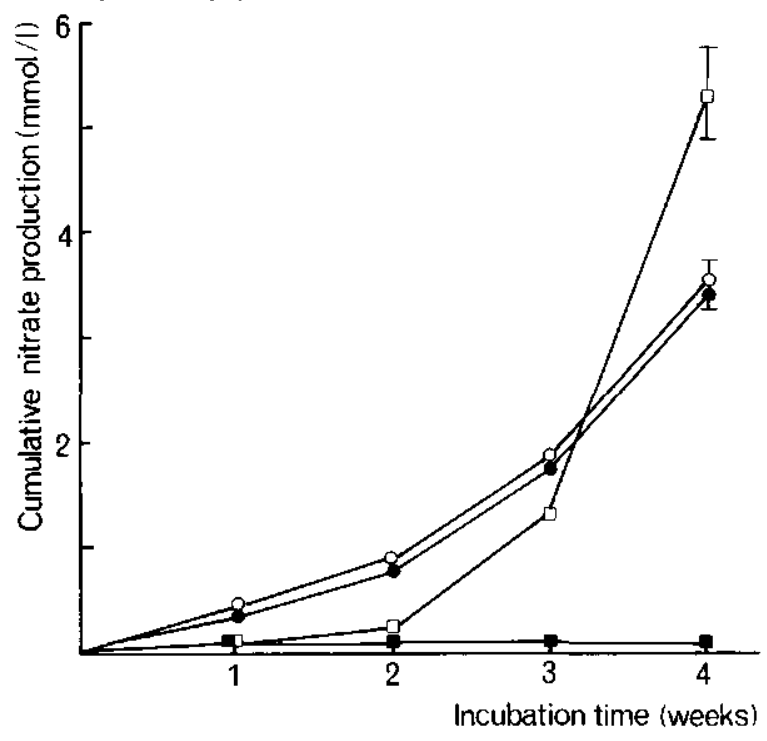

Fig. 1. Effect of pH on accumulation of nitrate in $5 \%$ heathland humus suspensions.

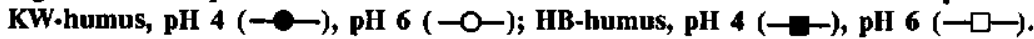
Bars represent standard deviation.

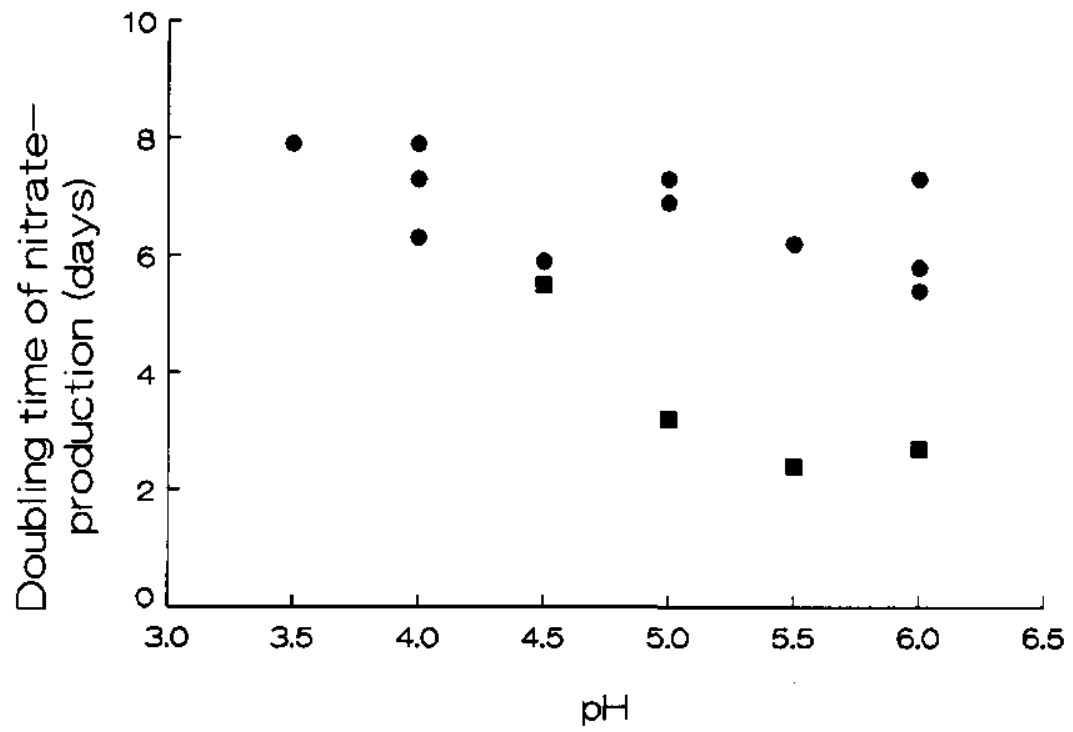

Fig. 2. Effect of $\mathrm{pH}$ on the doubling-time of nitrate-production in suspensions of KW-humus (O) and IIB-humus ( $(0)$. The doubling-time was calculated from the mean nitrate-production for the first 4 weeks of incubation. Similar symbols at the same pH value represent data of independent triplicate experiments. 
Hydrolysis of urea was followed by an increase of nitrification at $\mathrm{pH} 5$ in $\mathrm{HB}$ humus suspensions but not in $\mathrm{KW}$-humus suspensions (Fig. 3).

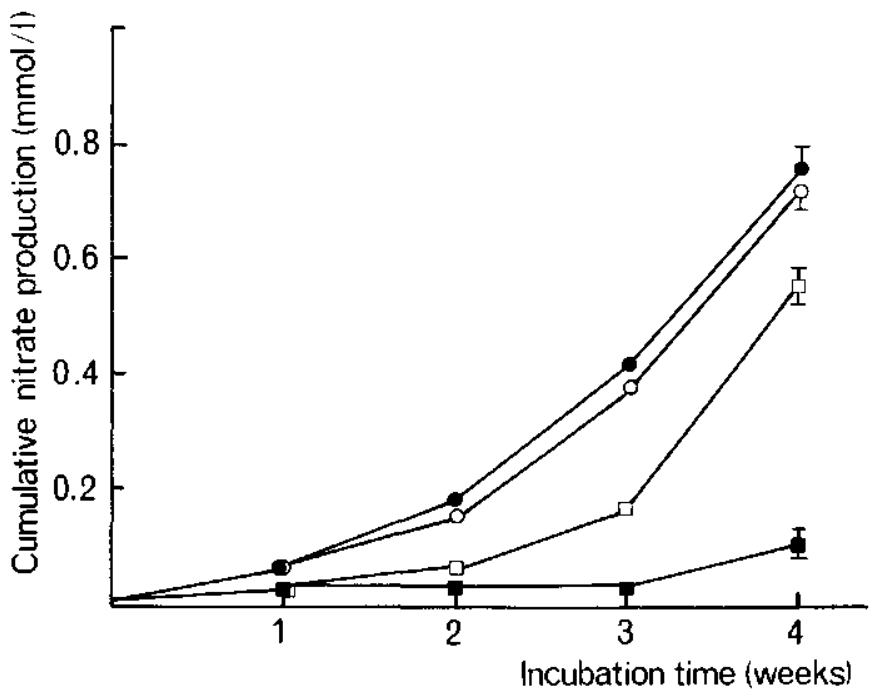

Fig. 3. Efrect of urea on accumulation of nitrate at pH 5 in $1 \%$ heathland humus suspensions.

KW-humus, $0.5 \mathrm{mM}\left(\mathrm{NH}_{4}\right)_{2} \mathrm{SO}_{4}(--), 0.5 \mathrm{mM}$ Urea ( $-\mathrm{O}-$ );

HB-humus, $0.5 \mathrm{mM}\left(\mathrm{NH}_{4}\right)_{2} \mathrm{SO}_{4}(-\longrightarrow), 0.5 \mathrm{mM}$ Urea (-口-). Bars represent standard deviation.

\section{Effect of inhibitors on nitrification}

The inhibitors of the enzyme ammonia mono-oxygenase, nitrapyrin and acetylene, completely blocked the production of nitrate in KW- and HB-humus (Table 3). Nitrification was not significantly inhibited by cycloheximide. Of the two inhibitors of bacterial protein synthesis only chloramphenicol had a significant inhibiting effect on nitrification.

Table 3. Effect of different inhibitors (\% inhibition) on production of nitrate in field-moist humus (acetylene) and in 5\% suspensions of heathland humus (other inhibitors).

Inhibitor

HB-humus

KW-humus

\begin{tabular}{lll} 
Nitrapyrin & 100 & 100 \\
Acetylene & 100 & 100 \\
Cycloheximide & n.s & n.s \\
Chloramphenicol & n.d & 35 \\
Streptomycin & n.d & n.s \\
\hline
\end{tabular}

n.s not significantly different $(\mathrm{P}>0.1)$ from the controls as determined by the small sample t-test. n.d not determined 


\section{Most probable number counts}

In KW-humus suspensions that were producing nitrate at $\mathrm{pH} 4$, the MPN of chemolithotrophic nitrite-oxidizing bacteria increased to $2.110^{7}$ cells per $\mathrm{ml}$ of suspension after 8 weeks of incubation (Fig. 4). However, the MPN of ammoniumoxidizing bacteria remained constant over the whole period of incubation although the weekly nitrate-production had increased almost 20 -fold (Fig. 4). At the end of the incubation period enumerations of the suspensions were also made in ammonium-medium of $\mathrm{pH} 7.5$ but these gave no positive results.

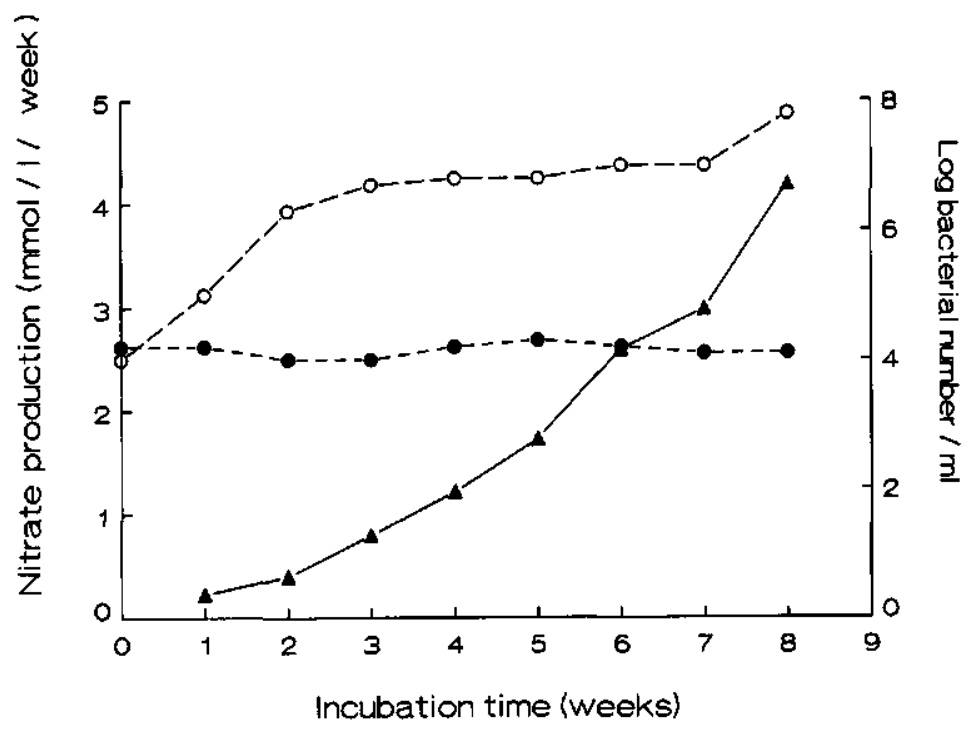

Fig. 4. Weekly nitrate-production ( $-1-$ ) and changes in most probable number counts of ammonium-oxidizing bacteria (--O--) and nitrite-oxidizing bacteria $\left(--\mathrm{O}^{-}\right)$in $5 \% \mathrm{KW}$-humus suspensions.

\section{DISCUSSION}

A comparison of the nature of nitrification in fast (KW) and slow (HB) nitrate producing heathland humus revealed two types: predominantly acid-sensitive nitrification in HB-humus and predominantly acid-tolerant nitrification in KWhumus. The inhibition of nitrification in KW- and HB-humus by nitrapyrin and acetylene indicates that the ammonium-oxidizing micro-organisms possess the enzyme ammonia mono-oxygenase. Therefore nitrification by fungi probably is of minor importance because with fungal nitrification other enzymes appear to be involved (Schimel et al., 1984; Killham, 1987). The minor importance of fungal nitrification is also indicated by the fact that cycloheximide, an inhibitor of 
eukaryotic enzyme synthesis, had little effect on nitrification in the HB- and KWhumus suspensions. Thus, it seems evident that the predominant nitrifying microorganisms in HB- and $\mathrm{KW}$-humus are bacteria. This is also supported by the fact that chloramphenicol, an inhibitor of bacterial enzyme synthesis, retarded the nitrate production in $\mathrm{KW}$-humus suspensions.

A combination of bacterial inhibition and inhibition of the enzyme ammonia mono-oxygenase is almost always interpreted as an indication of chemolithotrophic nitrification (Schimel et al., 1984; Killham, 1987; Chapter 5). However, this interpretation must be studied carefully as at least two other physiological groups of bacteria possess enzyme systems that are related to the ammonia mono-oxygenase system of chemolithotrophic ammonium-oxidizing bacteria: methanotrophic bacteria and bacteria that are capable of aerobic denitrification (Topp and Knowles, 1982; Robertson, 1988). Kreitinger et al. (1985) argued that nitrapyrin-inhibited nitrification in an acid forest soil is caused by methanotrophic-like bacteria.

The main difference between chemolithotrophic ammonium-oxidizing bacteria and other bacteria that possess ammonia mono-oxygenase or an enzyme with similar properties is the mode of energy-generation and carbon-assimilation: chemolithotrophic ammonium-oxidizing bacteria grow on ammonium and fix carbon dioxide while heterotrophic nitrifying bacteria grow on organic substrates and produce carbon dioxide. In $\mathrm{HB}$ - and $\mathrm{KW}$-humus suspensions the rate of nitrate production increased with time which implies that the nitrifying bacteria were growing. However the increasing nitrification rate was not accompanied by an increasing loss of carbon from the suspensions and after prolonged incubation nitrification proceeded without any measurable loss of carbon (data not shown). Therefore it is believed that bacterial heterotrophic nitrification cannot explain the observed exponential production of nitrate in humus suspensions. Consequently, the nitrification in $\mathrm{HB}$ - and $\mathrm{KW}$-humus is probably caused by chemolithotrophic nitrifying bacteria.

The predominant chemolithotrophic ammonium-oxidizing bacteria in the slow nitrate producing HB-humus appear to be acid-sensitive, since in HB-humus suspensions ammonium was oxidized at $\mathrm{pH} 6$ but not at $\mathrm{pH}$ 4. Furthermore MPN counts of HB-humus were positive at $\mathrm{pH} 7.5$ and $\mathrm{pH} 6.0$ but not at $\mathrm{pH} 4.5$ (data not shown). These observations agree with the finding that chemolithotrophic ammonium-oxidizing bacteria isolated from acid soils cannot oxidize ammonium in liquid mineral medium at low $\mathrm{pH}$ (Weber and Gainey 1962; Hankinson and Schmidt 1984; Martikainen and Nurmiaho-Lassila 1985).

The stimulation of nitrification by urea in HB-humus suspensions at $\mathrm{pH} 5$ may imply that the population of chemolithotrophic ammonium-oxidizing bacteria fully or partly consists of ureolytic bacteria. This is supported by the fact that in HB-humus bacteria were present that cross-reacted with fluorescent antibodies prepared against an ureolytic, ammonium-oxidizing chemolithotroph isolated from a fertilized part of the HB-location. It has been shown that this isolate is able to nitrify at a $\mathrm{pH}$ value as low as 4.5 with urea but not with ammonium as substrate (Chapter 7). Therefore, it is concluded that nitrification in slow nitrate producing HB-humus is probably an urea-stimulated, acid-sensitive chemolithotrophic process. 
In suspensions of $\mathrm{KW}$-humus the rate of nitrification was not much influenced by the $\mathrm{pH}$.

Based on the doubling-time of nitrate-production it seems evident that at least the predominant ammonium-oxidizing bacteria are slow-growing organisms at all $\mathrm{pH}$ values studied. Since ammonium was oxidized to nitrate in $\mathrm{KW}$-suspensions at low $\mathrm{pH}$ both the ammonium-oxidizing bacteria and the nitrite-oxidizing bacteria have to be acid-tolerant. Acid-tolerant chemolithotrophic nitrite-oxidizing bacteria have recently been isolated (Hankinson and Schmidt, 1988; Chapter 7), but this is the first time that evidence is presented for the existence of acid-tolerant chemolithotrophic ammonium-oxidizing bacteria. The acid-tolerant ammoniumoxidizing bacteria are apparently not adapted to be active at neutral $\mathrm{pH}$ values, as dilutions of $\mathrm{KW}$-humus in mineral media of $\mathrm{pH} 7.5$ did not reveal any ammonium oxidation whereas dilutions in media of $\mathrm{pH} 6.0$ and 4.5 did. This is an important observation because it demonstrates that MPN counts in media of neutral $\mathrm{pH}$ cannot be used as evidence for the absence of chemolithotrophic nitrifiers in acid soils!

Using the MPN method it was shown that numbers of nitrite-oxidizing bacteria did increase while nitrification proceeded in acid KW-humus suspensions. However, this increase in numbers was not observed for the ammonium-oxidizing bacteria. It is possible that in the case of these bacteria the incubation period (4 months) was too short to demonstrate greater numbers. However, this is not likely because the greatest numbers were already measured after 2 months. Another explanation for the failure of showing increasing numbers of ammonium-oxidizing bacteria may be that these bacteria are not easily desorbed from the humus-particles. This is supported by two observations: (1) After the KW-humus suspensions were allowed to settle nitrification activity was measured in the sediment but not in the supernatant. (2) The highest positive dilutions of counts of ammonium-oxidizing bacteria were also the highest dilutions in which some particles could be observed. These observations may also indicate that attachment is necessary for acid-tolerant ammonium-oxidizing bacteria to be active.

It is concluded that the nitrification in fast nitrate producing $\mathrm{KW}$-humus is probably an acid-tolerant chemolithotrophic process in which the first step (ammonium-oxidation) is caused by attached bacteria. It seems plausible that acidtolerant chemolithotrophic nitrification can be a major source of soil acidification in acid soils as the responsible organisms can proliferate at the $\mathrm{pH}$-values that occur in these soils. Attempts are being made to isolate the acid-tolerant chemolithotrophic bacteria. 


\title{
CHAPTER IV
}

\section{NITRIFICATION IN DUTCH HEATHLAND SOILS. II. CHARACTERISTICS OF NITRATE PRODUCTION}

\author{
W. DE BOER, P.J.A. KLEIN GUNNEWIEK AND S.R. TROELSTRA
}

Submitted for publication to Plant and Soil 


\begin{abstract}
Some characteristics of nitrification in 41 humus samples of Dutch heathlands were studied. Most of the acid humus samples (30) showed accumulation of nitrate during a 4-week incubation of field-moist material. In these samples net nitrate production was completely blocked by $0.06 \%$ acetylene indicating that nitrification was probably of a chemolithotrophic nature. From a comparison of the net production of nitrate in humus suspensions at $\mathrm{pH} 4$ and $\mathrm{pH} 6$ a differentiation into four patterns could be made:

I. No nitrate production at either $\mathrm{pH}$ value studied (12 samples)

II. Acid-sensitive nitrate production (3 samples)

III. Acid-tolerant, $\mathrm{pH}$-dependent nitrate production (10 samples)

IV. Acid-tolerant, $\mathrm{pH}$-independent nitrate production (16 samples)

The results show that acid-tolerant, chemolithotrophic nitrification is wide-spread in Dutch heathland soils. Absence of potential net nitrate production in humus samples is most likely caused by limitations in the supply of ammonium or oxygen.
\end{abstract}

\title{
INTRODUCTION
}

The annual acid load in Dutch heathland and forest soils located in areas with high values of ammonium deposition, is mainly due to nitrogen transformations, including nitrification (Mulder, 1988). In heathland soils the process of nitrification is mainly restricted to the organic horizons (Chapter 3 ). It was shown that at least two types of chemolithotrophic nitrification exist in the humus of two heathland soils that were studied whereas no indications were found for the activity of heterotrophic nitrifiers (Chapter 3). These two types differed mainly with respect to the pH-dependency of the process: an acid-sensitive type of nitrification predominated in slow nitrate producing humus whereas an acid-tolerant type predominated in fast nitrate-producing humus.

In Chapter 2, it was indicated that nitrate is produced in many of these acid soils. In this Chapter attention is focused on the distribution of different nitrification types in the heathland soils studied.

\section{MATERIAL AND METHODS}

Samples of the FH horizon were taken in early spring 1988 from 17 heathland locations described in Chapter 2. Per location all dominant vegetation-types, i.e dominance of Calluna vulgaris, Deschampsia flexuosa, Erica tetralix or Molinia caerulea, were sampled. Sampling was done by taking randomly at least 40 cores ( $\phi$ $=2.4 \mathrm{~cm}$ ). The cores were stored at $4{ }^{\circ} \mathrm{C}$. Most experiments were started within two weeks after sampling. Before the start of the experiments the cores were mixed and sieved $(<4 \mathrm{~mm})$. 


\section{Characterization of nitrification}

The nature of nitrification, autotrophic or heterotrophic, was examined by determing the effect of low concentrations of acetylene $(0.06 \%)$ on the production of nitrate in field-moist humus. At this concentration acetylene, is believed to be a specific inhibitor of autotrophic nitrification (Hynes and Knowles, 1982). Of every humus sample two field-moist portions, equivalent to 5 grams of dry humus each, were weighed and put into screw-cap bottles $(315 \mathrm{ml})$. Water-saturated samples were dried at $20^{\circ} \mathrm{C}$ to $65 \%$ of the water holding capacity. Acetylene $(0.2 \mathrm{ml})$ was added through the septum to one of the portions, whereas the other portion served as a control. The flasks were incubated during 4 weeks at $20^{\circ} \mathrm{C}$. At the start as well as at the end of the incubation period all humus samples were analysed for ammonium and nitrate. The net production of ammonium and nitrate was calculated by subtracting the initial concentrations of mineral $\mathbf{N}$ from the final concentrations.

The sensitivity of the nitrifying micro-organisms towards acidity was determined by comparing the production of nitrate in $5 \%$ suspensions that were maintained at $\mathrm{pH}$ 4 and $\mathrm{pH} 6$, respectively. The $\mathrm{pH}$ was controlled by the addition of $1 \%$ ammonia. The suspensions were incubated in Erlenmeyer flasks on a rotary shaker (100 rpm) at $20^{\circ} \mathrm{C}$. Net production of nitrate was determined over a 3-week incubation period.

To study the presence of urea-stimulated ammonium-oxidizing bacteria, production of nitrate in $1 \%$ humus suspensions was compared in the presence and absence of urea at $\mathrm{pH} 5$ (Chapter 6).

\section{Analytical procedures}

Humus was analysed for $\mathrm{pH}$, moisture content, total $\mathrm{N}$, total $\mathrm{C}$ and mineral $\mathrm{N}$. Analytical procedures were the same as described in Chapter 2.

\section{RESULTS}

\section{Properties of humus samples}

Results of the humus samples analyses are listed in Table 1 . for each vegetation type. All humus samples were acid (range of $\mathrm{pH}$ : $3.5-4.6$ ). Mean $\mathrm{C} / \mathrm{N}$ ratios of humus from Deschampsia-and Molinia-sites were significantly lower (small sample t-test, $\mathrm{P}<0.05$ ) than those of humus from sites dominated by dwarf-shrubs. Mineral $\mathrm{N}$ concentrations ranged from 10 to $270 \mathrm{ppm}$. Mean concentrations were not significantly different between the humus samples of the locations dominated by the different plant species. All samples contained more ammonium- $\mathbf{N}$ than nitrate- $\mathrm{N}$ but the ammonium- $\mathrm{N} /$ nitrate- $\mathrm{N}$ ratios of the samples differed greatly $(2-1600)$. The lowest values were observed in some of the samples from Molinia-sites, whereas the highest were found in samples from extremely wet locations (e.g. Kampshei). 
Table 1. Properties of humus samples from Dutch heathlands (April '88)

\begin{tabular}{|c|c|c|c|c|c|c|c|}
\hline location & $\begin{array}{l}\text { depth of } \\
\text { FH (cm) }\end{array}$ & $\mathrm{pH}$ & $\begin{array}{c}\text { moisture } \\
(\%)^{\mathrm{a}}\end{array}$ & $\begin{array}{c}\text { total } N \\
(\%)^{\mathrm{b}}\end{array}$ & $\mathbf{C} / \mathbf{N}$ & $\begin{array}{r}\mathrm{NH}_{4}{ }^{+}-\mathrm{N} \\
(\mathrm{ppm})^{\mathrm{b}}\end{array}$ & $\begin{array}{r}\mathrm{NO}_{3}{ }^{-}-\mathrm{N} \\
\left(\mathrm{ppm}^{-}\right)^{\mathrm{b}}\end{array}$ \\
\hline \multicolumn{8}{|c|}{ Calluna-locations } \\
\hline Assel & 2.8 & 3.8 & 67 & 1.45 & 21.9 & 46.4 & 1.9 \\
\hline Dwingeloo & 2.4 & 4.4 & 65 & 1.17 & 21.0 & 211.8 & 7.0 \\
\hline Ede & 2.8 & 3.9 & 60 & 1.14 & 23.9 & 97.8 & 6.7 \\
\hline Ginkel & 2.5 & 3.8 & 66 & 1.40 & 21.6 & 86.5 & 9.6 \\
\hline Hoorneboeg & 2.4 & 3.9 & 64 & 1.28 & 22.6 & 56.1 & 0.7 \\
\hline Kampina1 & 2.7 & 3.8 & 67 & 0.98 & 26.3 & 9.3 & 0.2 \\
\hline Kampina2 & 1.5 & 3.8 & 53 & 1.15 & 21.7 & 80.0 & 12.4 \\
\hline Loon/Drunen & 0.6 & 4.3 & 50 & 0.35 & 23.7 & 17.8 & 0.0 \\
\hline Molenveld & 3.3 & 3.8 & 65 & 1.23 & 23.5 & 10.0 & 0.4 \\
\hline Reemsterveld & 3.3 & 4.4 & 66 & 1.12 & 22.4 & 158.6 & 0.9 \\
\hline Terlet & 2.6 & 4.1 & 52 & 0.78 & 18.7 & 83.9 & 5.9 \\
\hline Wolfheze & 3.0 & 4.1 & 44 & 0.48 & n.d & 44.7 & 5.3 \\
\hline \multicolumn{8}{|l|}{ Erica-locations } \\
\hline Assel & 3.1 & 3.8 & $73 *$ & 1.26 & 25.2 & 40.2 & 5.7 \\
\hline Balloo & 4.4 & 4.0 & 65 & 1.20 & 20.8 & 76.1 & 0.1 \\
\hline Deelen & 3.9 & 3.7 & $84 *$ & 1.41 & 26.0 & 133.4 & 0.2 \\
\hline Dwingeloo & 2.5 & 4.3 & 70 & 0.98 & 25.1 & 264.4 & 2.2 \\
\hline Hoenderloo & 3.5 & 3.8 & 69 & 1.45 & 23.5 & 64.3 & 2.1 \\
\hline Kampina & 3.5 & 3.8 & 65 & 1.13 & 24.6 & 125.0 & 12.1 \\
\hline Kampshei & 3.4 & 3.9 & $80^{*}$ & 1.80 & 19.3 & 160.3 & 0.1 \\
\hline Kootwijk & 3.0 & 3.8 & 64 & 1.14 & 24.6 & 47.4 & 2.1 \\
\hline Molenveld & 3.4 & 3.8 & 69 & 1.25 & 23.4 & 14.4 & 1.7 \\
\hline Uddel & 3.6 & 3.7 & $80 *$ & 1.71 & 21.3 & 66.5 & 0.3 \\
\hline \multicolumn{8}{|c|}{ Deschampsia-locations } \\
\hline Ede & 4.7 & 4.0 & 59 & 1.20 & 17.4 & 144.1 & 20.4 \\
\hline Ginkel & 3.8 & 4.1 & 56 & 1.04 & 20.9 & 114.1 & 9.2 \\
\hline Hoorneboeg & 3.7 & 3.9 & 63 & 1.02 & 24.7 & 75.7 & 0.1 \\
\hline Kootwijk & 3.8 & 4.4 & 66 & 1.63 & 16.1 & 23.9 & 8.3 \\
\hline Molenveld & 3.2 & 3.8 & 58 & 1.20 & 18.8 & 92.5 & 2.3 \\
\hline Reemsterveld & 4.7 & 4.0 & 54 & 0.85 & 22.9 & 69.9 & 5.6 \\
\hline Terlet & 4.5 & 4.5 & 57 & 1.02 & 15.9 & 15.6 & 3.2 \\
\hline Wolfheze1 & 3.9 & 4.2 & 63 & 1.56 & 17.6 & 125.1 & 5.1 \\
\hline Wolfhere2 & 2.9 & 4.2 & 52 & 1.12 & 16.9 & 112.9 & 6.0 \\
\hline \multicolumn{8}{|c|}{ Molinia-locations } \\
\hline Assel & 3.8 & 3.5 & 64 & 1.30 & 22.1 & 48.4 & 22.7 \\
\hline Balloo & 4.2 & 3.9 & 68 & 1.16 & 18.6 & 81.4 & 10.0 \\
\hline Dwingeloo & 1.3 & 4.1 & 64 & 1.16 & 22.1 & 145.3 & 7.5 \\
\hline Ede & 2.6 & 3.6 & 50 & 1.00 & 20.7 & 37.6 & 23.5 \\
\hline Kampina & 3.2 & 3.7 & 58 & 0.91 & 21.1 & 53.6 & 29.0 \\
\hline Kampshei & 4.3 & 3.9 & $79 *$ & 1.44 & 21.8 & 109.2 & 0.1 \\
\hline Kootwijk & 3.6 & 3.6 & 59 & 1.22 & 20.8 & 61.9 & 34.1 \\
\hline Reemsterveld & 2.9 & 3.6 & 61 & 1.34 & 20.1 & 49.3 & 23.8 \\
\hline Terlet & 2.1 & 4.6 & 53 & 0.91 & 21.8 & 49.3 & 8.3 \\
\hline Uddel & 3.5 & 3.8 & $85 *$ & 1.98 & 17.3 & 142.6 & 0.5 \\
\hline
\end{tabular}

n.d. not determined

* water-saturated samples

a (wet weight - dry weight)/wet weight $\times 100$

b on basis of dry humus 
Data of net mineral $\mathrm{N}$ production in field-moist humus, in the absence of acetylene, are listed in Table 2 . Net mineral $\mathrm{N}$ production ranged from 0.3 to 77 ppm per week. The mean value of net $N$ mineralization in humus of Deschampsia-sites was significantly higher $(\mathrm{P}<0.1)$ than that of humus from other sites. Net mineral $\mathrm{N}$ production was not affected by the addition of acetylene (not shown).

Humus samples from 11 sites did not show net nitrate production with or without addition of acetylene. These samples originated from 1 Molinia-site, 4 Calluna-sites and 6 Erica-sites. In some of these samples (e.g. Dwingeloo-Calluna) nitrate concentrations decreased during the incubation period which may indicate that nitrate reduction occurred.In the other humus samples (30) net nitrate-N production ranged from 0.1 to $16 \mathrm{ppm}$ per week. Relative nitrification, i.e. the proportion of total mineral $\mathrm{N}$ that is produced as nitrate- $\mathrm{N}$, ranged from $0-86 \%$. Nitrate producing humus samples were not restricted to sites dominated by certain plant species.

Table 2. Some data on $\mathbf{N}$ mineralization and nitrate production in heathland humus samples

\begin{tabular}{|c|c|c|c|c|c|c|c|}
\hline \multirow[t]{2}{*}{ Locations } & \multicolumn{4}{|c|}{$\begin{array}{l}\text { Accumulation of mineral- } \mathrm{N} \text { and } \\
\text { nitrate- } \mathrm{N} \text { (mg } \mathrm{N} / \mathrm{kg} \text { humus/wk) }\end{array}$} & \multirow[b]{2}{*}{$\stackrel{\text { ratio }}{\mathrm{pH} 6 / \mathrm{pH} 4}$} & \multirow[b]{2}{*}{$\begin{array}{l}\text { urea } \\
\text { stimu- } \\
\text { lation }\end{array}$} & \multirow[b]{2}{*}{ pattern } \\
\hline & $\begin{array}{l}\text { mineral-N } \\
\text { in humus* }\end{array}$ & $\begin{array}{l}\mathrm{NO}_{3}^{-}-\mathrm{N} \\
\text { in humus* }\end{array}$ & $\begin{array}{l}\mathrm{NO}_{3}{ }^{-} \\
\text {suspe } \\
\text { pH4 }\end{array}$ & $\begin{array}{l}\mathrm{J} \text { in } \\
\text { ions } \\
\mathrm{pH} 6\end{array}$ & & & \\
\hline \multicolumn{8}{|c|}{ Calluna-locations } \\
\hline Assel & 20.3 & 7.4 & 70.0 & 76.0 & 1.1 & & IV \\
\hline Dwingeloo & 15.5 & -0.7 & 18.7 & 483.1 & 25.8 & + & III \\
\hline Ede & 19.3 & 8.2 & 59.7 & 99.9 & 1.7 & & III \\
\hline Ginkel & 42.5 & 13.7 & 154.9 & 119.9 & 0.8 & & IV \\
\hline Hoorneboeg & 18.1 & 0.3 & 0.0 & 119.8 & $\infty$ & + & II \\
\hline Kampina1 & 0.3 & 0.0 & 0.0 & 0.0 & - & & I \\
\hline Kampina2 & 27.5 & 8.3 & 107.3 & 144.7 & 1.3 & & IV \\
\hline Loon/Drunen & 3.2 & 0.0 & 0.0 & 0.0 & - & & I \\
\hline Molenveld & 0.8 & 0.0 & 0.0 & 0.0 & - & & I \\
\hline Reemsterveld & 14.6 & 0.6 & 18.7 & 193.7 & 10.4 & + & III \\
\hline Terlet & 24.0 & 8.0 & 26.1 & 24.2 & 0.9 & & IV \\
\hline Woltheze & 12.1 & 8.3 & 37.3 & 47.3 & 1.3 & & IV \\
\hline \multicolumn{8}{|l|}{ Erica-locations } \\
\hline Assel & 2.1 & -0.8 & 0.0 & 0.0 & - & & I \\
\hline Balloo & 17.9 & 0.0 & 0.0 & 0.0 & - & & I \\
\hline Deelen & 4.8 & 0.0 & 0.0 & 0.0 & - & & I \\
\hline Dwingeloo & 8.4 & 2.7 & 39.2 & 45.2 & 1.1 & & IV \\
\hline Hoenderloo & 26.1 & 1.1 & 10.3 & 20.5 & 2.0 & & III \\
\hline Kampina & 18.1 & 9.1 & 71.9 & 149.3 & 2.1 & + & III \\
\hline Kampshei & 13.2 & 0.0 & 0.0 & 0.0 & - & & I \\
\hline Kootwijk & 16.6 & -0.1 & 0.0 & 0.0 & - & & I \\
\hline Molenveld & 5.0 & -0.2 & 0.0 & 0.0 & - & & I \\
\hline Uddel & 10.0 & 0.1 & 0.0 & 0.0 & - & & I \\
\hline
\end{tabular}


Table 2. (continued)

\begin{tabular}{|c|c|c|c|c|c|c|c|}
\hline \multirow[t]{2}{*}{ Locations } & \multicolumn{4}{|c|}{$\begin{array}{l}\text { Accumulation of mineral- } \mathrm{N} \text { and } \\
\text { nitrate-N (mg N/kg humus/wk) }\end{array}$} & \multirow[b]{2}{*}{$\begin{array}{l}\text { ratio } \\
\mathrm{pH} 6 / \mathrm{pH} 4\end{array}$} & \multirow[b]{2}{*}{$\begin{array}{l}\text { urea } \\
\text { stimu- } \\
\text { lation }\end{array}$} & \multirow[b]{2}{*}{ pattern } \\
\hline & $\begin{array}{l}\text { mineral-N } \\
\text { in humus* }\end{array}$ & $\begin{array}{l}\mathrm{NO}_{3}^{-}-\mathrm{N} \\
\text { in humus* }\end{array}$ & $\begin{array}{l}\mathrm{NO}_{3}- \\
\text { suspen } \\
\text { pH4 }\end{array}$ & $\begin{array}{l}\mathrm{N} \text { in } \\
\text { ions } \\
\text { pH6 }\end{array}$ & & & \\
\hline \multicolumn{8}{|c|}{ Deschampsia-locations } \\
\hline Ede & 32.3 & 14.9 & 107.3 & 162.9 & 1.5 & & III \\
\hline Ginkel & 36.1 & 13.7 & 99.9 & 127.6 & 1.3 & & IV \\
\hline Hoorneboeg & 24.3 & 0.2 & 0.0 & 0.0 & - & & I \\
\hline Kootwijk & 46.8 & 7.7 & 42.0 & 152.1 & 3.6 & & III \\
\hline Molenveld & 27.3 & 1.5 & 0.0 & 35.8 & $\infty$ & n.d & II \\
\hline Reemsterveld & 19.0 & 7.6 & 45.7 & 77.0 & 1.7 & & III \\
\hline Terlet & 77.3 & 15.9 & 60.7 & 121.5 & 2.0 & + & III \\
\hline Wolfheze1 & 34.1 & 7.2 & 40.1 & 44.8 & 1.1 & & IV \\
\hline Wolfheze2 & 38.0 & 11.9 & 36.4 & 36.4 & 1.0 & & IV \\
\hline \multicolumn{8}{|c|}{ Molinia-locations } \\
\hline Assel & 14.4 & 12.4 & 224.9 & 224.5 & 1.0 & & IV \\
\hline Balloo & 21.9 & 11.1 & 82.1 & 153.1 & 1.9 & & III \\
\hline Dwingeloo & 24.2 & 5.3 & 55.1 & 64.4 & 1.2 & & IV \\
\hline Ede & 22.3 & 10.8 & 196.9 & 235.5 & 1.2 & & IV \\
\hline Kampina & 20.0 & 11.5 & 223.1 & 251.1 & 1.1 & & IV \\
\hline Kampshei & 9.9 & 0.0 & 0.0 & 0.0 & - & & I \\
\hline Kootwijk & 20.9 & 10.6 & 165.2 & 177.8 & 1.1 & & IV \\
\hline Reemsterveld & 21.2 & 11.3 & 99.9 & 137.6 & 1.4 & & IV \\
\hline Terlet & 72.4 & 7.8 & 27.1 & 102.9 & 3.8 & + & III \\
\hline Uddel & 4.9 & 0.1 & 0.0 & 12.1 & $\infty$ & n.d & II \\
\hline
\end{tabular}

- incubation of sieved, field-moist humus at $20{ }^{\circ} \mathrm{C}$

+ accumulation of nitrate at $\mathrm{pH} 5$ was at least 1.5 times higher in suspensions with urea-addition than in suspensions with ammonium-addition; n.d not determined.

In all humus samples nitrate production was completely blocked by $0.06 \%$ acetylene indicating that nitrification was probably of a chemolithotrophic nature (not shown).

Using data from all humus samples $(n=41)$ regression-analysis revealed that nitrate production was significantly $(\mathrm{P}<0.005)$ and positively correlated with $\mathrm{N}$ mineralization $(r=0.59)$ and significantly, but negatively with the (initial) moisture content $(r=-0.54)$ and the $C / N$ ratio $(r=-0.51)$. Regression of nitrate production against $\mathrm{pH}$ and initial mineral $\mathrm{N}$ content did not reveal significant correlations. 
From a comparison of the net nitrate production in suspensions of the humus samples at $\mathrm{pH} 4$ and at $\mathrm{pH} 6$ a differentiation into four patterns could be made:

I. No nitrate production at both $\mathrm{pH}$ values studied $(\mathrm{n}=12)$

II. Acid-sensitive nitrate production: nitrate production at $\mathrm{pH} 6$ but not at $\mathrm{pH} 4$ $(n=3)$

III. Acid-tolerant, $\mathrm{pH}$-dependent nitrate production: nitrate production at both $\mathrm{pH}$ 6 and $\mathrm{pH} 4$ with the production at $\mathrm{pH} 6$ being at least 1.5 times faster than at $\mathrm{pH} 4(\mathrm{n}=10)$

IV. Acid-tolerant, $\mathrm{pH}$-independent nitrate production: nitrate production at both $\mathrm{pH} 6$ and $\mathrm{pH} 4$ with the production at both $\mathrm{pH}$ values being almost equal $(\mathrm{n}=16)$

Most of the humus samples, that did not show accumulation of nitrate in suspensions at either $\mathrm{pH}$ value studied, originated from Erica-dominated sites. Acid-tolerant nitrification, that is nitrate production at $\mathrm{pH} 4$ (patterns III and IV) is wide-spread in Dutch heathland soils; it was not found to be restricted to humus of certain vegetation-types. The acid-sensitive type of nitrification (pattern II) was found to be uncommon.

All humus samples that accumulated nitrate during the incubation of field-moist material also did so in suspensions, with the exception of Dwingeloo-Calluna.

The effect of urea on nitrification in suspensions at $\mathrm{pH} 5$ was said to be stimulating when the accumulation of nitrate in 3 weeks was at least 1.5 times higher in suspensions with urea-addition than in those with ammonium-addition. All humus-samples that showed a stimulation of the nitrate production by urea were also found to produce more nitrate at $\mathrm{pH} 6$ than at $\mathrm{pH} 4$ (patterns II and III). However, there were also some humus-samples with $\mathrm{pH}$-dependent nitrate production (pattern III) that did not show urea-stimulated nitrate production.

\section{DISCUSSION}

In all humus samples acetylene completely blocked the nitrate production indicating that nitrification in heathland humus is probably due to the activities of chemolithotrophic bacteria (Chapter 3). Therefore, nitrate production by fungi does not seem to be of quantitative importance in these soils. Using the same acetylene-block technique combined with antibiotic-treatments, it was indicated that nitrate production in some forest soils is mainly caused by fungi (Adams, 1986b; Killham, 1986). At the moment, it is not obvious which factors determine whether 
nitrification in acid soils is mainly autotrophic or heterotrophic.

In this study acid-tolerant chemolithotrophic nitrifying bacteria were shown to be wide-spread in Dutch heathland soils. Although the isolation of acid-tolerant nitrite-oxidizing bacteria has been reported (Hankinson and Schmidt, 1988; Chapter 7), thusfar no acid-tolerant ammonium-oxidizing bacteria have been isolated. Therefore, there is only indirect evidence for the existence of acid-tolerant, chemolithotrophic ammonium-oxidizing bacteria and all information about their physiology has to be deduced from suspension experiments.

The $\mathrm{pH}$-dependency of nitrate production in humus suspensions varied greatly between the humus samples studied. One group of humus samples (pattern IV) produced nitrate at almost equal rates at both $\mathrm{pH} 4$ and $\mathrm{pH}$. Another group of humus samples (pattern III) produced considerably more nitrate at $\mathrm{pH} 6$ than at $\mathrm{pH}$ 4. This difference in response to a $\mathrm{pH}$-rise may be due to the presence of predominantly acid-tolerant ammonium-oxidizing strains with growth rates that are more (pattern III) or less (pattern IV) affected by an increase in $\mathrm{pH}$ from 4 to 6 . However, another possibility may be the presence of both acid-tolerant and acid-sensitive strains in humus samples that show pH-dependent (pattern III) nitrate production. In that latter case, it can be expected that nitrate production at $\mathrm{pH} 6$ is the result of a combined activity of acid-tolerant and acid-sensitive strains whereas at $\mathrm{pH} 4$ only the acid-tolerant strains are active. The presence of both acid-sensitive and acid-tolerant strains in one humus sample may be indicated by those humus samples in which nitrate production in suspensions was both $\mathrm{pH}$-dependent and stimulated by urea. Previously, it was shown that a stimulation of the nitrate production in suspensions may indicate the presence of acid-sensitive, ureolytic ammonium-oxidizing bacteria (Chapter 6). Urea-stimulated nitrate production was not detected in any of the humus samples with $\mathrm{pH}$-independent nitrate production (pattern IV) indicating that the acid-tolerant ammonium-oxidizing bacteria may not be ureolytic.

It should be noted that there were humus samples with nitrification characteristics that deviated from those discussed above. These are samples with a $\mathrm{pH}$-dependent, acid-tolerant nitrate production (pattern III) that is not stimulated by urea (e.g. Kootwijk-Deschampsia). This type of nitrification may be the result of combined activities of acid-tolerant - and non-ureolytic, acid-sensitive ammonium-oxidizing strains.

Nitrite was not detected in any of the suspension experiments indicating that under all conditions studied, nitrite-oxidation was not the limiting step with respect to nitrate production. Therefore, the suspension experiments do not give information about the effect of a rise in $\mathrm{pH}$ on the process of nitrite-oxidation. It is obvious that acid-tolerant nitrite-oxidizing bacteria must be present in humus samples showing nitrate production at $\mathrm{pH} 4$ but it is unknown whether acid-sensitive, nitrite-oxidizing bacteria do contribute to nitrate production at $\mathrm{pH} 6$. Hankinson and Schmidt (1988) showed that acid-tolerant - and acid-sensitive nitrite-oxidizing bacteria do coexist in an acid forest soil.

It seems that acid-sensitive nitrate production, as opposed to acid-tolerant nitrate production, requires special conditions (suitable $\mathrm{pH}$ or the presence of urea). Therefore, it can be expected that the former type will be quantitatively less 
important than the latter with respect to nitrate production in heathland humus. Indeed, it was observed that humus samples with little or no nitrate formation in suspensions at $\mathrm{pH} 4$ but with much nitrate formation at $\mathrm{pH} 6$ produced only little nitrate during incubation of field-moist material.

Nitrate production in heathland soils is correlated with some soil factors which may give information about the regulation of nitrification in these soils (Chapter 2). The first prerequisite for nitrification is that a population of nitrifying bacteria can develop. Therefore, the properties of humus in which nitrifying bacteria seem to be absent may give information on the factors that are required to allow nitrifying bacteria to grow. It is supposed that the absence of nitrate production in suspensions either at $\mathrm{pH} 4$ and at $\mathrm{pH} 6$ indicates that low numbers of nitrifying bacteria were present in the humus at the time of sampling. This was the case with 12 humus samples. These samples also showed no or little accumulation of nitrate during incubation of field-moist material.

One factor that may determine whether nitrifying bacteria can grow is the supply of ammonium. It is known that in a vegetation dominated by young dwarf-shrubs immobilization of nitrogen predominates with, subsequently, low amounts of available ammonium both for plants and micro-organisms (Berendse, 1988). Low numbers of nitrifying bacteria in the humus of the dwarf-shrub sites in Kampina-1, Loon/Drunen and Molenveld may be due to low amounts of available ammonium as both initial ammonium concentrations and $\mathrm{N}$-mineralization were low in these humus samples. It was observed that also in many forest soils ammonium availability appears to control nitrification (Robertson, 1982; Vitousek et al., 1982).

Not only ammonium but also oxygen is needed in nitrate production. Soils in wet heathlands have been reported to be anaerobic during part of the year (Lache, 1976). Therefore, it can be imagined that the oxygen supply in such locations may not be sufficient for nitrification. In this study this may have the case for the sites dominated by Erica or Molinia in Asselt, Deelen, Kampshei and Uddel. Hence, it is concluded that low numbers of nitrifying bacteria in 9 out of 12 humus samples may be due to lack of ammonium or oxygen.

The three remaining sites (Kootwijk-Erica, Balloo-Erica and HoorneboegDeschampsia) are very interesting because low numbers of nitrifying bacteria seem to be present in the humus although ammonium supply and moisture conditions are apparently suitable. The low numbers of nitrifying bacteria in both Erica-sites is surprising as these sites are surrounded by a Molinia-vegetation with a strongly nitrate-producing humus. The possibility was studied whether Erica-humus on these sites contained toxic compounds because allelochemical inhibition has been reported to be a factor controlling nitrification (Rice, 1984). Furthermore, it was observed that the activity of pure cultures of nitrite-oxidizing bacteria was retarded by extracts of Erica-leaves (Bertru and Goma Tchimbakala, 1985). It appeared that nitrate production in suspensions containing both nitrifying Molinia-humus (Kootwijk) and non-nitrifying Erica-humus (Kootwijk) was not different from nitrate production in suspensions containing only Molinia-humus (undescribed experiment). Thus allelochemical inhibition does not seem to be the cause of low numbers of nitrifying bacteria in the Erica-humus. Still, it can be imagined that even in these two sites without extreme moisture conditions, oxygen supply may not have been sufficient for 
the nitrifying bacteria to proliferate. The Erica-humus in these sites, especially in the Kootwijk-site, is very compact as opposed to the surrounding Molinia-humus. Oxygen supply in the Erica-humus of these sites may be limited by diffusion. Clays-Josserand et al. (1988) suggested that the occurrence of nitrification in different organic layers of forest soils is dependent on the diffusion capacity for oxygen.

Also the absence of nitrate production in Hoorneboeg-Deschampsia remains puzzling. All conditions for nitrification seem to be suitable. It may be possible that the apparently favourable conditions did not exist until recently and therefore nitrifying bacteria may not have had enough time to build up a population of sufficient size.

From this study it has become obvious that $\mathrm{pH}$ is not a factor that determines whether or not chemolithotrophic nitrifying bacteria can exist in heathland humus. Previously, it has been shown that acid-tolerant nitrifying bacteria were able to grow exponentially even at $\mathrm{pH}$ values as low as 3.5 (Chapter 3). In addition, the production of nitrate in suspensions at $\mathrm{pH} 4$ of humus samples with acid-tolerant nitrification (pattern III and IV, $\mathrm{n}=26$ ) is negatively correlated $(\mathrm{r}=-.726)$ with humus-pH indicating that at the time of sampling the highest numbers of acid-tolerant, ammonium-oxidizing bacteria were present in the most acid humus. This may imply that the activities of acid-tolerant ammonium-oxidizing bacteria have resulted in a drop of the humus-pH, although a low in situ $\mathrm{pH}$ might also be explained by other processes.

\section{Acknowledgements}

This study was financially supported by the Dutch Priority Programme on Acidification and The Netherlands Integrated Soil Research Programme. 


\section{CHAPTER V}

\section{ACID-SENSITIVE, CHEMOLITHOTROPHIC NITRIFICATION IN A FERTILIZED, ACID HEATHLAND SOIL. I. GENERAL CHARACTERISTICS}

W. DE BOER, H. DUYTS AND H.J. LAANBROEK

Published in: Soil Biology and Biochemistry 20 (1988) 845-850 


\begin{abstract}
The nature of nitrification in fertilized, acid heathland soils was studied. Chemolithotrophic ammonium- and nitrite-oxidizing bacteria were enumerated in non-fertilized and fertilized heathland soils. Ammonium-oxidizing bacteria were not detected in the non-fertilized soils, whereas nitrite-oxidizing bacteria were only found in the organic layer. Enrichment of acid heathland soils with NPK fertilizer increased the number of chemolithotrophic ammonium- and nitrite-oxidizing bacteria in the organic (FH) layer as well as in the upper part of the mineral (Ah) layer, although the $\mathrm{pH}$ of the soil hardly changed with fertilization. In soil suspensions of the upper mineral layer of fertilized heathland soils, nitrification was shown to be chemolithotrophic as it was completely inhibited by the addition of nitrapyrin under both neutral and acid conditions. Nitrate production was strongly dependent on the $\mathrm{pH}$ of the suspension indicating that the ammonium-oxidizing bacteria in this heathland soil were acid-sensitive. Stimulation of nitrification by addition of peptone appeared to be due to the increase in $\mathrm{pH}$ caused by ammonification of peptone. Under acid conditions, net nitrate production seemed to be coupled with net mineralization. The possible influence of vegetation on nitrification is discussed.
\end{abstract}

\title{
INTRODUCTION
}

In the Netherlands, during the last two decades the development of intensive animal husbandry has led to an increased atmospheric deposition of ammonia and ammonium. The deposition of nitrogen is most pronounced in the eastern and southeastern parts of the country, where many of the heathlands are located on acid sandy soils (Buysman et al., 1984). A deposition value of $50 \mathrm{~kg} \mathrm{~N}^{\text {ha }} \mathrm{y}^{-1}$ is not exceptional.

It has been shown that enrichment of the nutrient-poor heathland soil in this way may cause a change in the vegetation. Under these conditions, the original vegetation dominated by Calluna vulgaris or Erica tetralix, can change into a vegetation dominated by the grass species Deschampsia flexuosa and Molinia caerulea (Heil and Diemont, 1983).

The changes in the composition of the vegetation are supposed to be related to shifts in the nitrogen cycle e.g. increased mineralization and nitrification (Berendse, 1986; Chapter 2). Production of nitrate implies that nitrification takes place, despite the low $\mathrm{pH}$ of these soils.

Nitrification in acid soils is a poorly understood process because it is not known which micro-organisms are involved. Until recently, all known chemolithotrophic nitrifiers were sensitive to a low $\mathrm{pH}$ (Chapter 1). It has been assumed that heterotrophic micro-organisms are the most important nitrifiers in acid soils where no chemolithotrophic nitrifiers could be detected and where specific inhibitors of chemolithotrophic nitrification had little influence on the formation of nitrate (Adams, 1986ab; Lang and Jagnow, 1986; Stroo et al., 1986; Killham, 1986). However, there are acid soils in which nitrification seems to be chemolithotrophic 
(Weier and Gilliam, 1986; Killham, 1986).

In Chapter 4 a newly discovered nitrification type, i.e. acid-tolerant chemolithotrophic nitrification, was reported to occur in many Dutch heathland soils. In this Chapter the nature of nitrification in a fertilized acid heathland soil, in which acidtolerant nitrifiers are apparently not present, is described.

\section{MATERIAL AND METHODS}

\section{Experimental site and sampling procedure}

In 1981 the Department of Plant Ecology of the State University of Utrecht started a fertilization experiment on "de Hoorneboegse heide", a heathland location in the Centre of the Netherlands. The main objective of the experiment was to study effects of nutrient availability and management on the plant species composition of a dry heathland. In 1981, at the start of the experiment, the vegetation consisted of Calluna vulgaris (80\%) and Deschampsia flexuosa (20\%). Every spring over a period of 6 years $0,100,200,400$ and $800 \mathrm{~kg}$ NPK-fertilizer $\mathrm{ha}^{-1} \mathrm{y}^{-1}$, respectively, had been applied to adjacent plots $\left(20 \mathrm{~m}^{2}\right)$ of heathland. The fertilizer contained $14 \% \mathrm{NH}_{4} \mathrm{NO}_{3}-\mathrm{N}, 16 \% \mathrm{P}_{2} \mathrm{O}_{5}, 18 \% \mathrm{~K}_{2} \mathrm{O}$ and trace-elements. By 1986, the fertilized plots were all dominated by Deschampsia flexuosa.

In November 1986 soil samples were collected from the organic horizon (FH) and the upper $5 \mathrm{~cm}$ of the first mineral horizon (Ah). Soil samples consisted of a mixture of at least 40 cores taken randomly within one experimental plot. After sampling the soil was stored at $4{ }^{\circ} \mathrm{C}$. Before the start of the experiments the soil was sieved $(<4 \mathrm{~mm})$. Some soil properties of the plots are shown in Table 1.

Table 1. Soil properties of the experimental plots on the "Hoorneboegse Heide" in November 1986.

\begin{tabular}{llcrrrrr}
$\begin{array}{l}\text { NPK- } \\
\text { fertilizer } \\
\left(\mathrm{kg} \mathrm{ha}^{-1} \mathrm{y}^{-1}\right)\end{array}$ & Hor. & $\mathrm{pH}$ & $\begin{array}{r}\mathrm{OM} \\
(\%)\end{array}$ & $\begin{array}{c}\text { Total N } \\
(\%)\end{array}$ & $\begin{array}{r}\mathrm{NH}_{4}{ }^{+}-\mathrm{N} \\
(\mathrm{ppm})\end{array}$ & $\begin{array}{r}\mathrm{NO}_{3}{ }^{-}-\mathrm{N} \\
(\mathrm{ppm})\end{array}$ & $\begin{array}{r}\text { P-water } \\
(\mathrm{ppm})\end{array}$ \\
\hline 0 & $\mathrm{O}$ & 3.6 & 42.5 & 0.964 & 38.7 & 5.7 & 1.3 \\
0 & $\mathrm{~A}$ & 3.9 & 4.1 & 0.082 & 2.5 & 1.1 & 0.4 \\
100 & $\mathrm{O}$ & 3.7 & 43.8 & 1.074 & 84.1 & 10.0 & 11.7 \\
100 & $\mathrm{~A}$ & 3.9 & 4.2 & 0.092 & 8.8 & 1.3 & 0.9 \\
200 & $\mathrm{O}$ & 3.7 & 47.1 & 1.108 & 130.6 & 15.8 & 12.0 \\
200 & $\mathrm{~A}$ & 4.0 & 3.6 & 0.092 & 19.6 & 2.0 & 10.8 \\
400 & $\mathrm{O}$ & 3.7 & 54.2 & 1.280 & 123.4 & 24.1 & 15.0 \\
400 & $\mathrm{~A}$ & 4.0 & 3.8 & 0.085 & 15.5 & 3.2 & 8.3 \\
800 & $\mathrm{O}$ & 3.8 & 42.2 & 1.100 & 113.4 & 28.6 & 15.8 \\
800 & $\mathrm{~A}$ & 4.1 & 3.4 & 0.084 & 19.6 & 5.7 & 15.1 \\
& & & & & & & \\
\hline
\end{tabular}

OM Organic Matter * Percentages are calculated for oven-dry soils.

The percentages of sand, silt and clay in the "Hoorneboeg" soil were 94, 3 and $3 \%$, respectively. The $\mathrm{pH}$ of the soil was hardly changed by the addition of the fertilizer. 


\section{Enumeration of nitrifiers}

Nitrifying organisms were enumerated using a Most Probable Number (MPN) technique. The medium contained $\left(\mathrm{l}^{-1}\right): \mathrm{KH}_{2} \mathrm{PO}_{4}, 100 \mathrm{mg} ; \mathrm{NaCl}, 500 \mathrm{mg}$; $\mathrm{MgSO}_{4} .7 \mathrm{H}_{2} \mathrm{O}, 40 \mathrm{mg} ; \mathrm{CaCl}_{2}, 20 \mathrm{mg} ; \mathrm{FeSO}_{4} .7 \mathrm{H}_{2} \mathrm{O}, 2.46 \mathrm{mg} ; \mathrm{Na}_{2} \mathrm{EDTA}, 3.31 \mathrm{mg}$; $\mathrm{NaMoO}_{4} .2 \mathrm{H}_{2} \mathrm{O}, 0.1 \mathrm{mg} ; \mathrm{MnCl}_{2}, 0.2 \mathrm{mg} ; \mathrm{ZnSO}_{4} .7 \mathrm{H}_{2} \mathrm{O}, 0.1 \mathrm{mg} ; \mathrm{CuSO}_{4} .5 \mathrm{H}_{2} \mathrm{O}, 20 \mu \mathrm{g}$; $\mathrm{CoCl}_{2}, 2 \mu \mathrm{g} ;\left(\mathrm{NH}_{4}\right)_{2} \mathrm{SO}_{4}, 330 \mathrm{mg}$ or $\mathrm{NaNO}_{2}, 35 \mathrm{mg}$. The $\mathrm{pH}$ was adjusted with $\mathrm{NaOH}$. After autoclaving the $\mathrm{pH}$ was $7.0-7.5$ and $6.0-6.5$ for the ammonium- and the nitrite-medium respectively.

Samples of $10 \mathrm{~g}$ field-moist soil were transferred into Erlenmeyer flasks containing $50 \mathrm{ml}$ of the autoclaved MPN medium without ammonium or nitrite. The suspensions were shaken $\left(200 \mathrm{rev} \mathrm{min}^{-1}\right)$ for $24 \mathrm{~h}$ at $20^{\circ} \mathrm{C}$. Samples $(0.25 \mathrm{ml})$ taken from these suspensions were diluted tenfold in sterile microplates containing $2.25 \mathrm{ml}$ of the ammonium- or the nitrite-oxidizer medium per well. Per dilution, eight replicates were made. The microplates were packed in aluminum foil and held at $25^{\circ} \mathrm{C}$ for two months. Ammonium-oxidation was checked using a pH-indicator (bromothymolblue) and nitrite-oxidation was determined using Griess Ilosvay reagents. The MPN of nitrifiers was estimated from statistical tables that were constructed using a computer program (Parnow, 1972).

\section{Soil suspension experiments}

To study the effects of $\mathrm{pH}$ and nitrapyrin on nitrate production, Ah-soil of the most fertilized plot was used. Field-moist soil samples $(10 \mathrm{~g})$ were transferred into $250 \mathrm{ml}$ Erlenmeyer flasks containing $100 \mathrm{ml}$ of a medium composed of $\mathrm{KH}_{2} \mathrm{PO}_{4}$, $\mathrm{CaCl}_{2}$ and $\mathrm{MgSO}_{4} \cdot 7 \mathrm{H}_{2} \mathrm{O}\left(0.2 \mathrm{mmol}{ }^{-1}\right.$ each $) . A \mathrm{pH}$ range was made by adding different amounts of $1.0 \mathrm{~N} \mathrm{KOH}$ during 1 week. Differences in potassium concentrations were corrected with $0.5 \mathrm{M} \mathrm{K}_{2} \mathrm{SO}_{4}$.

After $\mathrm{pH}$ adjustment the suspensions were amended with $\left(\mathrm{NH}_{4}\right)_{2} \mathrm{SO}_{4}(0.5 \mathrm{mmo}$ $\left.\mathrm{1}^{-1}\right)$ with or without nitrapyrin $\left(20 \mathrm{mg} \mathrm{l}^{-1}\right)$. Nitrapyrin was dissolved in $96 \%$ ethanol; equal amounts of ethanol $(20 \mu \mathrm{l})$ were added to the controls. The suspensions were incubated at $20^{\circ} \mathrm{C}$ on a rotary shaker operating at $150 \mathrm{rev} \mathrm{min}^{-1}$. Samples were taken weekly for the analysis of $\mathrm{pH}$, ammonium and nitrate. The experiments were performed in duplicate.

The effect of amendment of organic nitrogen on nitrate production was studied by adding either $14 \mathrm{mg}$ peptone- $\mathrm{N} \mathrm{I}^{-9}$ or $14 \mathrm{mg} \mathrm{NH}_{4}-\mathrm{Cl}-\mathrm{N} \mathrm{l}^{-1}$ to soil suspensions. It was assumed that ammonification of all peptone- $\mathrm{N}$ would result in a $\mathrm{pH}$ increase equivalent to the addition of $1 \mathrm{mmol} \mathrm{NaOH} \mathrm{l^{-1 }}$. Hence, $1 \mathrm{mmol} \mathrm{NaOH} \mathrm{l}^{-1}$ was added to suspensions containing $\mathrm{NH}_{4} \mathrm{Cl}$ at the start of the experiment. Controls without $\mathrm{N}$ additions were also included. Experiments were performed in triplicate. Incubation and sampling were done as described above.

Contribution of eukaryotes (fungi) to nitrate production was studied in soil

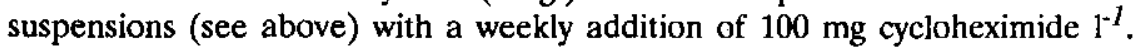




\section{Analytical procedures}

The $\mathrm{pH}$ of the humus was measured potentiometrically in $1: 2(\mathrm{w} / \mathrm{v})$ suspensions of soil in demineralized water. Organic matter in soil samples was determined by weight loss after ignition at $430{ }^{\circ} \mathrm{C}$ for $24 \mathrm{~h}$. Total $\mathrm{N}$ in soil was measured colorimetrically (indophenol-blue method) following digestion with a mixture of $\mathrm{H}_{2} \mathrm{SO}_{4}$-Se and salicylic acid (Novozamsky et al. 1984). Ammonium and nitrate were determined after extraction with $1 \mathrm{M} \mathrm{KCl}(1: 5 \mathrm{w} / \mathrm{v})$ for 2 hours. Water-extractable $(1: 40 \mathrm{w} / \mathrm{v})$ phosphate was measured colorimetrically using a molybdenum-blue method (Olsen and Sommers, 1982).

Samples of soil suspensions were analyzed for nitrate and nitrite after centrifugation and for ammonium after extraction with $1 M \mathrm{KCl}$ (2h) and centrifugation. Samples that were not immediately analyzed, were kept frozen until analysis. Concentrations of ammonium, nitrite and nitrate were measured using a Technicon autoanalyzer (Chapter 4).

\section{RESULTS}

\section{Numbers of nitrifying bacteria}
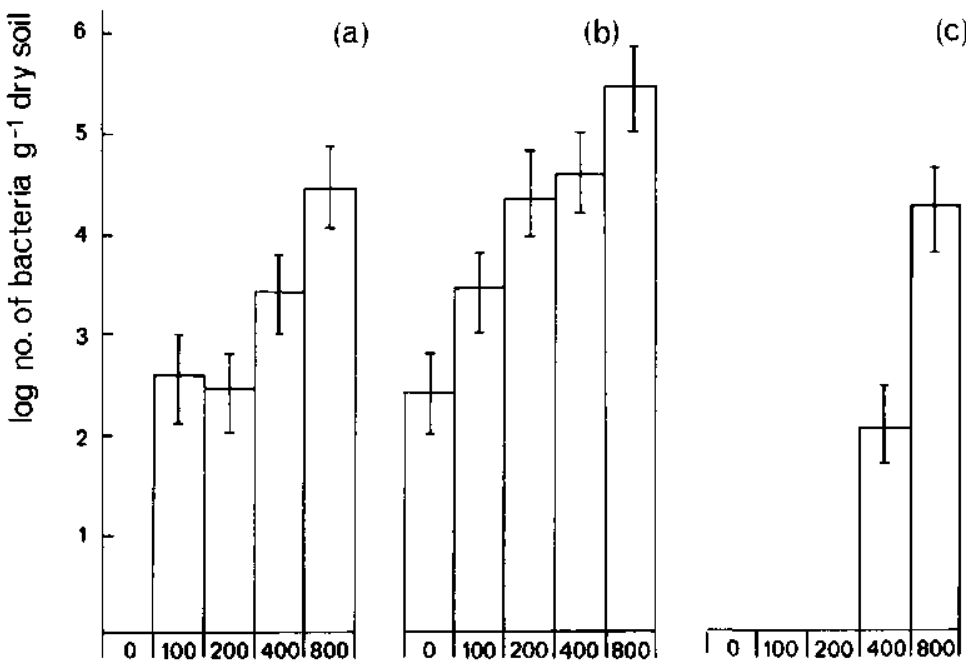

(c)

(d) NPK - Fertilizer Application $\mathrm{kg}^{-1} \mathrm{ha}^{-1}$ year ${ }^{-1}$

Fig.1. Numbers of chemolithotrophic nitrifying bacteria determined by the MPN method in heathland soils enriched annually with different amounts of NPK fertilizer. numbers of ammoniumoxidizing bacteria in the organic (FH) horizon (a) and in the upper mineral (Ah) horizon (c), numbers of nitrite-oxidizing bacteria in the organic (FH) horizon (b) and in the upper mineral (Ah) horizon (d). Vertical bars indicate $95 \%$ confidence limits. 
Despite the low $\mathrm{pH}$ of the heathland soil, fertilization resulted in an increase in the numbers of ammonium- and nitrite-oxidizing bacteria (Fig. 1). The increase corresponded with the application of NPK fertilizer. Except in the most fertilized plot, numbers of nitrifiers in the organic layer significantly exceeded those in the underlying mineral layer.

No ammonium-oxidizers were detected in the non-fertilized soil, whereas nitriteoxidizers were detected only in the organic horizon of the non-fertilized soil. Numbers of nitrite-oxidizing bacteria also exceeded the numbers of ammoniumoxidizing bacteria in each of the samples from the fertilized soils.

\section{Nitrate production in soil suspensions: effect of $\mathrm{pH}$ and nitrapyrin}

Nitrate production by ammonium-enriched suspensions of the Ah-layer from the most fertilized heathland plot is shown in Table 2 .

Table 2. Effects of $\mathrm{pH}$ and nitrapyrin on nitrate production in ammonium-enriched suspensions of the upper mineral (Ah) horizon of the most fertilized heathland plot. Supensions were incubated for 14 weeks at $20^{\circ} \mathrm{C}$. Data represent the mean of two replicates.

\begin{tabular}{|c|c|c|c|c|c|c|}
\hline $\begin{array}{c}\text { Initial } \\
\text { pH }\end{array}$ & $\begin{array}{c}\text { Nitrapyrin } \\
\text { addition } \\
\left(20 \mathrm{mg} \mathrm{l}^{-1}\right)\end{array}$ & $\begin{array}{c}\text { Initial } \\
\mathrm{NH}_{4}^{+}-\mathrm{N} \\
\left(\mathrm{mmol} \mathrm{l}^{-1}\right)\end{array}$ & $\begin{array}{c}\text { Initial } \\
\mathrm{NO}_{3}^{-}-\mathrm{N} \\
\left(\mathrm{mmol} \mathrm{l}^{-1}\right)\end{array}$ & $\begin{array}{c}\text { Final } \\
\mathrm{pH}\end{array}$ & $\begin{array}{c}\text { Final* } \\
\mathrm{NH}_{4}^{+}-\mathrm{N} \\
\left(\mathrm{mmol} 1^{-1}\right)\end{array}$ & $\begin{array}{c}\text { Final }^{*} \\
\mathrm{NO}_{3}^{*}-\mathrm{N} \\
\left(\mathrm{mmol} \mathrm{l}^{-1}\right)\end{array}$ \\
\hline 3.8 & - & 1.1 & 0.0 & 3.7 & 1.0 & 0.0 \\
\hline 3.8 & + & 1.1 & 0.0 & 3.9 & 1.1 & 0.0 \\
\hline 4.5 & - & 1.1 & 0.0 & 3.6 & 0.4 & 0.7 \\
\hline 4.5 & + & 1.1 & 0.0 & 4.2 & 1.0 & 0.0 \\
\hline 5.0 & - & 1.1 & 0.0 & 3.7 & 0.2 & 0.9 \\
\hline 5.0 & + & 1.1 & 0.0 & 4.7 & 1.1 & 0.0 \\
\hline 5.5 & - & 1.1 & 0.0 & 3.7 & 0.0 & 1.1 \\
\hline 5.5 & + & 1.1 & 0.0 & 5.1 & 1.1 & 0.0 \\
\hline 6.0 & - & 1.1 & 0.0 & 4.1 & 0.0 & 1.1 \\
\hline 6.0 & + & 1.1 & 0.0 & 5.6 & 1.1 & 0.0 \\
\hline 7.0 & - & 1.1 & 0.0 & 5.8 & 0.0 & 1.2 \\
\hline 7.0 & + & 1.1 & 0.0 & 7.4 & 1.3 & 0.2 \\
\hline
\end{tabular}

*Duplicates did not differ more than $0.05 \mathrm{mmol} \mathrm{l}^{-1}$

During the incubation period of 14 weeks, no nitrate accumulated in suspensions at the indigenous soil $\mathrm{pH}$ of 3.8. Nitrate accumulation started after 7 weeks in suspensions of $\mathrm{pH} 4.5$, after 4 weeks in suspensions of $\mathrm{pH} 5.0$ and within 1 week in suspensions of $\mathrm{pH} 5.5,6.0$ and 7.0. Nitrate production was always attended by a drop in $\mathrm{pH}$. Nitrapyrin completely inhibited the formation of nitrate under both neutral and acid conditions. This indicates that chemolithotrophic bacteria are wholly responsible for the formation of nitrate, even in the acid soil suspensions.

After the first week of incubation, ammonium $\left(0.3 \mathrm{mmol} \mathrm{r}^{-1}\right)$ was immobilized in all suspensions. This immobilization was followed by a net mineralization. In suspensions with nitrapyrin addition net ammonium production started after 7 weeks 
at $\mathrm{pH} 4.5$, after 4 weeks at $\mathrm{pH} 5.0$ and within a week at the other $\mathrm{pH}$ values. Thus the accumulation of nitrate in suspensions without nitrate addition seemed to coincide with the accumulation of ammonium in suspensions with nitrapyrin addition. This is surprising since at the start of the experiment enough exchangeable ammonium was available for the nitrification process. Therefore, it seems that there is a coupling between nitrification and mineralization which is not simply due to substrate limitation. In experiments without addition of ammonium sulphate production of nitrate started after 7 weeks at $\mathrm{pH} 4.5$, after 4 weeks at $\mathrm{pH} 5.0$ and within 2 weeks at the other $\mathrm{pH}$ values (except at $\mathrm{pH} 3.8$ where no nitrate production was observed). In these experiments all exchangeable ammonium was immobilized during the first week of incubation.

Nitrate production in suspensions: effect of peptone and cycloheximide

In comparison to the addition of ammonium and sodium hydroxide, addition of peptone did not stimulate the net nitrate production (Fig. 2).
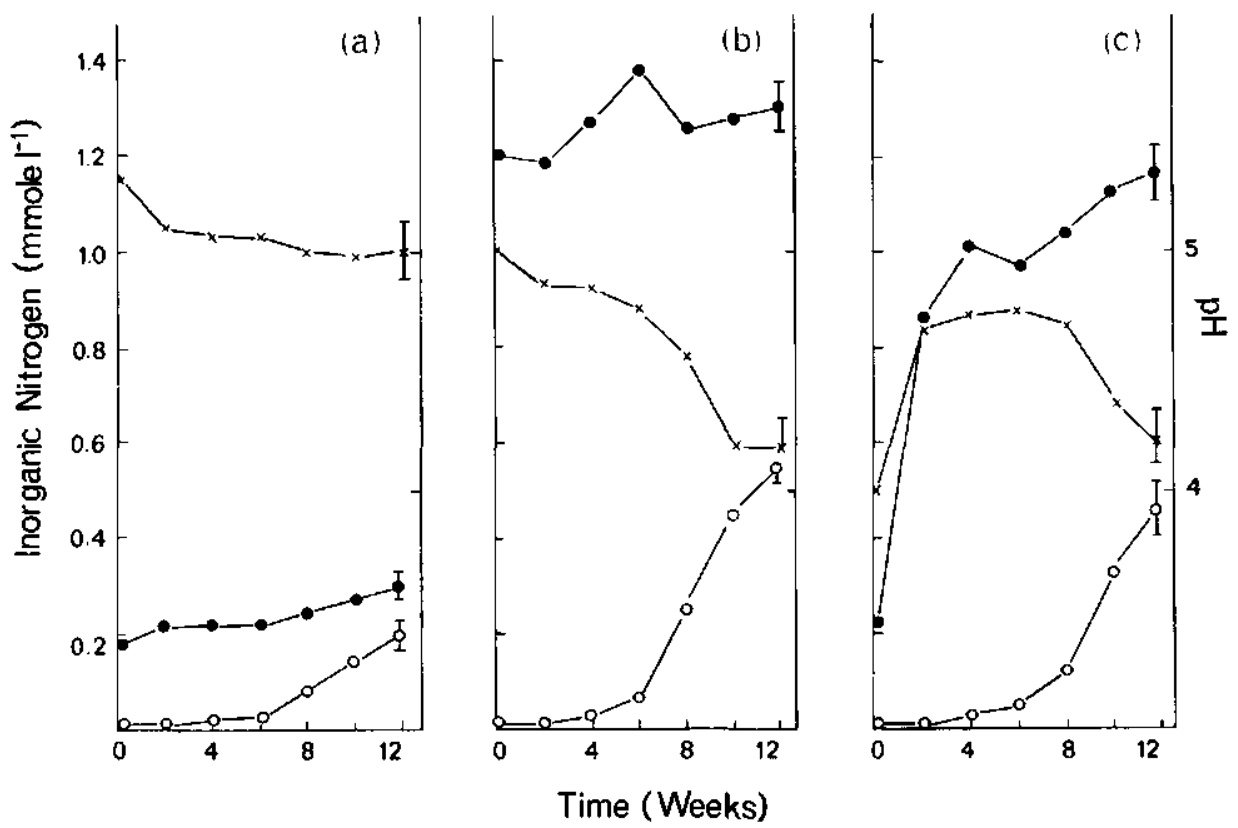

Fig. 2. Effect of peptone on nitrate accumulation in suspensions of soil from the upper mineral (Ah) horizon of the most fertilized heathland plot. (a) no nitrogen added, (b) ammonium chloride added ( $\left.1 \mathrm{mmol} \mathrm{I}^{-1}\right)$, (c) peptone-N added $\left(1 \mathrm{mmol} \mathrm{I}^{-1}\right)$. Suspensions without peptone addition have been corrected for increased $\mathrm{pH}$ due to ammonification of peptone, by addition of $\mathrm{NaOH}\left(1 \mathrm{mmol} \mathrm{\textrm {I } ^ { - 1 }}\right)$ at the start of the experiment. Incubations were done at $20^{\circ} \mathrm{C}$. Concentrations of $\mathrm{KCl}$-extractable mineral nitrogen $\left({ }_{-}\right)$, nitrate $\left(\mathrm{O}_{-} \mathrm{O}\right)$ and $\mathrm{pH}(\mathrm{x}-\mathrm{x})$ are presented. Data represent the mean of three replicates. Vertical bars indicate standard deviation. 
After 8-10 weeks of incubation, there was significantly less (Student's $t$-test, $P<0.1)$ nitrate accumulated in suspensions amended with peptone than in those amended with ammonium and sodium hydroxide. This may be attributed to a direct or indirect repression of nitrifiers by peptone, as we have found that weekly additions of peptone-N (4 $\left.\mathrm{mg} \mathrm{l}^{-1}\right)$ completely inhibited net nitrate production (undescribed experiment). In peptone-amended suspensions net nitrate production was completely inhibited by addition of nitrapyrin. Therefore, there is no evidence that heterotrophic nitrifiers are involved in the production of nitrate in the presence of peptone.

The production of nitrate seemed to be attended by a net $\mathrm{N}$ mineralization (Fig. 2). This agrees well with the observations, described in the previous section, namely that nitrification and net mineralization almost started simultaneously in acid soil suspensions.

Under both neutral and acid conditions, the net production of nitrate in soil suspensions amended with ammonium $\left(1 \mathrm{mmol} \mathrm{l}^{-1}\right)$ was not repressed by weekly additions of cycloheximide $\left(100 \mathrm{mg} \mathrm{l}^{-1}\right)$ (not shown). This indicates that heterotrophic nitrification by fungi is of minor importance in these suspensions.

\section{DISCUSSION}

Enrichment of the heathland plots with NPK fertilizer has resulted in an increase in the most probable numbers of chemolithotrophic nitrifiers, although the $\mathrm{pH}$ of the soil was still low. This is remarkable, as a similar increase in the most probable numbers of nitrifying bacteria has not been observed in acid forest soils fertilized with NPK, unless the $\mathrm{pH}$ of the soil had increased by additions of urea or calcareous compounds (Mai and Fiedler, 1983; Martikainen, 1985).

All chemolithotrophic ammonium-oxidizing bacteria isolated from acid soils did not grow in liquid media with a $\mathrm{pH}$ of less than 6.0 (Hankinson and Schmidt 1984; Martikainen and Nurmiaho-Lassila, 1985). Thus Hankinson and Schmidt (1984) assumed that the activity of ammonium-oxidizing bacteria is restricted to circumneutral micro-sites.

It seems that the ammonium-oxidizing bacteria we have enumerated using the MPN method were also not adapted to growth at low $\mathrm{pH}$ in liquid media, since enumerations using low $\mathrm{pH}$ (4.5) media always yielded very low numbers. The question therefore arises whether the NPK fertilization has had an indirect effect on the acid-sensitive nitrifiers by increasing, perhaps only temporarily, the number of circumneutral micro-sites. Such an effect might have been brought about by a different availability of the nitrate component and the ammonium component of the fertilizer to plants. This different availability might have been the result of a specific absorption of ammonium by the soil-organic complex. A predominant nitrate uptake by plants would make the rhizosphere more alkaline (Nye, 1981).

However, even at low $\mathrm{pH}$ nitrification seems to be completely chemolithotrophic in suspensions of heathland soil as net nitrate production was completely inhibited by nitrapyrin but not by cycloheximide. Since acid-tolerant, ammonium-oxidizing 
bacteria were apparently not present in these suspensions (no nitrate production at $\mathrm{pH} \mathrm{3.8)}$ it is assumed that acid-sensitive ammonium-oxidizing bacteria are somehow able to be active at rather low $\mathrm{pH}$ values.

Nitrate accumulation in acid soil suspensions seemed to be coupled with a net $\mathrm{N}$ mineralization although ammonium itself was not limited. It has been shown in ammonium-enriched suspensions of acid forest soils that $\mathrm{N}$ mineralization and nitrate production were significantly correlated (Kreitinger et al., 1985). However, this could be interpreted as a result of heterotrophic nitrification since, in contrast to our observations, nitrate production was only partly inhibited by nitrapyrin.

It is proposed that a coupling of acid-sensitive, chemolithotrophic nitrification and net $\mathrm{N}$ mineralization in this acid heathland soil implies that ammonifying microorganisms and ammonium-oxidizing bacteria are closely associated. This association is probably achieved by liberation of ammonia which induces a $\mathrm{pH}$ favourable for acid-sensitive, ammonium-oxidizing bacteria close to the ammonifying organisms.

The proposed coupling between nitrification and net $\mathrm{N}$ mineralization could also possibly explain why numbers of acid-sensitive, ammonium-oxidizing bacteria have increased by the NPK fertilization. It was shown that the NPK fertilization has resulted in an increase in accumulation of litter with a relatively high nitrogen content (Schildwacht and de Smidt, 1984). As a consequence it can be expected that $\mathrm{N}$ mineralization rates are higher in the most fertilized plots and, in turn, there may be more suitable conditions for acid-sensitive ammonium-oxidizing bacteria to proliferate.

The nature of nitrate production in acid soils has been the subject of many studies. The interpretation of experiments using selective inhibitors, as was done in this study, has always a certain risk because it is impossible to be sure that selectiveness of the inhibitors is complete (see Chapters 1 and 3 for a more extensive discussion). Organic $\mathrm{N}$-compounds have also been used to study the nature of nitrification in acid soils (Ishaque and Cornfield, 1976; Van de Dijk and Troelstra, 1980; Adams, 1986a). Stimulation of nitrification by addition of these compounds has been interpreted as a result of the activity of heterotrophic nitrifiers. From this study it has become clear that without additional experiments such an interpretation can be questioned. 


\section{CHAPTER VI}

\section{ACID-SENSITIVE, CHEMOLITHOTROPHIC NITRIFICATION IN A FERTILIZED, ACID HEATHLAND SOIL. II. EFFECT OF ORGANIC N-COMPOUNDS}

W. DE BOER, H. DUYTS AND H.J. LAANBROEK

Published in: Soil Biology and Biochemistry 21 (1989) 349-354 


\begin{abstract}
The effect of various organic-N compounds on nitrate production in suspensions of a fertilized heathland soil was studied. Urea increased nitrate production the most. Nitrification in these suspensions was stimulated specifically by urea and not by an increase of the $\mathrm{pH}$ due to urea hydrolysis, as the addition of equivalent amounts of ammonium carbonate or ammonium hydroxide resulted in a similar increase in the $\mathrm{pH}$ but had only limited effect on the production of nitrate. Numbers of chemolithotrophic nitrifiers increased significantly in urea-enriched suspensions although these suspensions remained acidic $(\mathrm{pH}<5)$. Nitrification was completely inhibited by nitrapyrin. An ammonium-oxidizing and a nitrite-oxidizing bacterium were isolated from the fertilized heathland soil. The ammonium-oxidizer was able to hydrolyse urea at low $\mathrm{pH}$. The ecological implication of the presence of urease-positive chemolithotrophic nitrifiers in acid soils is discussed.
\end{abstract}

\title{
INTRODUCTION
}

Formation of nitrate in acid soils has often been reported (Weber and Gainey, 1962; Robertson, 1982; Klein et al., 1983). Little is known about the process of acid nitrification because it is not clear which micro-organisms are involved. In the different soils that have been investigated, either heterotrophic or chemolithoautotrophic micro-organisms are thought to be responsible for the observed nitrification (Adams, 1986ab; Weier and Gilliam, 1986; Killham, 1986). Recently, heterotrophs were isolated which can nitrify in liquid media at low $\mathrm{pH}$ (Lang and Jagnow, 1986; Stroo et al., 1986). On the other hand, with the exception of an acidtolerant nitrite-oxidizing Nitrobacter strain described by Hankinson and Schmidt (1988), all chemolithotrophic nitrifiers that have been isolated from acid soils were not able to oxidize nitrogen at $\mathrm{pH}<5.5$ in a liquid medium (Hankinson and Schmidt, 1984; Martikainen and Nurmiaho-Lassila, 1984).

Acid-sensitive chemolithotrophic nitrifiers may be partly responsible for nitrate formation in acid soils as fertilization of such soils with nitrogenous compounds often results in an increase of these bacteria (Mai and Fiedler, 1983; Martikainen, 1985). In most cases this increase is observed only when soil $\mathrm{pH}$ is raised by fertilization e.g. by the application of urea or calcareous compounds. This has led to the assumption that acid-sensitive chemolithotrophic nitrifiers may be active in microsites with a relatively high $\mathrm{pH}$ (Overrein, 1967; Hankinson and Schmidt, 1984).

Using suspensions of a fertilized heathland soil it was found that acid-sensitive, chemolithotrophic nitrification can occur at low pH (Chapter 5). The onset of nitrification in these suspensions was associated with the start of net ammonification, despite the fact that ammonium was available from the start of the experiments. Therefore, it was proposed that in this heathland soil acid-sensitive ammoniumoxidation is activated by or coupled with ammonification.

Experiments presented in this Chapter deal with the effects of organic $\mathrm{N}$-compounds, especially urea, on nitrification in suspensions of this acid heathland soil and pure cultures of nitrifiers. 


\section{MATERIALS AND METHODS}

\section{Soil suspension experiments}

Soil was collected from the upper mineral horizon (Ah) of a fertilized plot $(800 \mathrm{~kg}$ fertilizer ha ${ }^{-1} \mathrm{yr}^{-1}$ composed of $\mathrm{NH}_{4} \mathrm{NO}_{3}-\mathrm{N}(14 \%), \mathrm{P}_{2} \mathrm{O}_{5}(16 \%), \mathrm{K}_{2} \mathrm{O}(18 \%)$ ) on "de Hoorneboegse Heide", a heathland location in the central part of the Netherlands. Data on fertilization and soil analysis have been presented in the previous Chapter. After sampling the soil was sieved $(<4 \mathrm{~mm})$ and stored at $4{ }^{\circ} \mathrm{C}$ until the experiments began.

In one series of experiments ammonium and nitrate production induced by the addition of different organic- $N$ sources was studied. Portions of 10 grams of moist soil were transferred into $250 \mathrm{ml}$ Erlenmeyer flasks containing $100 \mathrm{ml}$ of a solution of $\mathrm{KH}_{2} \mathrm{PO}_{4}, \mathrm{CaCl}_{2}$ and $\mathrm{MgSO}_{4} \cdot 7 \mathrm{H}_{2} \mathrm{O}(0.2 \mathrm{mmol} \mathrm{l}-1$ each). The suspensions were shaken (150 rev. min $^{-1}$ ) for a week at $20^{\circ} \mathrm{C}$. Organic-N compounds (urea, adenine, peptone, oxamide, chitin, respectively) were then added in amounts equivalent to 14 mg $\mathrm{N}^{-1}$ of suspension and incubation was continued. To study a possible inhibition of nitrification by either one of the organic- $\mathrm{N}$ compounds, combinations of these compounds were also added. Samples were taken weekly for analysis of $\mathrm{pH}$, ammonium and nitrate. Formation of nitrite was checked, but it was never detected. Experiments were done in triplicate.

In a second series, the effect of urea on nitrification was studied by comparing nitrate production following equivalent additions of urea and ammonium carbonate. Soil suspensions were prepared as described above. Every other day, during a period of 18 days, either urea $(0.05$ mmol t-1 $)$ and sodium chloride $\left(0.1 \mathrm{mmol} \mathrm{l}^{-1}\right)$ or sodium carbonate $\left(0.05 \mathrm{mmol}^{-1}\right)$ and ammonium chloride $\left(0.1 \mathrm{mmol} \mathrm{l}^{-1}\right)$, respectively, were added. Incubation and sampling conditions were as described above. At the start of the experiment, before the first addition, and on the 20th day of incubation nitrifiers were counted using a MPN method (Chapter 5).

Production of nitrate in urea-enriched suspensions was tested for its sensitivity to nitrapyrin $\left(20 \mathrm{mg} \mathrm{l}^{-1}\right)$.

\section{Isolation of nitrifiers}

An ammonium- and a nitrite-oxidizing bacterium were isolated from the highest positive dilution of MPN enumerations of the fertilized heathland soil (Ah-horizon, 800 NPK plot, Hoorneboegse heide). They were isolated using the dilution procedure described by Schmidt and Belser (1982). Purity was tested by plating on agar $(1.25 \%)$ containing glucose $(0.1 \%)$ peptone $(0.1 \%)$, yeast extract $(0.1 \%)$ and disodium phosphate $(0.015 \%)$. 


\section{Nitrate formation from urea by mixed cultures}

Nitrifiers were tested for their ability to hydrolyse urea at low pH. Nitrosomonas europaea ATCC 19718, Nitrosospira briensis ATCC 25971 and the ammonium-oxidizing isolate AHB1, respectively, were cultured in the presence of the nitrite oxidizing isolate NHB1 in a sterile mineral medium ( $\mathrm{pH} 7.5$ ) containing ammonium sulphate $\left(2.5 \mathrm{mmol} \mathrm{l}^{-1}\right)$ as a substrate. The composition of the mineral medium was the same as described previously (Chapter 5). Ammonium- and nitrite-oxidizers were co-cultured to prevent toxicity of nitrite at low $\mathrm{pH}$. The mixed cultures were incubated at $20{ }^{\circ} \mathrm{C}$ without $\mathrm{pH}$ adjustment. When the $\mathrm{pH}$ had decreased and the nitrifying activities had ceased, the mixed cultures contained 1-2 $10^{6}$ cells $\mathrm{ml}^{-1}$ of both ammonium- and nitrite-oxidizers.

Aliquots of $5 \mathrm{ml}$ of the mixed cultures were transferred into four replicate Erlenmeyer flasks containing $45 \mathrm{ml}$ of sterile mineral medium adjusted to $\mathrm{pH} 4.0$ before autoclaving. Then, $0.5 \mathrm{ml}$ of a solution containing urea ( $100 \mathrm{mmol} \mathrm{^{-1 }}$ ), sterilized by filtration, was added to each flask. The flasks were incubated, without shaking, at $20^{\circ} \mathrm{C}$. During a period of 40 days $\mathrm{pH}$, nitrite, nitrate and ammonium were measured every 4 days.

\section{Analytical procedures}

Concentrations of ammonium, nitrite and nitrate were measured using a Technicon autoanalyzer.

\section{RESULTS}

\section{Effect of organic $N$-compounds on nitrate production in soil suspensions}

Ammonification of the added compounds was completed, except for chitin, within two weeks (Fig. 1). The increase in $\mathrm{pH}$, due to ammonification, was almost the same for the different additions. However, the production of nitrate, which followed ammonification, was not the same: by far the most nitrate was produced in suspensions enriched with urea (Fig. 1). Nitrate production resulted in a decrease of the $\mathrm{pH}$.

When chitin was added ammonium was produced throughout the incubation period. At the end of the incubation period degradation of chitin was still far from complete as at that moment about $0.3 \mathrm{mmol}$ NH4- $\mathrm{N}^{-1}$ was produced instead of the $1 \mathrm{mmol} \mathrm{I}^{-1}$ that theoretically could have been formed.. Apart from urea, production of inorganic nitrogen was also less than $1 \mathrm{mmol} \mathrm{l}^{-1}$ in the other suspensions. This must be attributed to immobilization of nitrogen by heterotrophic micro-organisms growing on the added organic compounds.

Production of nitrate in urea-enriched suspensions was smaller when peptone or oxamide were added (Table 1), which may indicate that these compounds inhibited nitrification. The effect of additions of adenine or chitin were not studied. 

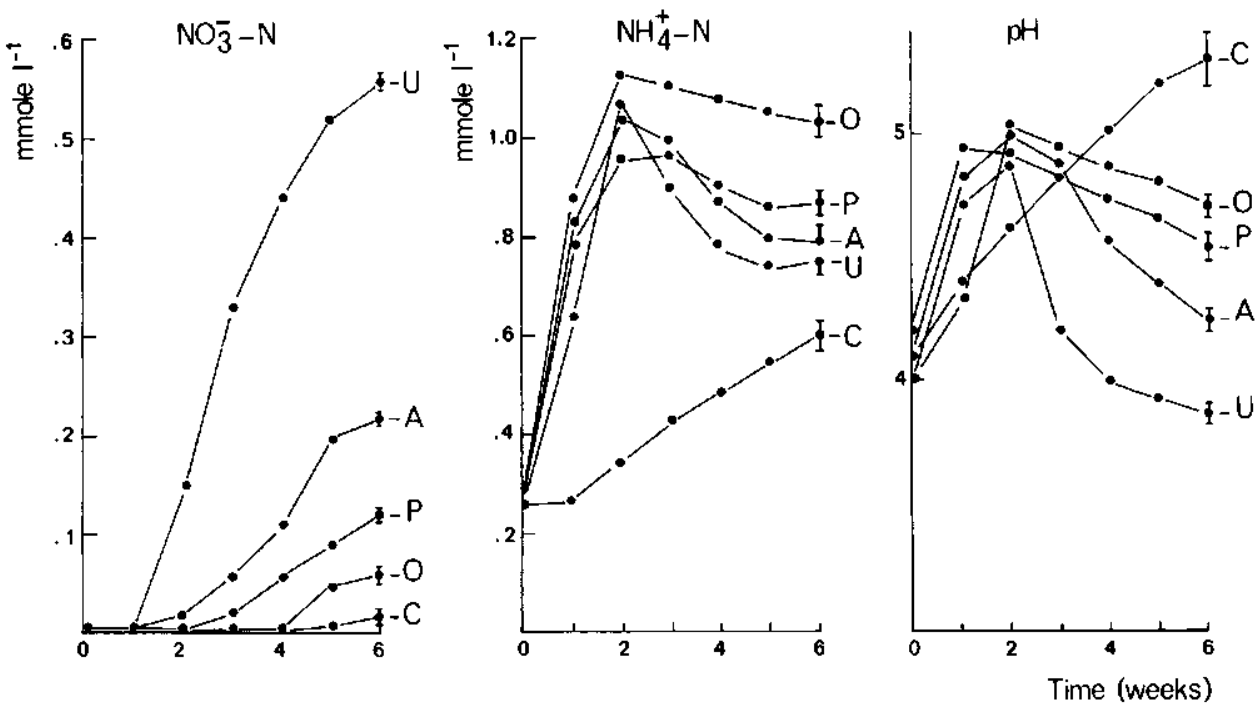

Fig. I Efrect of addition of organic $\mathrm{N}$-compounds on accumulation of ammonium and nitrate in suspensions of a fertilized heathland soil . Urea (U), adenine (A), peptone (P), oxamide (O) and chitin (C) were added in amounts equivalent to $14 \mathrm{mg} \mathrm{N}^{-4}$. Data represent the mean of three replicates. Vertical bars indicate standard deviation.

Table 1. Effect of single and mixed addition of organic N-compounds on nitrate production in suspensions of a fertilized heathland soil

\begin{tabular}{lcc}
\hline Additions $\left(\mathrm{mmol} \mathrm{l}^{-1}\right)$ & $\begin{array}{c}\text { Maximum } \\
\mathrm{pH} \text { reached }\end{array}$ & $\begin{array}{c}\text { Nitrate production } \\
\text { (mmol 1-1 }\end{array}$ \\
\hline $\left.\mathrm{in}_{4} \mathrm{wk}\right)$
\end{tabular}

Numbers in the column followed by different letters are significantly different $(p<0.01)$ as determined by a small-sample t-test 
In suspensions of the heathland soil nitrification was stimulated by urea itself and not by the increase in $\mathrm{pH}$, due to hydrolysis of urea. This became clear from the observation that nitrate production was much higher following addition of urea than after equivalent additions of ammonium hydroxide or ammonium carbonate (Table 1; Fig. 2).
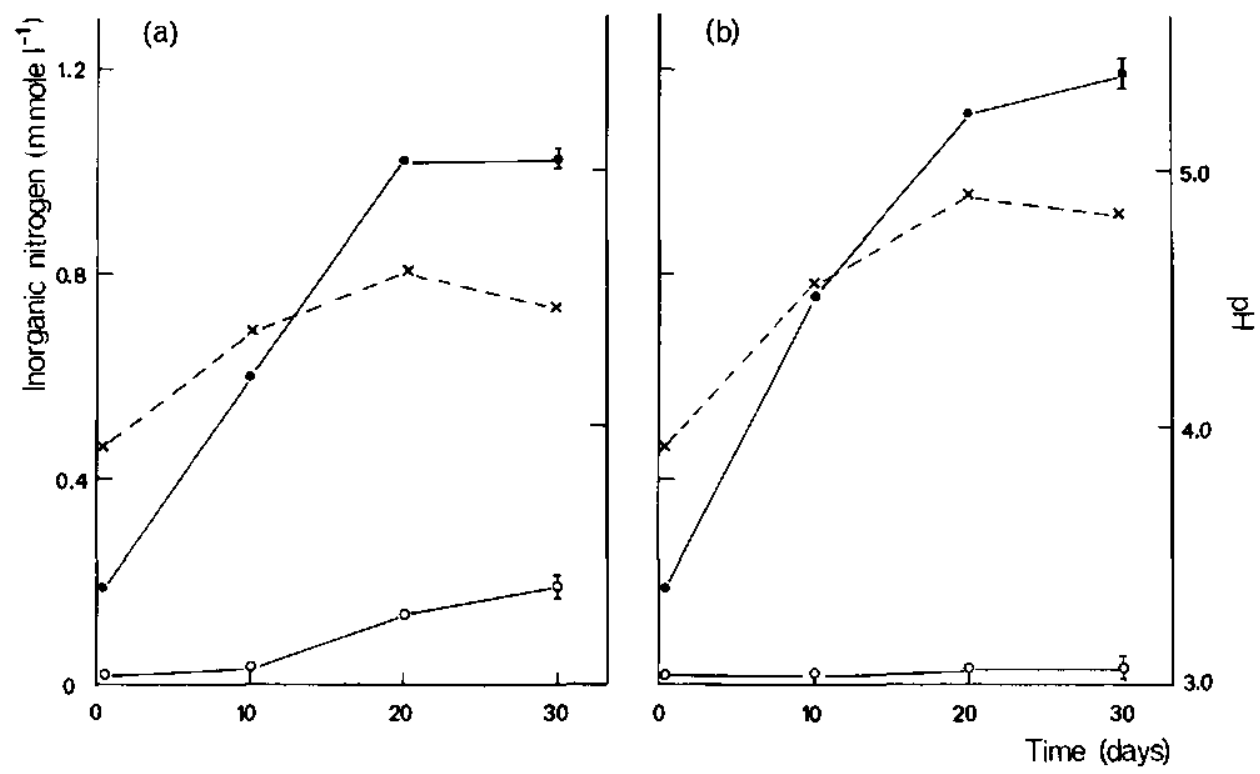

Fig. 2. Efiect of urea and ammonium carbonate on nitrate production in suspensions of a fertilized heathland soil. Urea-treatment (a) consisted of 10 additions of $0.05 \mathrm{mmol}$ urea +0.1 mmol sodium chloride $\mathrm{I}^{-1}$ of suspension. Ammonium carbonate treatment (b) consisted of 10 additions of 0.05 mmol sodium carbonate $+0.1 \mathrm{mmol}$ ammonium chloride $\mathrm{l}^{-1}$ of suspension. The additions were made every other day during the first 18 days of incubation. $\mathrm{pH}(x-x)$ and concentrations of ammonium $(-)$ and nitrate $\left(\mathrm{O}_{-} \mathrm{O}\right)$ are shown. Data represent the mean of three replicates. Vertical bars indicate standard deviation.

In urea-treated suspensions numbers of nitrifiers had increased after 20 days of incubation (Table 2). The increase in numbers of nitrite-oxidizers was much higher than that of ammonium-oxidizers resulting in a yield of $2.8 \times 10^{7}$ and $1.0 \times 10^{5}$ cells of nitrite-oxidizers and ammonium-oxidizers, respectively, $\mu \mathrm{mol}^{-1}$ nitrate produced. The increase of ammonium-oxidizers was observed only when counts were made using a medium of $\mathrm{pH} 7.5$ and not when media of $\mathrm{pH} 6.0$ or 4.5 were used. Counts of nitrite-oxidizers were only made at $\mathrm{pH} 6.5$ because of the instability of nitrite at low $\mathrm{pH}$. In suspensions supplied with ammonium carbonate there was no increase in numbers of ammonium-oxidizers. However, numbers of nitrite-oxidizers did increase resulting in a yield of $2.4 \times 10^{7}$ cells $\mu \mathrm{mol}^{-1}$ nitrate produced. 
Table 2. Efiect of urea (U) and ammonium carbonate (AC) on most probable numbers of nitrifiers in suspensions of a fertilized heathland soil.

\begin{tabular}{cccc}
\hline $\begin{array}{c}\text { Incubation time } \\
\text { (days) }\end{array}$ & Addition & $\begin{array}{c}\text { Ammonium-oxidizers } \\
\left(\times 10^{2} \mathrm{ml}^{-1}\right)\end{array}$ & $\begin{array}{c}\text { Nitrite-oxidizers } \\
\left(\times 10^{4} \mathrm{ml}^{-1}\right)\end{array}$ \\
\hline 0 & $\mathrm{AC}$ & 1.9 & 0.6 \\
0 & $\mathrm{U}$ & 1.9 & 0.6 \\
20 & $\mathrm{AC}$ & 0.2 & 34 \\
20 & $\mathrm{U}$ & 120 & 340 \\
\hline
\end{tabular}

Additions were made as described in the legend of Fig. 2

The contribution of heterotrophs to nitrification in urea-enriched suspensions is probably of minor importance, as nitrate production was completely inhibited by nitrapyrin (Table 3).

Table 3. Effect of nitrapyrin $\left(20 \mathrm{mg} \mathrm{I^{-1 } )}\right.$ on accumulation of ammonium and nitrate $\left(\mathrm{mmol} \mathrm{l}^{-1}\right)$ in suspensions of a fertilized heathland soil supplied with urea $(0.5 \mathrm{mM})$. Data are the mean of three replicates

\begin{tabular}{ccccc}
$\begin{array}{c}\text { Incubation } \\
\text { time } \\
\text { (days) }\end{array}$ & $\mathrm{NH}_{4}^{+}$ & $\mathrm{NO}_{3}^{-}$ & $\mathrm{NH}_{4}^{+}$ & \\
\hline 0 & $0.14(0.02)^{*}$ & 0.00 & $0.14(0.02)$ & $\mathrm{NO}_{3}^{-}$ \\
\hline 6 & $0.83(0.03)$ & $0.28(0.04)$ & $1.08(0.04)$ & 0.00 \\
\hline
\end{tabular}

* standard deviation

\section{Nitrate formation from urea by mixed cultures}

At low $\mathrm{pH}$, mixed cultures of $N$. europaea or $N$. briensis and the nitrite oxidizer isolated from the heathland soil did not produce ammonium or nitrate in a medium containing urea. The $\mathrm{pH}$ of these mixed cultures did not change much throughout the incubation (Fig. 3). However, the $\mathrm{pH}$ of the mixed culture consisting of both the ammonium- and nitrite-oxidizing isolates increased to about 6.6 , followed by a decrease to about 4.5 (Fig. 3). In this culture all urea was converted to equivalent amounts (approx. $1 \mathrm{mmol} \mathrm{1}^{-1}$ ) of ammonium and nitrate. Urea hydrolysis and ammonium oxidation did not proceed simultaneously. At the time when the $\mathrm{pH}$ had increased to about $6,0.25 \mathrm{mmol}^{-1}$ ammonium and $0.05 \mathrm{mmol} \mathrm{l}^{-1}$ nitrate had been produced. Nitrite could not be detected. 


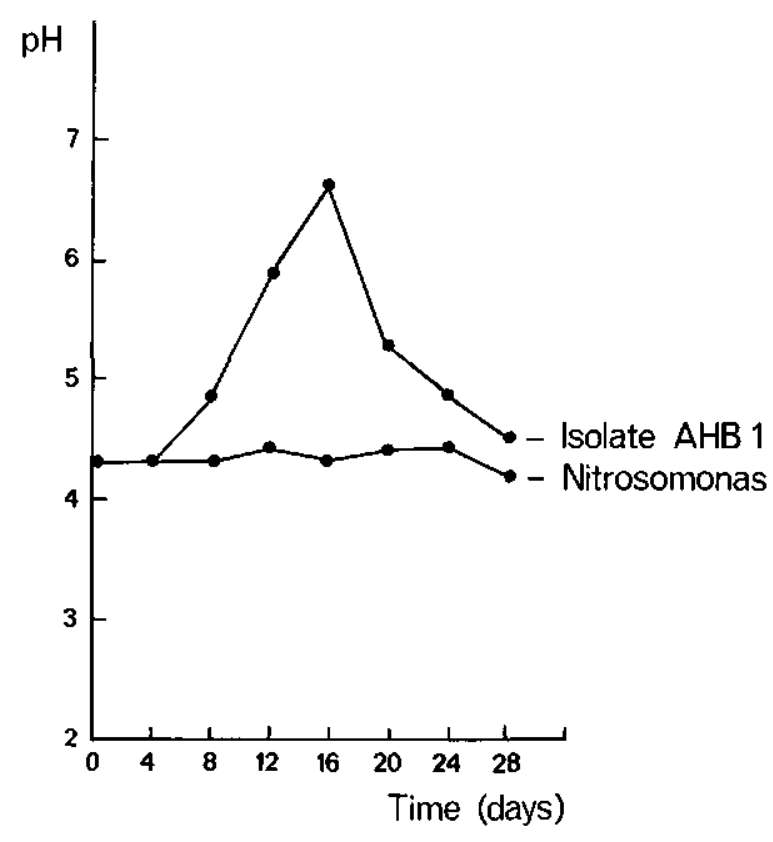

Fig. 3. pH of cultures of Nitrosomonas europaea and an ammonium-oxidizing isolate AHB1, both cultured in the presence of a nitrite-oxidizing isolate NHB1 in an acidic inorganic medium containing urea $(1 \mathrm{mM})$. $\mathrm{pH}$ of cultures of Nutrosospira briensis did not differ from that of cultures of Nitrosomonas europaea.

\section{DISCUSSION}

Acid-sensitive, chemolitho-autotrophic nitrifiers have often been isolated from soils with a low pH (Bhuiya and Walker, 1977; Walker and Wickramasinghe, 1979; Josserand and Cleyet-Marel, 1979; Hankinson and Schmidt, 1984; Martikainen and Nurmiaho-Lassila, 1985) This may imply that these organisms can be active in such habitats. One of the most intriguing questions concerning nitrification in acid soils is the question of how these nitrifiers manage to be active in such soils. It has been proposed that the activities of chemolithotrophic nitrifiers are limited to microsites of relatively high $\mathrm{pH}$ (Overrein, 1967; Hankinson and Schmidt, 1984). The observation that chemolithotrophic nitrification is often stimulated by fertilization with organic $\mathrm{N}$-compounds or calcareous compounds that bring about an increase in the soil pH supports this idea (Weber and Gainey, 1962; Mai and Fiedler, 1983; Martikainen, 1985). Although the increase in the soil $\mathrm{pH}$ by such fertilizations is often small, it is certainly possible that the number of microsites in which chemolithotrophic nitrifiers may be active has increased (Overrein 1967).

In unfertilized soils such microsites are most likely formed by ammonification of soil organic compounds (Kaila, 1954). In this respect it is worth mentioning that 
nitrification has been reported to be associated with net $\mathbf{N}$ mineralization (Vitousek et al., 1982; Robertson, 1982a; Kreitinger et al., 1985). Since heterotrophic nitrification is also expected to be associated with $(\mathrm{N})$ mineralization, there is little unambiguous evidence that acid-sensitive, chemolithotrophic nitrification and $\mathrm{N}$ mineralization are correlated.

In the previous Chapter it is reported that acid-sensitive, chemolithotrophic nitrification in acidic, ammonium-enriched suspensions of a heathland soil occurred only after net ammonification had started. Assuming that the existence of microsites with a relatively high $\mathrm{pH}$ in shaken soil suspensions is rather unlikely, it was proposed that acid-sensitive ammonium-oxidizing bacteria may be active or activated when they are present in proximity to ammonifying micro-organisms where a $\mathrm{pH}$ favourable for nitrification may exist as a result of dissociation of excreted ammonia.

According to this hypothesis, events that will accelerate or increase ammonification will also affect nitrification. However, the addition of several organic-N compounds which increase ammonification had very different effects on nitrification. Considerably more nitrate was produced in suspensions enriched with urea than in suspensions supplied with adenine, peptone, oxamide or chitin. Combined additions of urea and peptone or oxamide were less stimulatory than urea additions only, indicating that nitrification was directly or indirectly inhibited by these compounds. Such inhibition of nitrifiers by organic compounds has often been reported (e.g. Smith and Hoare, 1977). Hence, the inhibitory effect displayed by organic $\mathrm{N}$-compounds may be interfering with the proposed coupling between ammonification and nitrification.

Stimulation of nitrification in soil suspensions by urea was not caused by an increase of the bulk $\mathrm{pH}$ due to urea hydrolysis, as nitrate production was much less at comparable $\mathrm{pH}$ in suspensions enriched with ammonium hydroxide or ammonium carbonate. This observation agrees well with the idea of an ammonificationdependent nitrification. However, the observation that an ammonium-oxidizing bacterium isolated from the heathland soil under study, has the ability to hydrolyse urea at low $\mathrm{pH}$ suggests that urea may directly activate nitrifiers without the presence of an urease-producing, heterotrophic micro-organism.

The fact that nitrate production in suspensions supplied with adenine was higher than in suspensions enriched with peptone, oxamide and chitin may also be explained as an urea-effect, since urea is one of the products of purine degradation (Ladd and Jackson, 1982).

Two ATCC strains of the genera Nitrosomonas and Nitrosospira showed no urease activity under the conditions tested. As both strains were cultured in the presence of the nitrite-oxidizing isolate NHB1, it is obvious that hydrolysis of urea in a mixed culture of both the heathland soil isolates was caused by the ammonium-oxidizer AHB1. To the best of our knowledge, the ability to hydrolyse urea at low $\mathrm{pH}$ has never been reported before for ammonium-oxidizing bacteria. In contrast to pure culture studies both urea hydrolysis and ammonium oxidation in shaken suspensions proceeded under acid conditions $(\mathrm{pH}<5)$. The mechanism by which urea activates acid-sensitive, ammonium-oxidizing chemolithotrophs at low $\mathrm{pH}$ has yet to be elucidated. 
The urease-positive ammonium-oxidizer was isolated from the highest positive dilution of a MPN enumeration of the fertilized heathland soil. The mixed fertilizer that has been applied contained ammonium nitrate, but no urea. Therefore, it has to be examined whether or not ammonium-oxidizers do exhibit urease-activity when they are nitrifying in acid heathland soils. One can imagine that the isolate's ability to hydrolyse urea enables this bacterium to respond rapidly when conditions favourable for nitrification arise, for instance, when such conditions are created by excrement of soil animals that contain products of purine degradation e.g. uric acid and urea. This would imply that the activities of soil animals are of great importance for acid-sensitive nitrification in acid soils.

It also would be interesting to know whether the ability to hydrolyse urea is common among ammonium-oxidizers that have been isolated from acid soils. It seems not unlikely that urea-positive ammonium-oxidizers will be selected in urea-fertilized, acid soils where nitrate production is often found to be increased. 


\section{CHAPTER VII}

\section{UREOLYTIC NITRIFICATION AT LOW PH BY NITROSOSPIRA SPEC.}

W. DE BOER AND H.J. LAANBROEK

Published in Archives of Microbiology: 152 (1989) 178-181 


\begin{abstract}
An ureolytic ammonium-oxidizing chemolithotroph belonging to the genus Nitrosospira was shown to nitrify at $\mathrm{pH} 4.5$ in a $\mathrm{pH}$-stat with urea as a substrate. With ammonium as the sole substrate nitrification did not occur at $\mathrm{pH}$ values below 5.5. Nitrosomonas europaea ATCC 19718 and Nitrosospira briensis ATCC 25971 did not possess urease activity. The results indicate that ureolytic ammonium-oxidizing bacteria may contribute to nitrate production in acid soils.
\end{abstract}

\title{
INTRODUCTION
}

The occurrence of nitrification in acid soils $(\mathrm{pH}<4.5)$ has often been reported. Yet, the mechanism of nitrate formation in these soils has remained obscure. Depending on the type of acid soil examined, heterotrophic or autotrophic mico-organisms have been thought to be responsible for nitrate production (Weier and Gilliam 1985; Killham 1986). Recently, Hankinson and Schmidt (1988) reported the isolation of an acidophilic nitrite-oxidizing bacterium belonging to the genus Nitrobacter. All ammonium-oxidizing chemolithotrophs that have been isolated from acid soils so far are acid-sensitive: these organisms lack the ability to nitrify in liquid batch cultures below pH 6 (Hankinson and Schmidt, 1984; Martikainen and Nurmiaho-Lassila, 1985). Therefore, Hankinson and Schmidt $(1984,1988)$ assumed that chemolithotrophic ammonium-oxidation may be restricted to circumneutral microsites in the otherwise acid soil whereas chemolithotrophic nitrite-oxidation may not be limited to such sites. However, it can not be excluded that ammonium oxidation in acid soils is caused by unknown chemolithotrophic acid-tolerant or even acidophilic bacteria.

In the previous Chapter it was demonstrated that urea stimulates nitrification at low $\mathrm{pH}$ in suspensions of an acid heathland soil. Furthermore, an acid-sensitive chemolithotrophic ammonium-oxidizing bacterium isolated from that soil was observed to be urease-positive. Therefore, it was proposed that urea may be important in stimulating acid-sensitive, chemolithotrophic ammonium-oxidation. In this Chapter it is shown that the ureolytic, ammonium-oxidizing bacterium is able to nitrify at low $\mathrm{pH}$ in a mineral medium containing urea.

\section{MATERIAL AND METHODS}

\section{Organisms and growth conditions}

The ammonium-oxidizing strain used in this study was a strain isolated from an acid heathland soil (Chapter 6). On the basis of its morphology (see the Results section) it is further referred to as Nitrosospira strain AHB1. In pH-stat experiments Nitrosospira strain AHB1 was co-cultured with a nitrite-oxidizing bacterium, Nitrobacter strain NHB1, isolated from the same heathland soil. The strains 
Nitrosospira briensis ATCC 25971 and Nitrosomonas europaea ATCC 19718 were used as a comparison. Ammonium-oxidizing strains were grown in mineral medium containing $330 \mathrm{mg} \mathrm{l}^{-1}\left(\mathrm{NH}_{4}\right)_{2} \mathrm{SO}_{4}$. The composition of the mineral medium was (per liter): $\mathrm{KH}_{2} \mathrm{PO}_{4}, 100 \mathrm{mg} ; \mathrm{MgSO}_{4} .7 \mathrm{H}_{2} \mathrm{O}, 40 \mathrm{mg} ; \mathrm{CaCl}_{2}, 15 \mathrm{mg} ; \mathrm{FeSO}_{4} .7 \mathrm{H}_{2} \mathrm{O}, 2.5 \mathrm{mg}$; $\mathrm{Na}_{2}$-EDTA $3.3 \mathrm{mg} ; \mathrm{MnCl}_{2}, 0.2 \mathrm{mg} ; \mathrm{NaMoO}_{4} .2 \mathrm{H}_{2} \mathrm{O}, 0.1 \mathrm{mg} ; \mathrm{ZnSO}_{4} .7 \mathrm{H}_{2} \mathrm{O}, 0.1 \mathrm{mg}$; $\mathrm{NiCl}_{2} \cdot 6 \mathrm{H}_{2} \mathrm{O}, 20 \mu \mathrm{g} ; \mathrm{CuSO}_{4} \cdot 5 \mathrm{H}_{2} \mathrm{O}, 20 \mu \mathrm{g} ; \mathrm{CoCl}_{2} \cdot 6 \mathrm{H}_{2} \mathrm{O}, 2 \mu \mathrm{g}$. The $\mathrm{pH}$ was adjusted wih $\mathrm{NaOH}$; after autoclaving it was 7.0-7.5. Incubation was at $20^{\circ} \mathrm{C}$ without shaking and without $\mathrm{pH}$ adjustment. The strains were subcultured every three weeks by inoculating $50 \mathrm{ml}$ medium with $1 \mathrm{ml}$ of an outgrown culture. Outgrown cultures were used as inocula for all experiments. Purity was tested regulary by inoculating $5 \mathrm{ml}$ of sterile $0.1 \%$ glucose-peptone-yeast extract medium ( $\mathrm{pH} \mathrm{7.5)} \mathrm{and} \mathrm{subsequent}$ incubation at $20^{\circ} \mathrm{C}$. The cultures were considered to be pure when no turbidity became visible within 3 weeks.

\section{Determination of urea-hydrolysis}

Hydrolysis of urea by ammonium-oxidizing bacteria at neutral $\mathrm{pH}$ was examined by inoculating $50 \mathrm{ml}$ mineral medium $(\mathrm{pH} 7)$, containing $1 \mathrm{mmol} \mathrm{l}^{-1}$ urea (sterilized by filtration), with $1 \mathrm{ml}$ of outgrown cultures of the ammonium-oxidizing bacteria studied. The inoculum contained 1 - 2 million cells. Incubation was without shaking at $20^{\circ} \mathrm{C}$ for 4 weeks and the production of nitrite and ammonium was determined. These experiments were performed in triplicate.

As urea-hydrolysis was only found to occur when Nitrosospira strain AHB1 cells were used, further experiments were performed with this strain. Namely whether this strain was able to hydrolyse substrates that may precede urea during the degradation of nitrogen-containing organic compounds, e.g. adenine, xanthine, uric acid, allantoin, allantoic acid, ureidoglycolate and arginine. Nine $\mathrm{ml}$ of filter-sterilised basal medium ( $\mathrm{pH} 4.8$ ) containing $0.1 \mathrm{mmol}^{-1}$ of one of these compounds was inoculated in triplicate with $1 \mathrm{ml}$ of outgrown culture of Nitrosospira strain AHB1. After 4 weeks of incubation without shaking at $20^{\circ} \mathrm{C}$ the production of ammonium and nitrite was determined.

\section{pH-stat experiments}

It was studied whether urea-hydrolysis and nitrification by Nitrosospira strain AHB1 could proceed simultaneously at low $\mathrm{pH}$ in a $\mathrm{pH}$-stat. The experiments were performed using a Biostat $\mathrm{M}$ fermentor (Braun, Melsungen, West-Germany). In the culture-vessel $900 \mathrm{ml}$ sterile mineral medium was inoculated with $100 \mathrm{ml}$ of a 20 day-old mixed culture of Nitrosospira strain AHB1 and Nitrobacter strain NHB1 grown in mineral medium $(\mathrm{pH} 7.5)$ containing $0.5 \mathrm{mM}\left(\mathrm{NH}_{4}\right)_{2} \mathrm{SO}_{4}$. The inoculum contained 1-2 million cells $\mathrm{ml}^{-1}$ of the two organisms as was determined using an MPN-method (Chapter 5). Experiments were performed with mixed cultures of the nitrifiers in order to prevent a possible toxic effect of nitrite at low $\mathrm{pH}$. In preliminary experiments Nitrobacter strain NHB1 did not show any urea-hydrolysing activity. A filter-sterilized urea solution was added to the mixed culture (final concentration $1-1.25 \mathrm{mmol} \mathrm{l}^{-1}$ ). Temperature and air-saturation were kept at $20^{\circ} \mathrm{C}$ 
and $80 \%$, respectively. The $\mathrm{pH}$ was kept constant at $4.5,5.0$ or 5.5 , respectively, by autotitration with either $0.1 \mathrm{mmol} \mathrm{l}^{-1} \mathrm{NaOH}$ or $0.05 \mathrm{mmol} \mathrm{l}^{-1} \mathrm{Na}_{2} \mathrm{CO}_{3}$ plus 0.05 mmol $\mathrm{l}^{-1} \mathrm{H}_{2} \mathrm{SO}_{4}$. Every second day samples were taken for determination of urea, ammonium, nitrite and nitrate. The oxidation of ammonium (added as 1 - 1.25 mmol $\left.\mathrm{l}^{-1}\left(\mathrm{NH}_{4}\right)_{2} \mathrm{SO}_{4}\right)$ was also examined at the same $\mathrm{pH}$. All $\mathrm{pH}$-stat experiments were done at least twice.

\section{Analytical methods}

Ammonium, nitrite and nitrate were determined colorimetrically using a Technicon Traacs 800 autoanalyzer (Technicon Instr. Corp., Tarrytown, USA). Urea was determined as ammonium after hydrolysis by urease from jack beans (Sigma, St. Louis, USA) in $2.5 \mathrm{mM}$ phosphate buffer ( $\mathrm{pH} \mathrm{6.8)} \mathrm{containing} 5 \mathrm{U} \mathrm{ml}^{-1}$ urease.

\section{Scanning electron microscopy}

Nitrosospira cells cultured in basal medium containing $330 \mathrm{mg}\left(\mathrm{NH}_{4}\right)_{2} \mathrm{SO}_{4}$ were concentrated by centrifugation $(18000 \mathrm{x}$ g) to about 100 million cells per ml, washed twice in mineral medium and subsequently fixed in $2 \%$ glutaraldehyde in $0.1 \mathrm{M}$ cacodylate buffer for $2 \mathrm{~h}$ at $0{ }^{\circ} \mathrm{C}$. Dehydration was achieved using a two step ethanol series (50 and $70 \%$ ) and a subsequent treatment with $32 \%(\mathrm{w} / \mathrm{v})$ dimethoxy propane (DMP) in $2 \% \mathrm{HCl}$. The cells were coated with gold and examined in a I.S.I. DS130 scanning electron microscope.

\section{RESULTS AND DISCUSSION}

\section{Morphology}

As can be seen from Fig. 1. the isolated ammonium-oxidizing strain AHB1 is a spiral-shaped bacterium with a length of about $1 \mu$. Therefore, this isolate probably belongs to the genus Nitrosospira. Tentatively, it will be referred to as Nitrosospira strain AHB1. Nitrosospira seems to be commonly present in acid soils since it has often been isolated from such soils (Walker and Wickramasinghe 1979; Hankinson and Schmidt 1984; Martikainen and Nurmiaho-Lassila 1985).

\section{Urea hydrolysis by ammonium-oxidizing bacteria at neutral $\mathrm{pH}$}

Earlier experiments had shown that among the three ammonium-oxizing strains studied, Nitrosospira strain AHB1 was the only one that could hydrolyse urea at low $\mathrm{pH}$ (Chapter 6). Current experiments showed that also at neutral $\mathrm{pH}$ urea is only hydrolysed by the newly isolated Nitrosospira strain. Yet, it is doubtful whether the ability to hydrolyse urea may be used to distinguish between ammonium-oxidizing bacteria present in acid soils and those isolated from other environments. Most of the ammonium-oxidizing strains present in the Hamburg culture collection were 
found to be urease positive (H. Koops, pers. comm.). Furthermore, some of the ammonium-oxidizing strains, isolated from acid Scottish soils, that were found to be urease-positive at neutral $\mathrm{pH}$ could not hydrolyse urea below $\mathrm{pH} 6$ (S.M. Allison, University of Aberdeen, pers. comm.).

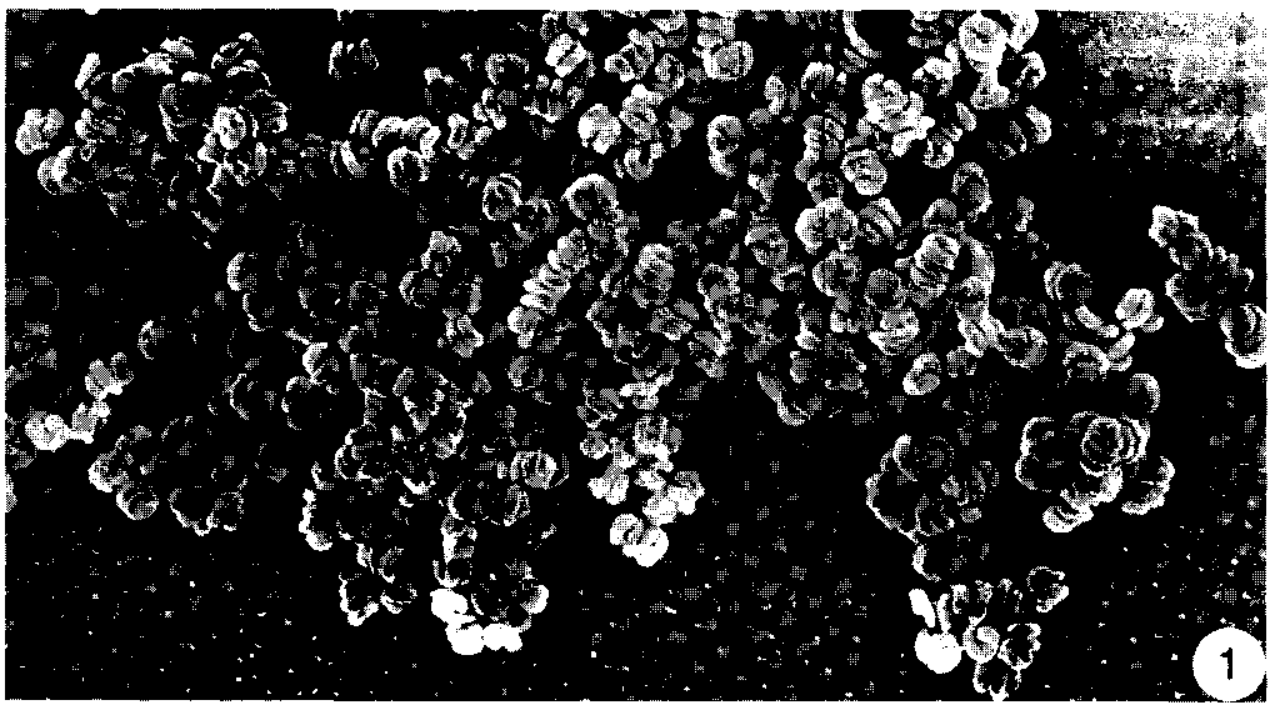

Fig. 1. Scanning electron micrograph of Nitrosospira strain AHB1

From the substrates that can be degraded to urea only, allantoate and ureidoglycolate led to nitrite production by Nitrosospira strain AHB1 at pH 4.8. However, production of ammonium and nitrite from allantoate and ureidoglycolate is probably due to the chemical hydrolysis of the compounds at low $\mathrm{pH}$. One of the major non-enzymic products of hydrolysis of allantoate below pH 6 is urea (Vogels and Van der Drift 1969). Furthermore, no allantoicase activity could be demonstrated in cells grown on allantoate.

At the moment it is not known how the production of urease by Nitrosospira strain AHB1 is regulated. There is some evidence that the formation of urease does not require induction by urease itself as urea was immediately hydrolysed by concentrated ammonium-grown cells (data not presented). Still, the rate of urea hydrolysis by urea-grown cells was found to to be higher than by ammonium-grown cells indicating that urea may regulate the amount of urease that is produced. It is tempting to explain constitutive formation of urease as an adaption of Nitrosospira strain AHB1 to react immediately whenever conditions for ureolytic nitrification become favourable.

Chloramphenicol, an inhibitor of de novo enzyme synthesis could not be used to show constitutive formation of urease as it did not inhibit the growth of Nitrosospira AHB1. 
Urea is hydrolysed in bacteria by a periplasmic or cytoplasmic urease (McLean et al., 1986; Jahns et al., 1988). In the latter case urea has to be translocated across the cell membrane. Since urea is a rather small and uncharged molecule it is generally assumed that urea passes the cell-membrane by diffusion. Recently, it was shown that at least in some bacteria urea translocation is a carrier-mediated, energy-dependent process (Jahns et al., 1988). Furthermore it was calculated that only when urea is present at high concentrations $(>100 \mathrm{mM})$ diffusion may be sufficient to satisfy the nitrogen requirement of heterotrophs. Hence, it is possible that urea is also actively translocated in Nitrosospira strain AHB1 cells when its concentration is $1 \mathrm{mmol} \mathrm{l}^{-1}$ or less. This implies that the ability to hydrolyse urea may be determined both by the activity of a transport-system and the activity of urease. It was observed that a heat treatment $\left(10 \mathrm{~min} 60^{\circ} \mathrm{C}\right)$ of Nitrosospira strain AHB1 cells completely reduced the ability to hydrolyse urea. However urease activity was still detectable in sonified cell suspensions (data not presented). This may be interpreted as an indication of the destruction by the heat treatment of a urea transport-system but not of the urease itself. That the urease of Nitrosospira strain AHB1 seems to be thermo-stabile is not surpising since this is also the case for many other bacterial ureases (Seneca et al., 1962; Jahns et al., 1988).

\section{pH-stat experiments}

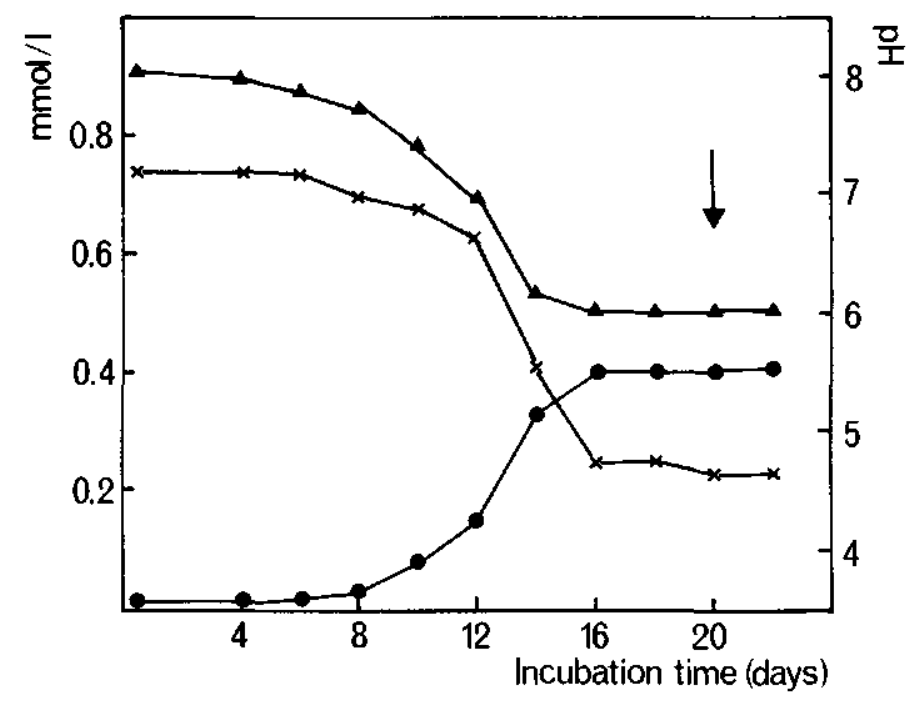

Fig. 2. Ammonium-oxddation in mixed batch cultures of Nitrosaspira strain AHB1 and Nitrobacter strain NHB1. The changes in pH $(\rightarrow x-)$, ammonium- $(-\infty)$ and nitrate-concentration $(-\infty)$ are shown. After 20 days of incubation (arrow) at $20^{\circ} \mathrm{C}$ these cultures were used as inocula for pH-stat experiments. At that moment, the cultures contained $1.210^{6}$ cells/ml of both the ammoniumoxidizing and the nitrite-oxidizing bacteria. 
In mixed batch cultures of Nitrosospira strain AHB1 and Nitrobacter strain NHB1, nitrate production ceased after 16-18 days of incubation (Fig. 2.). By then, the $\mathrm{pH}$ had dropped to 4.7. In similar mixed cultures of the other ammonium-oxidizing bacteria studied and Nitrobacter strain NHB1, the $\mathrm{pH}$ never fell below 5.8. Hence, it seems that Nitrosospira AHB1 cells are better adapted to continue ammonium-oxidation under acid conditions.

With ammonium as the sole substrate nitrate was produced in $\mathrm{pH}$-stat experiments at $\mathrm{pH} 5.5$ but not at $\mathrm{pH} 5.0$ or 4.5 . With urea as substrate nitrate production was found to occur in all pH conditions studied (Fig. 3., 4., 5.). At pH 5.5 nitrate production was much faster with urea than with ammonium (Fig. 3.); both with urea and ammonium all substrate was converted to nitrate. Urea-hydrolysis was completed within 14 days; at that moment the production of ammonium and nitrate was about 1.5 and $1.0 \mathrm{mmol}^{-1}$, respectively.

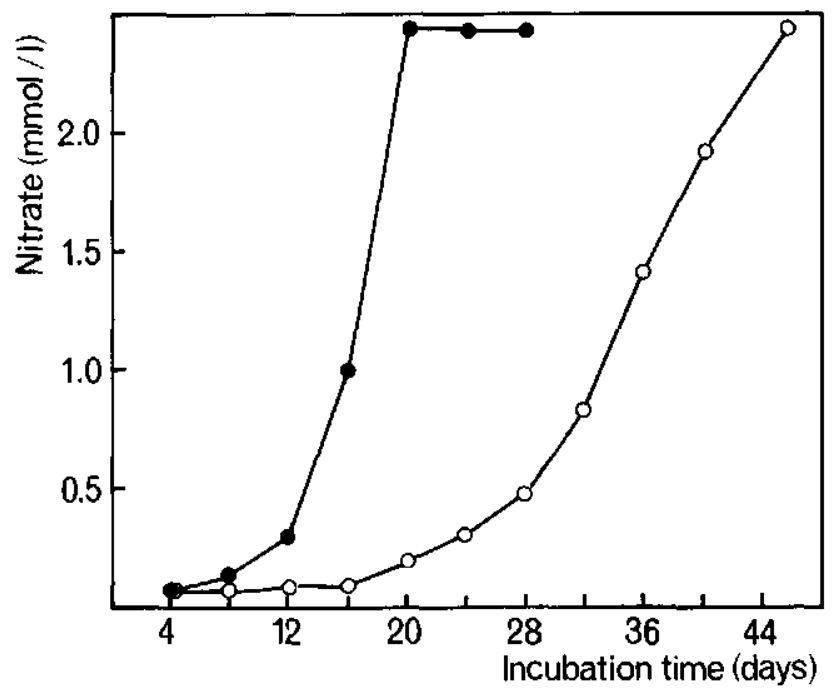

Fig. 3. Nitrate production by a mixed culture of Nitrosopira strain AHB1 and Nitrobacter strain NHB1 in a $\mathrm{pH}$-stat at $\mathrm{pH} 5.5$. At the start of the experiment the culture medium contained $1.25 \mathrm{mM}$ urea $(-\rightarrow)$ or $1.25 \mathrm{mM}$ ammonium sulphate $(-\infty)$

Also at pH 5 urea was completely hydrolysed within 14 days (Fig. 4). After urea-hydrolysis was completed production of nitrate continued for a period of 6 days but then it stopped although ammonium was still available (Fig. 4). At pH 4.5 urea hydrolysis was much slower than at $\mathrm{pH} 5.0$ or 5.5 ; nitrate was produced only during the period when urea was hydrolysed (Fig. 5.). 


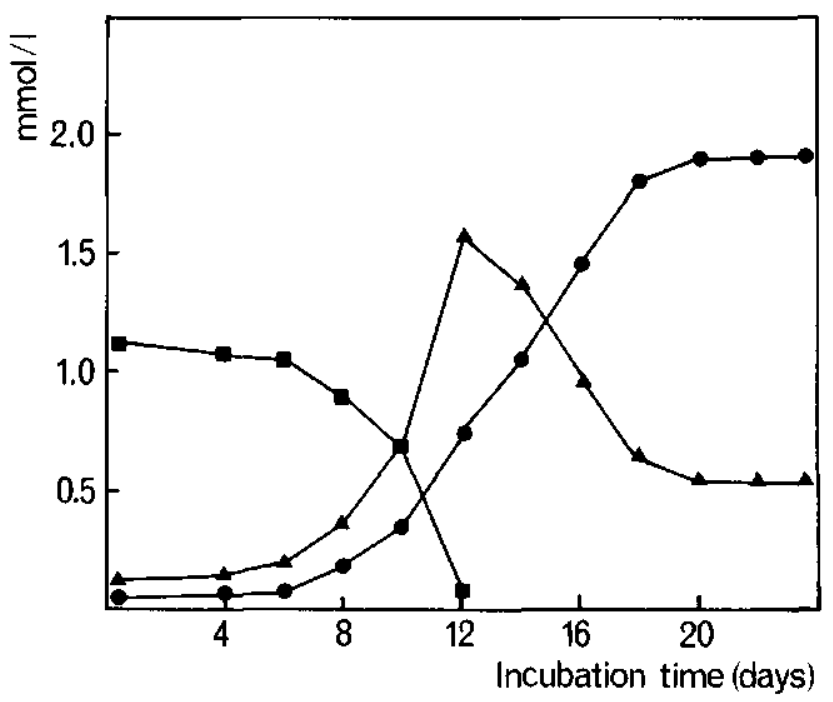

Fig. 4

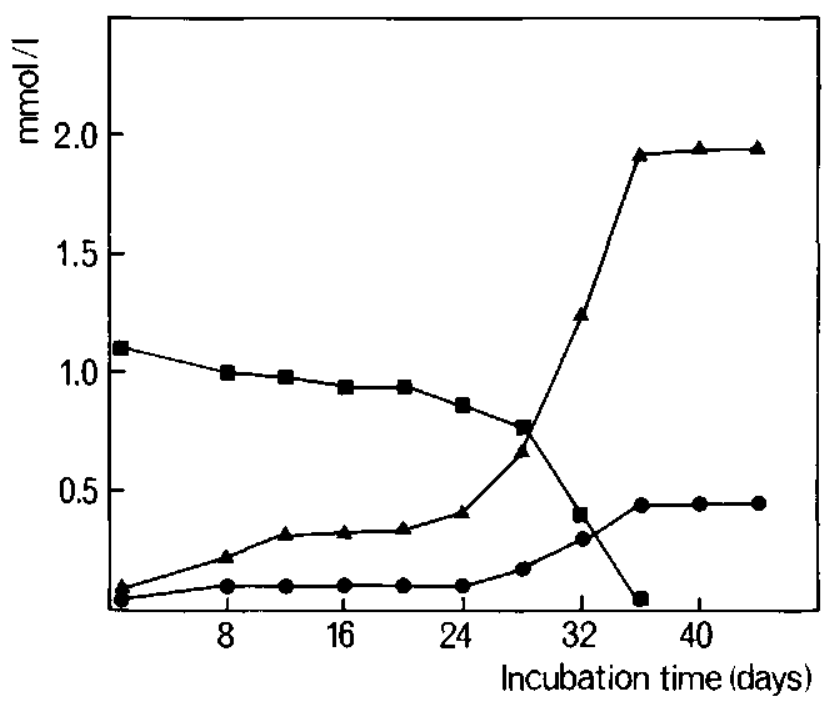

Fig. 5

Fig. 4 and 5. Urea-hydrolysis and nitrification by a mixed culture of Nitrosospira strain AHB1 and Nitrobacter strain NHB1 in a pH-stat at pH 5 (Fig. 4) or pH 4.5 (Fig. 5). The changes in the concentration of urea $(--)$, ammonium $(-\rightarrow)$ and nitrate $(--)$ are shown.

These results clearly show that the ureolytic, chemolithotrophic ammoniumoxidizing Nitrosospira strain AHB1 can nitrify at low pH provided urea is present. The mechanism by which urea activates the cells is not yet understood. In contrast 
to ammonium, at low $\mathrm{pH}$ urea may provide the membrane-bound enzyme ammonia mono-oxygenase with ammonia, which has been reported to be the actual substrate for this enzyme (Wood 1986). Thus, it can be imagined that oxidation at low pH with ammonium as the sole substrate is not possible because the cells are not able to maintain a high internal $\mathrm{pH}$ which will be necessary to provide the enzyme with ammonia. The observation that nitrification can proceed for some time at $\mathrm{pH} 5$ but not at $\mathrm{pH} 4.5$ after urea had been hydrolysed, may be the result of a difference in energy requirement to maintain a sufficiently high internal $\mathrm{pH}$ at both external $\mathrm{pH}$ values. In this respect it is worth mentioning that only urea-hydrolysis but no nitrification was measured when cells of Nitrosospira strain AHB1 and Nitrobacter strain NHB1 were co-cultured at $\mathrm{pH} 5$ in mineral medium containing $1 \mathrm{mmol} \mathrm{l}^{-1}$ urea and $1 \mathrm{mmol} \mathrm{l}^{-1}$ acetate. At this $\mathrm{pH}$ undissociated acetic acid ( $\mathrm{pKa}=4.75$ ) will enter the cells by unspecific diffusion decreasing the cytoplasmic $\mathrm{pH}$ (Booth 1985).

In none of the $\mathrm{pH}$-stat experiments nitrite accumulated in detectable amounts. This implies that Nitrobacter strain NHB1 efficiently oxidized nitrite even at pH 4.5. The optimum $\mathrm{pH}$ for this nitrite-oxidizing bacterium is unknown at the moment, but it is obvious that this organism is adapted to be active in the acid soil from which it was isolated. Recently, Hankinson and Schmidt (1988) reported the existence of an acidophilic nitrite-oxidizing bacterium that was isolated from an acid forest soil. Therefore, acid-tolerant, chemolithotrophic nitrite oxidation is possibly a wide-spread phenomenon.

For the time being we don't know to what extent ureolytic, chemolithotrophic nitrification contributes to nitrate production in acid soils. Still, it is evident that it may occur in acid soils as it was found that urea stimulated nitrate production by chemolithotrophic bacteria in suspensions of heathland soil (Chapter 6). Hence, urea input may be important to determine the activity of acid-sensitive, chemolithotrophic ammonium-oxidizing bacteria in acid soils.

\section{Acknowledgements}

We wish to thank Dr M. Veenhuis and J. Zagers (Laboratory for Electron Microscopy, Biological Centre, University of Groningen) for preparing the electron micrographs. 


\section{CHAPTER VIII}

\section{GENERAL DISCUSSION, CONCLUSIONS AND PERSPECTIVES}




\section{Ammonium-oxidation in heathland soils}

In the previous chapters it has been argued that chemolithotrophic bacteria are most likely to be responsible for the production of nitrate in Dutch heathland soils. Using incubations of suspensions it appeared that nitrate production was either acid-sensitive or acid-tolerant (Chapters 3 and 4). As accumulation of nitrite was never detected during these experiments, the rate-limiting step of nitrate production is apparently ammonium-oxidation at all $\mathrm{pH}$ conditions studied ( $\mathrm{pH} \mathrm{4-6).} \mathrm{It} \mathrm{can} \mathrm{be}$ argued that in suspensions of low $\mathrm{pH}$, nitrite will not accumulate because of the instability of this compound under acid conditions. However, this can be excluded because nitrite immediately started to accumulate after the addition of chlorate, which is an inhibitor of nitrite-oxidation (undescribed experiment). Hence, a better knowledge of the in situ conditions that are required for ammonium-oxidizing bacteria to be active in acid heathland soils will lead to a better insight into the nitrate production in these soils.

Information on the growth characteristics of ammonium-oxidizing bacteria can be obtained from incubations of soil samples, soil suspensions and enrichment cultures. For instance, the inhibiting effect of several compounds can be studied without using pure cultures. However, many questions concerning the ecology and physiology of these bacteria can only be answered when pure cultures are studied. It is clear, that without the isolation of Nitrosospira strain AHB1, it's ability to hydrolyse urea could not have been detected. Unfortunately, the isolation of chemolithotrophic nitrifying bacteria is time consuming. Moreover, isolation-techniques, generally used, may not be suitable for the isolation of all ammonium-oxidizing bacteria. In the course of this study only one acid-sensitive ammonium-oxidizing strain was isolated. Therefore, for the time being, ideas concerning the functioning of ammonium-oxidizing chemolithotrophs in heathland soils are very speculative. It is however worthwhile making these speculations as they can serve as a base for future research.

Next to the micro-site concept (Chapter 1) two additional proposals have been made to explain activity of acid-sensitive, chemolithotrophic ammoniumoxidizing bacteria in acid soils. The first proposal (Chapter 5) deals with the activation of acid-sensitive ammonium-oxidizing chemolithotrophs, at low $\mathrm{pH}$, by ammonia diffusing from an ammonifying micro-organism into the ammonium-oxidizing bacterium (Fig. 1). It is possible that the energy-costs of ammonium-transport and regulation of cytoplasmic $\mathrm{pH}$ are too high to allow oxidation of ammonium by acjd-sensitive ammonium-oxidizing chemolithotrophs at a low external $\mathrm{pH}$ (Fig. 1, step 1). Diffusion of ammonia into the ammonium-oxidizing cell may supply the enzyme ammonia mono-oxygenase with substrate without additional costs for transport of ammonium or internal $\mathrm{pH}$ regulation (Fig. 1, step 2). The energy that is liberated by the oxidation of ammonia may partly be used for the transport of ammonium (Fig. 1, step 3). Finally, the ammonium-oxidizing cell is expected to become inactive again when the stimulating effect of ammonia has disappeared. Clearly, evidence for the existence of such a mechanism can only be given by studying mixed cultures of ammonifying micro-organisms and ammonium-oxidizing bacteria at low $\mathrm{pH}$ under $\mathrm{pH}$-controlled conditions. 


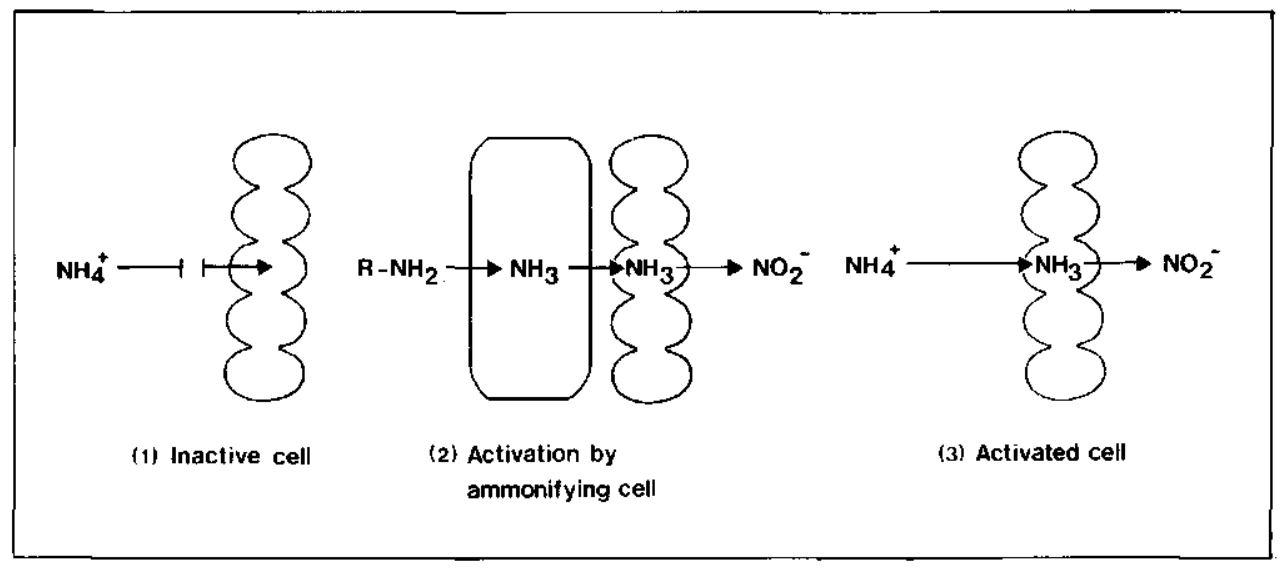

Fig. 1. Possible mechanism for the activation of acid-sensitive, ammonium-oxidizing bacteria by ammonifiers at low pH.

The second proposal deals with the activation of ureolytic, ammoniumoxidizing bacteria by urea (Fig. 2). The starting-point for this proposal is the same as the for the above (Fig. 2, step 1). If urea is produced in the vicinity of an ammonium-oxidizing cell this compound is probably actively transported into the cytoplasm where it is hydrolysed (Chapter 7). Hydrolysis of urea in the cytoplasm may supply the enzyme ammonia mono-oxygenase with ammonia without additional costs for internal pH regulation (Fig. 2, step 2). Similar to the above the energy yielded by the oxidation of ammonia may allow the cells to nitrify for a while with ammonium as substrate at a low external pH (Fig. 2, step 3).

The possibility of ureolytic nitrification in an acid medium by an otherwise acid-sensitive bacterium has been shown (Chapter 7). However, it is not clear to what extent activation by urea can occur in situ because the amount and distribution of urea production in heathland soils is not known.

Both proposed mechanisms may explain activity of acid-sensitive, ammonium-oxidizing chemolithotrophs in acid soil without the need to assume the existence of micro-sites with a relatively high $\mathrm{pH}$. The proposed mechanisms of activation however cannot be distinguished easily from activation in a micro-site with a suitable $\mathrm{pH}$, because both local intensive urea-hydrolysis and - ammonification also give rise to such micro-sites. 


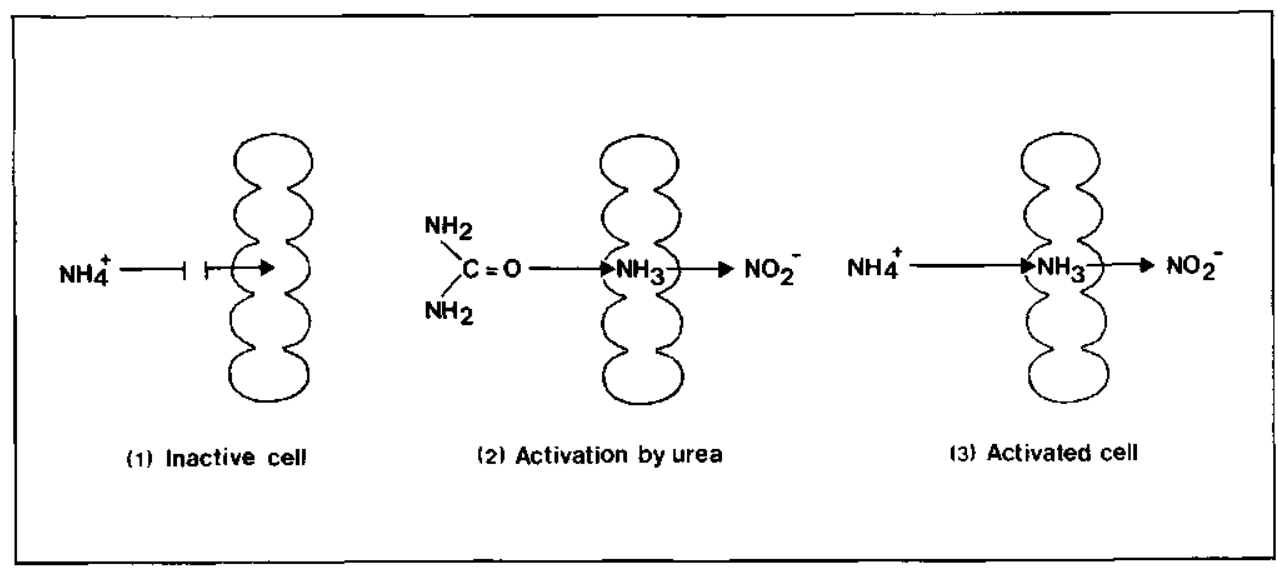

Fig. 2. Possible mechanism for the activation of acid-sensitive, ammonium-oxidizing bacteria by urea at low pH.

Whereas the acid-sensitive ammonium-oxidizing chemolithotrophs appear to be 'opportunity' micro-organisms that require special conditions to be active in an acid soil, the newly discovered acid-tolerant ammonium-oxidizing chemolithotrophs can be active with ammonium as a substrate at low $\mathrm{pH}$ values $(\mathrm{pH}>3)$. However, it appears that these bacteria also need special conditions to be active at low $\mathrm{pH}$ because $5 \mu$-filtrates of enriched suspensions were in a liquid medium free of humus particles only active at $\mathrm{pH} 6$ but not at $\mathrm{pH} 4$ (undescribed experiment). However, in a liquid medium that contained pasteurized humus, nitrate production at $\mathrm{pH} 4$ occured after inoculation with $5 \mu$-filtrate. Preliminary results indicate that the effect of humus is specific, because additions of other solid substrates e.g. polystyrene ion-exchange resins or sand could not bring about production of nitrate in liquid media at $\mathrm{pH} 4$ after inoculation with $5 \mu$-filtrate. At present a suitable explanation of the effect of humus cannot be given. Future research should focus on the following possibilities:

-(1) Acid-tolerant ammonium-oxidizing chemolithotrophs may only be active at low $\mathrm{pH}$ if they are attached to humus particles.

-(2) An unknown growth factor supplied by humus may be necessary to allow acid-tolerant ammonium-oxidizing chemolithotrophs to be active at low $\mathrm{pH}$.

-(3) Detoxification by humus of some nitrification product at low $\mathrm{pH}$ is required for acid-tolerant ammonium-oxidizing chemolithotrophs to be active.

As both acid-sensitive and acid-tolerant ammonium-oxidizing bacteria may be present in the same heathland soil it can be asked which specific micro-niches are occupied by both groups of bacteria. Much additional information on the growth characteristics of these bacteria is needed to answer this question. Based on current 
knowledge, it seems that the acid-sensitive ammonium-oxidizing chemolithotrophs have a selective advantage over the acid-tolerant ammonium-oxidizing chemolithotrophs in micro-sites with a relatively high $\mathrm{pH}$ because the growth rate of the former bacteria seems to be relatively high at $\mathrm{pH}>5$ (Chapter 3). Outside these micro-sites acid-tolerant ammonium-oxidizing bacteria are believed to have a selective advantage, because they can continue to be active at low $\mathrm{pH}$ values (Chapter 3).

Another point of interest is how the ammonium-oxidizing bacteria in heathland soils are located with respect to nitrite-oxidizing bacteria. It was shown that the oxidation of ammonium to nitrate in $0.1 \%$ humus suspensions at $\mathrm{pH} 4$ is very efficient $(95-100 \%)$ (undescribed experiment). This implies that uptake of $\mathrm{HNO}_{2}$ by acid-tolerant nitrite-oxidizing bacteria must be very rapid, because otherwise loss of mineral nitrogen via chemical reactions of $\mathrm{HNO}_{2}$ would have occurred. Therefore, it is believed that acid-tolerant ammonium-oxidizing bacteria and acid-tolerant nitrite-oxidizing bacteria are closely associated. It is possible that acid-tolerant nitrate production in heathland soils takes place in aggregates that contain both acid-tolerant ammonium- and nitrite-oxidizing bacteria. A study on the localization of chemolithotrophic nitrifying bacteria on a micro-scale is expected to reveal a great deal of information about the ecology of these bacteria in heathland and other acid soils.

\section{Interpretation of this study with respect to management practices}

Nitrate production in grass-dominated heathland soils was found to be a process that generally occurs. In heathland soils dominated by dwarf-shrubs production of nitrate was less general but in some of these soils the rate of nitrate production was as high as in grass-dominated heathland soils (Chapter 2). In soils from young dwarf-shrub heathlands, nitrate-producing bacteria were apparently not present (Chapter 4). It will be interesting to know more about the relationship between the age of dwarf-shrub stands and the occurrence of nitrate production. If it would appear that net nitrate production starts to occur in heathland soils as soon as they become dominated by grasses, then the measurement of net nitrate production can be useful to determine when management is required. Furthermore, the effect of management practices such as grazing and mowing can be evaluated by determining the potential net production of nitrate. These practices will be succesful if the amount of available ammonium, for plant growth, in heathland soils is becoming limited because under nitrogen-limited conditions dwarf-shrubs may again become dominant. A decrease in the potential of net nitrate production can give an indication that the availablity of ammonium is becoming limiting. 


\section{REFERENCES}

Adams J.A (1986a) Nitrification and ammonification in acid forest litter and humus as affected by peptone and ammonium-N amendment. Soil Biol. Biochem. 18, 45-51.

Adams J.A. (1986b) Identification of heterotrophic nitrification in strongly acid larch humus. Soil Biol. Biochem. 18, 339-341.

Adema E.H. (1984) Inleiding op het symposium zure regen. In: Zure regen oorzaken, effecten, beleid (E.H. Adema and J. van Ham, eds.), pp. 21-29. PUDOC, Wageningen, The Netherlands.

Anonymous (1987) STATISTTX: an interactive analysis program for microcomputers. NH Analytical Software, St. Paul MN 55117, USA.

Beck T. (1979) Die nitrifikation in böden. Z. Pflanzener. Bodenk. 142, 344-364.

Bédard C. and Knowles R. (1989) Physiology, biochemistry, and specific inhibitors of $\mathrm{CH}_{4}$, $\mathrm{NH}_{4}{ }^{+}$and $\mathrm{CO}$ oxidation by methanotrophs and nitrifiers. Microbiol. Rev. 53, 68-84.

Belser L.W.(1979) Population ecology of nitrifying bacteria Ann. Rev. Microbiol. 33, 309-333.

Berendse F. (1986) Stikstofmineralisatie en strooiselproduktie in voedselarme ecosystemen. Vakbl. Biol. 66, 430-433.

Berendse F.(1988) Een simulatiemodel als hulpmiddel bij het beheer van vochtige heidevelden. In: De nutriëntenbalans van droge zandgrondvegetaties in verband met de eutrofiëring via de lucht. deel 1. Publikatie $m 743, \mathrm{CABO}$, Wageningen, The Netherlands.

Berendse F., Beltman B., Bobbink B., Kwant R. and Schmitz M. (1987) Primary production and nutrient availability in wet heathland ecosystems. Oecol. Plant. 8, 265-279.

Berendse F., Bobbink R. and Rouwenhorst G. (1989) A comparative study on nutrient cycling in wet heathland systems.II. Litter decomposition and nutrient mineralization. Oecologia 78, 338-348.

Bertru G. and Goma Tchimbakala J. (1985) Influences des composés hydrosolubes des litières sur l'activité d'une population de Nitrobacter en chémostat. Rev. Ecol. Biol. Sol $22,433-440$.

Bhuiya Z.H. and Walker N. (1977) Autotrophic nitrifying bacteria in acid tea soils from Bangladesh and Sri Lanka. J. Appi. Bacteriol. 42, 253-257.

Bock E., Koops H-P. and Harms H. (1986) Cell biology of nitrifying bacteria. In: Nitrification (J.I. Prosser, ed.), pp. 17-37. IRL Press, Oxford, UK

Bonneau M. (1980) Production d'azote minéral dans divers types de landes du Massif Central. Central Ann. Sci. Forest 37, 173-188.

Booth I.R. (1985) Regulation of cytoplasmic pH in bacteria. Microb. Rev. 49, 359-378.

Boring L.R., Swank W.T., Waide J.B. and Henderson G.S. (1988) Sources, fates and impacts of nitrogen inputs to terrestrial ecosystems: review and synthesis. Biogeochem. 6, 119-159.

Bowman R.A. and Cole C.V. (1978) An exploratory method for fractionation of organic phosphorus from grassland soils. Soil Sci. 125, 95-101.

Brar S.S. and Giddens J. (1968) Inhibition of nitrification in Bladen grassland soil. Soil Sci. Soc. Am. Proc. 32, 821-823.

Buysman E., Maas H. and Asman W. (1984) Een gedetailleerde ammoniak emissiekaart van Nederland. Instituut voor Meteorologie en Oceanografie. Rijksuniversiteity Utrecht, Rapport No. V-84 2c.

Campbell C.A. (1987) Soil organic carbon, nitrogen and fertility. In: Soil organic matter (M. Schnitzer and S.U. Khan eds.) pp. 173-271, Elsevier, Amsterdam, The Netherlands.

Christensen N.L. and MacAller T. (1985) Soil mineral nitrogen transformations during succesion in the Piedmont of North Carolina. Soil Biol. Biochem. 171, 675-681.

Christensen S. and Tiedje J.M. (1988) Sub-parts-per-billion nitrate method: Use of an $\mathrm{N}_{2} \mathrm{O}$ - 
producing denitrifier to convert $\mathrm{NO}_{3}$ or ${ }^{15 \mathrm{NO}_{3}}$ to $\mathrm{N}_{2} \mathrm{O}$. Appl. Environm. Microbiol. 54, 1409-1413.

Clarholm M., Popovic B., Rosswall T., Söderström B., Sohlenius B., Staaf H. and Wirén $H$. (1981) Biological aspects of nitrogen mineralization in humus from a pine forest podsol incubated under different moisture and temperature conditions. Oikos 37, 137-145.

Clays-Josserand A., Lensi R. and Goubière F. (1988) Vertical distribution of nitrification potential in an acid forest soil. Soil Biol. Biochem. 20, 405-406.

Crutzen P.J. (1981) Atmospheric chemical processes of the oxides of nitrogen including nitrous oxide.In: Denitrification, nitrification and atmospheric nitrous oxide (C.C. Delwiche, ed.). pp. 17-44, John Wiley, New York, USA.

Dalal R.C. (1972) Colorimetric determination of aluminum in soil extracts using haematoxylin. Plant and Soil 36, 223-231.

Dancer W.S., Peterson L.A. and Chesters G. (1973) Ammonification and nitrification of N as influenced by soil $\mathrm{pH}$ and previous $\mathrm{N}$ treatments. Soil Sci. Soc. Am. J. 37,67-69.

Davy A.J. and Taylor K. (1974) Seasonal patterns of nitrogen availability in contrasting soils in Chiltern hills. J. Ecol. 62, 793-807.

De Smidt J.T. (1979) Heidevegetaties: Oorsprong, typologie en oecologie. Ned. Bosb. Tijdschrift 51, 53-63.

Focht D.D. and Verstraete W. (1977) Biochemical ecology of nitrification and denitrification. Adv. Microbiol. Ecol. 1, 135-214.

Fred E.B. and Graul E.J. (1916) Some factors that influence nitrate formation in acid soils. Soil Sci. 1, 317-318.

Gerlach A. (1973) Methodische untersuchungen zur bestimmung der stickstoff-mineralisation. Scripta Geobotanica, band 5, Universitat Göttingen, Western-Germany.

Gilmour J.T. (1984) The effects of soil properties on nitrification and nitrification inhibition. Soil Sci. Soc. Am. J. 48, 1262-1266.

Gimingham C.H. (1972) Ecology of heathlands. Chapman and Hall, London, UK.

Gimingham C.H. and de Smidt J.T. (1983) Heaths as natural and semi-natural vegetation. In: Man's impact on vegetation (W. Holzner, M.J.A. Werger and I. Ikusima, eds.). pp. 185-199. Dr W Junk Publishers, The Hague, The Netherlands.

Goring C.A.I. (1962) Control of nitrification by 2-chloro-,6-(trichloromethyl) pyridine. Soil Sci. $93,211-218$.

Hankinson T.R. and Schmidt E.L. (1984) Examination of an acid forest soil for ammoniaand nitrite-oxidizing bacteria. Can. J. Microbiol. 30, 1125-1132.

Hankinson T.R. and Schmidt E.L. (1988) An acidophilic and a neutrophilic Nitrobacter strain isolated from the numerically predominant nitrite-oxidizing population of an acid forest soil. Appl. Environm. Microbiol. 54, 1536-1540.

Heil G.W. (1984) Nutrients and the species composition of heathland. Doctoral Thesis, University of Utrecht, The Netherlands.

Heil G.W. and Diemont W.H. (1983) Raised nutrient levels change heathland into grassland. Vegetatio 53, 113-120.

Heil G.W. and Bruggink M. (1987) Competition for nutrients between Calluna vulgaris (L.) Hull and Molinia carulea (L.) Moench. Oecologia 73, 105-107.

Heilman P. (1974) Effect of urea fertilization on nitrification in forest soils of the Pacific Northwest. Soil Sci. Soc. Am. Proc. 38, 664-667.

Houba V.J.G., Van der Lee J.J., Walinga I. and Novozamsky I. (1985) Soil analysis, Part 2 (procedures). Department of Soil Science and Plant Nutrition, Wageningen Agricultural University.

Hyman M.R. and Wood P.M. (1985) Suicidal inactivation and labeling of ammonia monooxygenase by acetylene. Biochem. J. 227, 719.725. 
Hynes R.K. and Knowles R. (1982) Effect of acetylene on autotrophic and heterotrophic nitrification. Can. J. Microbiol. 28, 334-340.

Ishaque M. and Cornfield A.H. (1976) Evidence for heterotrophic nitrification in an acid Bangladesh soil lacking autotrophic nitrifying organisms. Trop. Agric. (Trinidad) 53, 157-160.

Jackson L.E., Schimel J.P. and Firestone M.K. (1989) Short-term partioning of ammonium and nitrate between plants and microbes in an annual grassland. Soil Biol. Biochem. 21, 409-415.

Jahns T., Zobel A., Kleiner D. and Kaltwasser H. (1988) Evidence for carrier-mediated, energy-dependent uptake of urea in some bacteria. Arch. Microbiol. 149, 377-383.

Jansson S.L. and Persson J. (1982) Mineralization and immobilization of soil nitrogen. In: Nitrogen in agricultural soils (F.J. Stevenson ed.). Agronomy 22, 229-252, Madison, Wisconsin, USA.

Johnsrud S.C. (1978) Heterotrophic nitrification in acid soils. Holarct. Ecol. 1, 27-30.

Josserand A. and Cleyet-Marel J.C. (1979) Isolation from soils of Nitrobacter and evidence for novel seroptypes using immunofluorescence. Microb. Ecol. 5, 197-205.

Kaila A. (1954) Nitrification in decomposing organic matter. Acta Agric. Scand. 4, 17.32.

Keen G.A and Prosser J.I. (1987) Interrelationship between $\mathrm{pH}$ and surface growth of Nitrobacter. Soil Biol. Biochem. 19, 665-672.

Keeney D.R. (1986) Sources of nitrate to groundwater. CRC Crit. Rev. Environm. Control. $16,257-303$.

Keeney D.R. and Nelson D.W. (1982) Nitrogen - inorganic forms. In: Methods of soil analysis. (A.L. Page, R.H. Miller and D.R. Keeney eds.). Agronomy 9, Part 2, 2nd edn., pp. 643-698. Madison, Wisconsin, USA.

Killham K. (1986) Heterotrophic nitrification. In: Nitrification (J.I. Prosser ed.), pp. 117-126. IRL Press, Oxford, UK.

Killham K. (1987) A new perfusion system for measurement and characterization of potential rates of soil nitrification. Plant and Soil 97, 267-272.

Klein T.M., Kreitinger J.P. and Alexander M. (1983) Nitrate formation in acid forest soils from the Adirondacks. Soil Sci. Soc. Am. J. 47, 1407-1410.

Kreitinger J.P., Klein T.M. Novick N.J. and Alexander M. (1985) Nitrification and nitrifying microorganisms in an acid forest soil. Soil Scj. Soc. Am. J. 49, 1407-1410.

Kuenen J.G. and Robertson L.A. (1987) Ecology of nitrification and denitrification. In: The nitrogen and sulphur cycles (J.A. Cole and S. Ferguson, eds.). pp. 162-218, Cambridge University Press, Cambridge, UK.

Lache D.W. (1976) Umweltbedingungen von binnendünen- und heidegesellschaften im Nordwesten Mitteleuropas. Scripta Geobotanica, Band 11, Universität Göttingen, Western-Germany.

Ladd J.N. and Jackson R.B. (1982) Biochemistry of ammonification. In: Nitrogen in agricultural soils (F.J. Stevenson ed.). Agronomy 22, pp. 173-228, Madison, Wisconsin, USA.

Lang E. and Jagnow G. (1986) Fungi of a forest soil nitrifying at low pH values. FEMS Microbiol. Lett. (Ecology) 38, 257-265.

Lensi R., Gourbière F. and Josserand A. (1985) Measurement of small amounts of nitrate in an acid soil by $\mathrm{N}_{2} \mathrm{O}$ production. Soil Biol. Biochem. 17, 733-734.

Lensi R., Mazurier S., Gourbière F. and Josserand A. (1986) Rapid determination of the nitrification potential of an acid forest soil and assesment of its variability. Soil Biol. Biochem. 18, 239-240.

Lettl A. (1985) Heterotrophic nitrifying bacteria in acid forest soils polluted by $\mathrm{SO}_{2}$. Folia Microbiol. 30, 509-516. 
Likens G.E., Borman F.H. and Johnson N.M. (1969) Nitrification: Importance to nutrient losses in cutover forested ecosystems. Science 163, 1205-1206.

Mai H. and Fiedler H.J. (1983) The effect of fertilization measures in forest on the microflora of the soil and surface water in a catchment area. Zentrallbl. Mikrobiol. 138, $427-435$.

Malhi S.S. and McGill W.B. (1982) Nitrification in three Alberta soils: Effect of temperature, moisture and substrate concentration. Soil Biol. Biochem. 141, 393-399.

Martikainen P.J. (1985) Numbers of autotrophic nitrifiers and nitrification in fertilized forest soil. Can. J. Microbiol. 31, 190-197.

Martikainen P.J. and Nurmiaho-Lassila E-L. (1985) Nitrosospira, an important ammoniumoxidizing bacterium in fertilized coniferous soil. Soil Biol. Biochem. 17, 245-248.

Matson P.A. and Vitousek P.M. (1981) Nitrogen mineralization and nitrification potentials following clearcutting in the Hoosier National Forest, Indiana. Forest Sci. 27, 781-791.

Matzner E. (1980) Untersuchungen zum elementhaushalt eines heide-ökosystem (Calluna vulgaris) in Nordwest-Deutschland. Göttinger Bodenkundl. Berichte 63, 1-120.

Mclean R.J.C., Cheng K-J, Gould W.D., Nickel J.C. and Costeron J.W. (1986) Histochemical and biochemical urease localization in the periplasm and outer membrane of two Proteus mirabilis strains. Can. J. Microbiol. 32, 772-778.

Morrill L.G. and Dawson J.E. (1962) Growth rates of nitrifying chemoautotrophs in soil. J. Bacteriol. 83,205-206.

Mulder J. (1988) Impact of acid atmospheric deposition on soils: Field monitoring and aluminum chemistry. Doctoral Thesis, Agricultural University, Wageningen, The Netherlands.

Müller M.M., Sundman V. and Skujins J. (1980) Denitrification in low pH spodosols and peats determined with the acetylene inhibition method. Appl. Environm. Microbiol. 40, 235-238.

Namir K.S., Guzev V.S. and Zvyagintsev D.G. (1986) Non specific effect of nitrification inhibitors on soil microorganisms. Microbiology 55, 295-300.

Nelson D.W. and Sommers L.E. (1982) Total carbon, organic carbon, and organic matter. In: Methods of soil analysis (A.L. Page, R.H. Miller and D.R. Keeney eds.). Agronomy 9, Part 2 ,2nd edn., pp. 539-579. Madison, Wisconsin, USA.

Novozamsky I., Houba V.J.G., Temminghoff E. and Van der Lee J.J. (1984) Determination of 'total' $\mathrm{N}$ and 'total' $\mathrm{P}$ in a single soil digest. Neth. J. Agric. Sci. 32, 322-324.

Nyborg M. and Hoyt P.B. (1978) Effects of soil acidity and liming on mineralization of soil nitrogen. Can J.Soil Sci. 58, 331-338.

Nye P.H. (1981) Changes of $\mathrm{pH}$ across the rhizosphere induced by roots. Plant and Soil 61, 7-26.

Olsen S.R., Cole C.V., Watanabe F.S. and Dean L.A. (1954) Estimation of available phosphorus in soils by extraction with sodium bicarbonate. USDA Circ. 939.

Olson R.K. and Reiners W.A. (1983) Nitrification in subalpine balsam fir soils: Tests for inhibitory factors. Soil Biol. Biochem. 15,413-418.

Overrein L.N. (1967) Immobilization and mineralization of tracer nitrogen in forest raw humus.I.Effect of temperature on the interchange of nitrogen after addition of urea-, ammonium- and nitrate-N15. Plant and Soil 27, 1-19.

Parnow R.J. (1972) Computer program estimates bacterial densities by means of the most probable numbers. Food Technol. 26, 56-62.

Pastor J., Aber J.D., McClaugherty C.A. and Melillo J.M. (1984) Aboveground production and $\mathbf{N}$ and $\mathbf{P}$ cycling along a nitrogen mineralization gradient on Blackhawk Island, Wisconsin. Ecology 65, 256-268.

Purchase B.S. (1974) The influence of phosphate deficiency on nitrification. Plant and Soil 41, 541-547. 
Raison R.J., Conell M.J. and Khanna P.K. (1987) Methodology for studying fluxes of soil mineral-N in situ. Soil Biol. Biochem. 19, 521-530.

Reddy K.R. (1982) Mineralization of nitrogen in organic soils. Soil Sci. Soc. Am. J. 46, 561-566.

Rice E.L. (1984) Allelopathy. Academic Press, New York, USA

Robertson L.A. (1988) Aerobic denitrification and heterotrophic nitrification in Thiosphaera pantotropha and other bacteria. Doctoral Thesis, Technical University, Delft, The Netherlands.

Robertson L.A and Kuenen J.G. (1988) Heterotrophic nitrification in Thiosphaera panthotropha - oxygen uptake and enzyme studies. J. Gen. Microbiol. 134, 857-863.

Robertson G.P. (1982a) Nitrification in forested ecosystems. Phil. Trans. R. Soc. Lond. 296, 445-457.

Robertson G.P. (1982b) Factors regulating nitrification in primary and secondary succesion. Ecology 63, 1561-1573.

Rozé F. (1988) Nitrogen cycle in Brittany heathland. Oecol. Plant. 9, 371-379.

Runge M. (1983) Physiology and ecology of nitrogen nutrition. In: Encyclopedia of plant physiology (O.L. Lange et al. eds.), New series 12C, Physiological Plant Ecology III. pp. 163-200, Springer Verlag, New York.

Sahrawat K.L. and Keeney D.R. (1986) Nitrous oxide emission from soils. Adv. Soil Sci. 4, 103-148.

Saunders W.M.H. and Williams E.G. (1955) Observations on the determination of total organic phosphorus in soils. J. Soil Sci. 6, 254-267.

Scheu S. (1987) Microbial activity and nutrient dynamics in earthworm casts (Lumbricidae) Biol. Fertil. Soils 5, 230-234.

Schildwacht P.M. and de Smidt J.T. (1984) The effect of nutrient availability and management on the species composition of a dry heathland. Utrecht Plant Ecol. News Rep. 1, 47-53.

Schimel J.P., Firestone M.K. and Killham K.S. (1984) Identification of heterotrophic nitrification in an Sierran forest soil. Appl. Environm. Microbiol. 48, 802-806.

Schmidt E.L. (1982) Nitrification in soil. In: Nitrogen in agricultural soils (F Stevenson, ed.). Agronomy 22, pp. 253-283, Madison, Wisconsin, USA.

Schmidt E.L. and Belser L.W. (1982) Nitrifying bacteria. In: Methods of soil analysis (A.L. Page, R.H. Miller and D.R. Keeney, eds.). Agronomy 9, Part 2, 2nd ed., pp. 1027-1042, Madison, Wisconsin, USA.

Schneider T. and Bresser A.H.M (1987) Dutch priority programme on acidification. Verzuringsonderzoek eerste fase. Tussentijdse evaluatie. Rapport 00-04, RIVM, Bilthoven, The Netherlands.

Schneider T. and Bresser A.H.M. (1988) Dutch priority programme on acidification. Additioneel programma verzuringsonderzoek. Evaluatierapport verzuring. Rapport 00-06 RIVM, Bilthoven, The Netherlands.

Seneca H., Peer P. and Nally R. (1962) Microbial urease. Nature 193: 1106-1107.

Smith A.J. and Hoare D.S. (1977) Specialist phototrophs, lithotrophs and methylotrophs: A unity among a diversity of procaryotes? Bact. Rev. 41, 419-448.

Srivasta S.C. and Singh J.S. (1988) Carbon and phosphorus in the soil biomass of some tropical soils of India. Soil Biol. Biochem. 20, 743-747.

Stroo H.F., Klein T.M. and Alexander M. (1986) Heterotrophic nitrification in an acid forest soil by an acid-tolerant fungus. Appl. Environm. Microbiol. 52, 1107-1111.

Tate III R.L. (1977) Nitrification in histosols: A potential role for the heterotrophic nitrifier. Appl. Environm. Microbiol. 33, 911-914.

Topp E. and Knowles R. (1982) Nitrapyrin inhibits the obligate methylotrophs Methylosinus trichosporium and Methylococcus capsalatus. FEMS Microbiol. Lett. 14, 47-49. 
Van Breemen N., Burrough P.A., Velthorst E.J., van Dobben H., Toke de Wit, Ridder T.B. and Reijnder H.F.R.(1982) Soil acidification from atmospheric ammonium sulphate in forest canopy throughfall. Nature 299, 548-550.

Van Breemen N., Mulder J. and van Grinsven J.J.M. (1987) Impacts of acid atmospheric deposition on woodland soils in the Netherlands: Nitrogen-transformations. Soil Sci. Soc. Am. J. 51, 1634-1640.

Van de Dijk S.J, and Troelstra S.R. (1980) Heterotrophic nitrification in a heath soil demonstrated by an in situ method. Plant and Soil 57, 11-21.

Van Gelder T. (1988) De heide heeft toekomst. Rapport Werkgroep Heidebehoud en Heidebeheer, Staatsbosbeheer Utrecht, The Netherlands.

Van Gils H. (1983) De heide als weide. Vakl. Biol. 63, 196-199.

Van Miegroet H. and Cole D.W. (1984) The impact of nitrification on soil acidification and cation leaching in a red alder ecosystem. Environm. Qual. 13, 586-590.

Van Miegroet H. and Cole D.W. (1985) Acidification in red alder and douglas fir soils: Importance of nitrification. Soil Sci. Soc. Am. J. 49, 1274-1279.

Vitousek P.M. and Matson P.A. (1985) Causes of delayed nitrate production in two Indiana forests. Forest Sci. 31, 122-131.

Vitousek P.M., Gosz J.R., Grier C.C., Melillo J.M. and Reiners W.A. (1982) A comparative analysis of potential nitrification and nitrate mobility in forest ecosystems. Ecol. Monogr. $52,155-177$.

Vogels G.D., Van der Drift C. (1969) Hydrolysis of allantoate. Rec. Trav. Chim. Pays-Bas. $88,951-957$.

Vonk J.W. (1988) Soil acidification and microbial processes: the fate of inorganic nitrogen in acid heathland and forest soil. Report no. R 87/331, RIVM, Bilthoven, The Netherlands.

Wall L.L., Gehrke C.W., Neuner T.E., Cathey R.D. and Rexnord P.R. (1975) Cereal protein nitrogen: Evaluation and comparison of four different methods. J. Assoc. Off. Anal. Chem. 58, 811-817.

Walker N. and Wickramasinghe K.N. (1979) Nitrification and autotrophic nitrifying bacteria in acid tea soils. Soil Biol. Biochem. 11, 231-236.

Watanabe F.S. and Olsen S.R. (1965) Test of an ascorbic acid method for determing phosphorus in water and $\mathrm{NaHCO}_{3}$ extracts from soil. Soil Sci. Soc. Amer. Proc. 29, $677-$ 678.

Watanabe I., Padre Jr. B.C. and Santiago S.T. (1981) Quantitative study on nitrification in flooded rice soil. Soil Sci. Plant Nutr. 27, 373-382.

Watson S.W., Valois F.W. and Waterbury J.B. (1981) The family Nitrobacteraceae. In: The prokaryotes (N.P. Starr, H. Stolp, H.G. Trüper, A. Balows and Schlegel H.G. eds.), pp. 1005-1022, Springer-Verlag, New York.

Watson S.W., Bock E., Harms H., Koops H.P. and Hooper A.B. (1989) Nitrifying bacteria. In: Bergey's manual of systematic bacteriology, Vol. 3 (J.T. Staley, M.T. Bryant, N. Pfennig and J.G. Holt eds.), pp. 1808-1834, Williams and Wilkins, Baltimore, USA.

Weber D.F. and Gainey P.L. (1982) Relative sensitivity of nitrifying organisms to hydrogen ions in soils and solutions. Soil Sci. 94, 138-145.

Weier K.L. and Gilliam J.W. (1986) Effect of acidity on nitrogen mineralization and nitrification in Atlantic Coastal Plain soils. Soil Sci. Soc. Am. J. 50, 1210-1214.

White C.S. and Gosz J.R. (1987) Factors controlling nitrogen mineralization and nitrification in forest ecosystems in New Mexico. Biol. Fert. Soils 5,195-202.

Wood P.M. (1986) Nitrification as a bacterial energy source. In: Nitrification (JI Prosser, ed.), pp. 39-62. IRL Press, Oxford, UK. 


\section{SUMMARY}

This thesis is the result of a study on the production of nitrate in Dutch heathland soils. Most of the heathlands are located on acid, sandy soils. Therefore, it has dealt mainly with the occurrence, nature and mechanisms of nitrification in acid soils. In the Netherlands, the production of nitrate in acid soils is a matter of great concern because it has become obvious that this process contributes to a continuous acidification of such soils that are exposed to high levels of deposition of ammonia and ammonium. Continuous acidification of sandy soils has a negative impact on the vitality of trees. Moreover, the groundwater may become polluted with nitrate and aluminum.

As almost all Dutch heathlands are semi-natural in origin, management practices, such as sod-cutting, are needed to maintain the original dwarf-shrub vegetation. At present, the replacement of dwarf-shrubs by grasses is a big problem for management. This change in dominancy coincides with the increase in the availability of mineral nitrogen for plants which, in turn, is attributed to high levels of deposition of $\mathrm{NO}_{x}$ and $\mathrm{NH}_{x}$ originating from industry, traffic and intensive animal husbandry. Grasses may become dominant under conditions of relatively high nitrogen availability.

In this study, it was indicated that the high availability of mineral nitrogen has also resulted in the general occurrence of nitrification in Dutch heathland soils (Chapter 2 and 4). Nitrification was not restricted to heathlands that were dominated by certain plant species. Nitrification in Dutch heathland soils appeared to be regulated by the availability of ammonium and oxygen whereas the availability of phosphate may also be important (Chapter 2 and 4). The presence of nitrification was not dependent on the $\mathrm{pH}$ of the heathland soils. Most of the production of nitrate in Dutch heathland soils was shown to take place in the organic horizon (Chapter 2 and 3).

Using inhibitors it could be concluded that chemolithotrophic bacteria are the main nitrifying micro-organisms in Dutch heathland soils, despite their low $\mathrm{pH}$ (Chapter 3 and 4). The effect of $\mathrm{pH}$ on the activity of chemolithotrophic nitrifying bacteria was studied using suspensions that were maintained at $\mathrm{pH} 4$ or 6 . During these experiments nitrite never accumulated in detectable amounts. Therefore, it is concluded that the rate of production of nitrate is dependent on the activity of ammonium-oxidizing bacteria. Evidence is presented for the existence of chemolithotrophic ammonium-oxidizing bacteria that are active at $\mathrm{pH} 4$ (Chapter 3). These acid-tolerant bacteria are present in many heathland soils (Chapter 4). In suspensions of $\mathrm{pH} 4$ production of nitrate was exponential. This implies that the acid-tolerant ammonium-oxidizing bacteria are able to grow at low $\mathrm{pH}$ values (Chapter 3). The in situ oxidation of ammonium in many Dutch heathland soils is most likely caused by acid-tolerant, ammonium-oxidizing bacteria (Chapter 3 and 4). Unfortunately, little is known about the characteristics of these bacteria because attempts to isolate them have thusfar been unsuccesful. The isolation of acid-tolerant ammonium-oxidizing bacteria is hindered by their inability to be active at low $\mathrm{pH}$ without the presence of humus particles (Chapter 3 and 8). 
Acid-sensitive ammonium-oxidizing bacteria are also present in Dutch heathland soils. These bacteria are not able to nitrify in suspensions at $\mathrm{pH} 4$. It is believed that the nitrifying activity of these bacteria in acid soils is mainly restricted to micro-sites with a relatively high $\mathrm{pH}$. In this study two additional mechanisms were proposed to explain the activity of acid-sensitive ammonium-oxidizing bacteria in an acid soil without the need for assuming the presence of such micro-sites.

- The first mechanism deals with the activation of acid-sensitive ammonium-oxidizing bacteria by ammonia produced by ammonifying micro-organisms (Chapter 5 and 8 ). This possibility was proposed to explain that, at low $\mathrm{pH}$, nitrification seemed to be linked to net nitrogen mineralization in suspensions of heathland soils that contained only acid-sensitive ammonium-oxidizing bacteria (Chapter 5).

- The second mechanism deals with the activation of acid-sensitive ammonium oxidizing bacteria by urea. Urea stimulated the production of nitrate at $\mathrm{pH} 5$ in many suspensions of heathland soils containing acid-sensitive ammonium-oxidizing bacteria (Chapter 3, 4 and 6). An acid-sensitive ammonium-oxidizing strain isolated from a heathland soil showed urease activity (Chapter 6). This strain was able to nitrify at $\mathrm{pH} 4.5$ in a medium containing urea, whereas it was not capable of doing so at $\mathrm{pH}$ values lower than 5.5 , in a medium containing ammonium (Chapter 7).

Acid-sensitive ammonium-oxidizing bacteria are however not believed to be important for in situ production of nitrate in Dutch heathland soils (Chapter 3 and 4).

Information concerning nitrite-oxidizing bacteria in heathland soils is very scarce at the moment. Still, it is obvious that acid-tolerant nitrite-oxidizing bacteria are present in heathland soils that showed nitrate production in suspensions of $\mathrm{pH} 4$. It appeared that, even at $\mathrm{pH} \mathrm{4,} \mathrm{acid-tolerant} \mathrm{nitrite-oxidizing} \mathrm{bacteria} \mathrm{were} \mathrm{able} \mathrm{to}$ efficiently oxidize the nitrite produced by ammonium-oxidizing bacteria (Chapter 8 ). 


\section{SAMENVATTING}

Dit proefschrift is het resultaat van een onderzoek naar de produktie van nitraat in heidebodems. Aangezien de meeste Nederlandse heidevelden worden aangetroffen op zure zandbodems heeft het onderzoek zich met name gericht op de aard en het mechanisme van nitraatvorming onder zure omstandigheden. Momenteel wordt er in Nederland, vanuit milieu-oogpunt, veel aandacht besteed aan de produktie van nitraat (nitrificatie) in zure bodems omdat dit proces in belangrijke mate blijkt bij te dragen aan de verdere verzuring van de met ammonium en ammoniak belaste zandgronden. Verzuring is waarschijnlijk één van de belangrijkste oorzaken van de achteruitgang van bossen in gebieden met zandbodems. Bovendien kan het grondwater door verzurende processen verontreinigd raken met nitraat en aluminium.

De meeste Nederlandse heidevelden vormen half-natuurlijke landschappen die alleen door toepassing van beheersmaatregelen, bijvoorbeeld afplaggen, in stand kunnen worden gehouden. Eén van de grootste problemen waarmee het beheer van de Nederlandse heidevelden momenteel wordt geconfronteerd is de toenemende vergrassing. Deze wordt voor een belangrijk deel geweten aan de door industrie, verkeer en landbouw veroorzaakte hoge $\mathrm{NO}_{x^{-}}$en $\mathrm{NH}_{x}$-depositie, hetgeen heeft geleid tot een hogere beschikbaarheid van minerale stikstof voor planten. Onder dergelijke stikstof-rijke omstandigheden kunnen grassen de voor de heide kenmerkende dwergstruiken verdringen.

Uit dit onderzoek is gebleken dat de verhoogde beschikbaarheid van minerale stikstof waarschijnlijk ook heeft geleid tot het algemeen voorkomen van nitraatvorming in de Nederlandse heidebodems (Hoofdstuk 2 en 4). Nitrificatie kon zowel in vergraste - als niet-vergraste heidevelden worden aangetoond.

Factoren die de vorming van nitraat in heidebodems lijken te bepalen zijn de ammoniumbeschikbaarheid, de zuurstofvoorziening en mogelijk de fosfaatbeschikbaarheid (Hoofdstuk 2 en 4). Het voorkomen van nitrificatie bleek niet of slechts in beperkte mate te worden bepaald door de $\mathrm{pH}$ van de heidebodem. De produktie van nitraat in heidebodems lijkt voornamelijk plaats te vinden in de organische horizont (Hoofdstuk 2 en 3 ).

Ondanks de lage $\mathrm{pH}$ is het zeer waarschijnlijk dat chemolithotrofe nitrificerende bacteriën verantwoordelijk zijn voor de vorming van nitraat in heidebodems, zoals onder andere uit experimenten met remmers van het enzym ammonia monooxygenase kon worden geconcludeerd (Hoofdstuk 3 en 4). Het effect van de $\mathrm{pH}$ op de aktiviteit van de in de heidebodem aanwezige nitrificerende bacteriën is onderzocht met suspensies die op pH 4 of 6 werden gesteld. Bij deze experimenten vond nooit ophoping van nitriet plaats zodat geconcludeerd kan worden dat de snelheid van nitraatvorming bepaald wordt door de aktiviteit van ammonium-oxyderende bacteriën. In veel heidebodems blijken ammonium-oxyderende bacteriën voor te komen die bij pH 4 aktief zijn (Hoofdstuk 4). Daarom worden deze bacteriën zuur-tolerant genoemd. De produktie van nitraat in suspensies van $\mathrm{pH} 4$ verliep exponentieel hetgeen erop duidt dat zuur-tolerante, ammonium-oxyderende bacteriën daadwerkelijk in staat zijn tot groei onder zure omstandigheden (Hoofdstuk 3). 
Deze bacteriën spelen waarschijnlijk een belangrijke rol bij de nitraatvorming in situ (Hoofdstuk 3 en 4). Helaas kan over de eigenschappen van zuur-tolerante ammonium-oxyderende bacteriën nog maar weinig worden gezegd omdat pogingen tot isolatie tot dusverre niet zijn geslaagd. Isolatie van zuur-tolerante ammoniumoxyderende bacteriën wordt bemoeilijkt doordat ze bij lage $\mathrm{pH}$ alleen in aanwezigheid van humus aktiviteit vertonen (Hoofdstuk 3 en 8).

In heidebodems blijken ook zuur-gevoelige ammonium-oxyderende bacteriën voor te komen. Deze bacteriën zijn in suspensies van $\mathrm{pH} 4$ niet aktief. Verondersteld wordt dat de aktiviteit van deze bacteriën in zure bodems voornamelijk beperkt is tot micro-sites met een relatief hoge $\mathrm{pH}$. Op basis van de onderzoeksresultaten zijn twee mogelijkheden voorgesteld om de aktiviteit van zuur-gevoelige ammoniumoxyderende bacteriën in zure bodems te verklaren waarbij het niet noodzakelijk is de aanwezigheid van dergelijke micro-sites te veronderstellen.

- De eerste mogelijkheid is de aktivering van zuur-gevoelige ammonium-oxyderende bacteriën door ammoniak dat geproduceerd wordt door ammonificerende microorganismen (Hoofdstuk 5 en 8). Deze mogelijkheid is geopperd om te kunnen verklaren dat nitrificatie en stikstof-mineralisatie bij lage $\mathrm{pH}$ gekoppeld lijken te zijn in suspensies van een heidebodem waarin alleen zuur-gevoelige ammoniumoxyderende bacteriën voorkomen (Hoofdstuk 5).

- De tweede mogelijkheid is de aktivering van zuur-gevoelige ammonium-oxyderende bacteriën door ureum. In heidebodems met zuur-gevoelige ammonium-oxyderende bacteriën blijkt de produktie van nitraat in suspensies bij pH 5 vaak gestimuleerd te worden door ureum (Hoofdstuk 3, 4 en 6). Een zuur-gevoelige ammoniumoxyderende bacterie die uit een heidebodem werd geisoleerd bleek urease aktiviteit te bezitten (Hoofdstuk 6). Deze bacterie was in staat bij pH 4.5 te nitrificeren indjen het kweekmedjum ureum bevatte, terwijl nitrificatie met ammonium als substraat beneden $\mathrm{pH} 5.5$ niet plaats vond (Hoofdstuk 7).

De zuur-gevoelige ammonium-oxyderende bacteriën lijken echter voor de in situ produktie van nitraat in heidebodems van weinig belang te zijn (Hoofdstuk 3 en 4).

De informatie over nitriet-oxyderende bacteriën in heidebodems is nog zeer beperkt. Duidelijk is echter dat zuur-tolerante nitriet-oxyderende bacteriën aanwezig zijn in alle heidebodems waarin produktie van nitraat in suspensies bij $\mathrm{pH} 4$ kon worden gemeten. Bovendien blijken deze bacteriën in staat om bij lage $\mathrm{pH}$ het door de ammonium-oxydeerders geproduceerde nitriet zeer efficient om te zetten tot nitraat (Hoofdstuk 8). 


\section{APPENDIX}

GENERAL SOIL CHARACTERISTICS OF DUTCH HEATHLAND SITES 
General soil characteristics - per dominant plant species individual data for the $0-5 \mathrm{~cm}$ layer (FH included) and average profile data for the $0-25 \mathrm{~cm}$ depth - are presented in Tables 1 to 4 for Calluna, Erica, Deschampsia, and Molinia, respectively.

The $\mathrm{pH}$ refers to dried material and showed per depth no significant differences among means. The $\mathrm{pH}$ range in the top layer was from 3.5 to 4.6 (mean 3.9-4.0) and values increased slightly at greater depths; generally, the $\mathrm{pH}$ of field-moist samples was $0.1-0.2$ units higher. The $\mathrm{pH}$ range found for the $0.5 \mathrm{~cm}$ layer was the same as reported for the FH layer (Chapter 4) and both data sets were highly correlated ( $R=0.76$; soil/solution ratio in both cases 1:5). Mean values of organic $C$ and total $N$ were per layer not significantly different for the 4 plant species, but ranges could be fairly wide, particulary organic $\mathrm{C}$ in the top layer. Although not significantly different, organic $\mathrm{C}$ values were relatively high at the generally wetter sites of Erica and Molinia. A difference was observed for the mean $\mathrm{C} / \mathrm{N}$ ratio in the $0.5 \mathrm{~cm}$ depth, with Erica sites $(\mathrm{C} / \mathrm{N}=29.3)$ significantly higher than Deschampsia $(\mathrm{C} / \mathrm{N}=25.2)$ or Molinia sites $(\mathrm{C} / \mathrm{N}=24.4)$. Mean $\mathrm{C} / \mathrm{N}$ ratios were relatively constant at greater depths with an overall range of 27.1-32.6.

Total phosphorus contents showed considerable variation, especially at Deschampsia sites, and differences were found to be significant for the $0-5$ and $5-10 \mathrm{~cm}$ depths: higher means at Deschampsia sites (17.6 and $16.7 \mathrm{mg} P / 100 \mathrm{cc}$ ) than at Molinia sites $(6.9$ and $6.3 \mathrm{mg} P / 100 \mathrm{cc})$. Most of the $P$ at these heathland sites is organically bound and total organic $P$ values (not shown) often amounted to more than $95 \%$ of total $\mathrm{P}$. Whereas available inorganic $\mathrm{P}$ (Olsen-P) did not differ significantly among plant species, mean values of labile organic $P$ were clearly higher at Deschampsia sites $(3.75$ and $4.34 \mathrm{mg} P / 100 \mathrm{cc}$ for $0-5$ and $5-10 \mathrm{~cm}$ depth, respectively) and differed significantly from Erica sites $(1.82 \mathrm{mg} P / 100 \mathrm{cc}$ ) in the $0-5$ $\mathrm{cm}$ layer, and from all three other sites $(1.47-1.89 \mathrm{mg} P / 100 \mathrm{cc})$ in the $5-10 \mathrm{~cm}$ depth. We preferred the Olsen-P extraction to measure available inorganic $P$, because it allows the simultaneous determination of the labile organic $\mathbf{P}$ fraction. However, since the Olsen-P extraction was originally developed for calcareous soils, two other extraction procedures were also run on the $0-5 \mathrm{~cm}$ layer samples. A highly significant correlation was found between Olsen-P and Bray-P (Table 5), both methods extracting essentially similar amounts of soil P. The P-water method also extracted roughly similar amounts of $P$, but relatively more at the lower values for Olsen-P and Bray-P, causing the correlations between P-water and Olsen-P or Bray$P$ to be only slightly less significant (Table 5).

Cation levels were generally not significantly different among plant species. Oxalate-extractable $\mathrm{Fe}$ and $\mathrm{Al}$ amounts were roughly comparable between the species and increased with depth (data not shown); observed ranges (for the $0-5$ and $15-25 \mathrm{~cm}$ depths, respectively) were $1.0-1.6$ and $2.5-4.1 \mathrm{mmol} \mathrm{Fe} / 100 \mathrm{cc}$, and $1.8-2.4$ and 6.3-9.5 mmol $\mathrm{Al} / 100 \mathrm{cc}$. $\mathrm{K}, \mathrm{Ca}$ and $\mathrm{Mg}$ concentrations were highest in the top 5 cm. Exchangeable $\mathrm{Al}$ was significantly and negatively correlated with $\mathrm{pH}$ in all depths (R-values of $-0.44,-0.42,-0.44$ and -0.57 for $0-5,5-10,10-15$, and $15-25 \mathrm{~cm}$ respectively; $\mathrm{P}<0.001-0.01$ ), but concentrations (as was the case with oxalateextractable $\mathrm{Al}$ ) increased down the profile with a slight increase in $\mathrm{pH}$. 


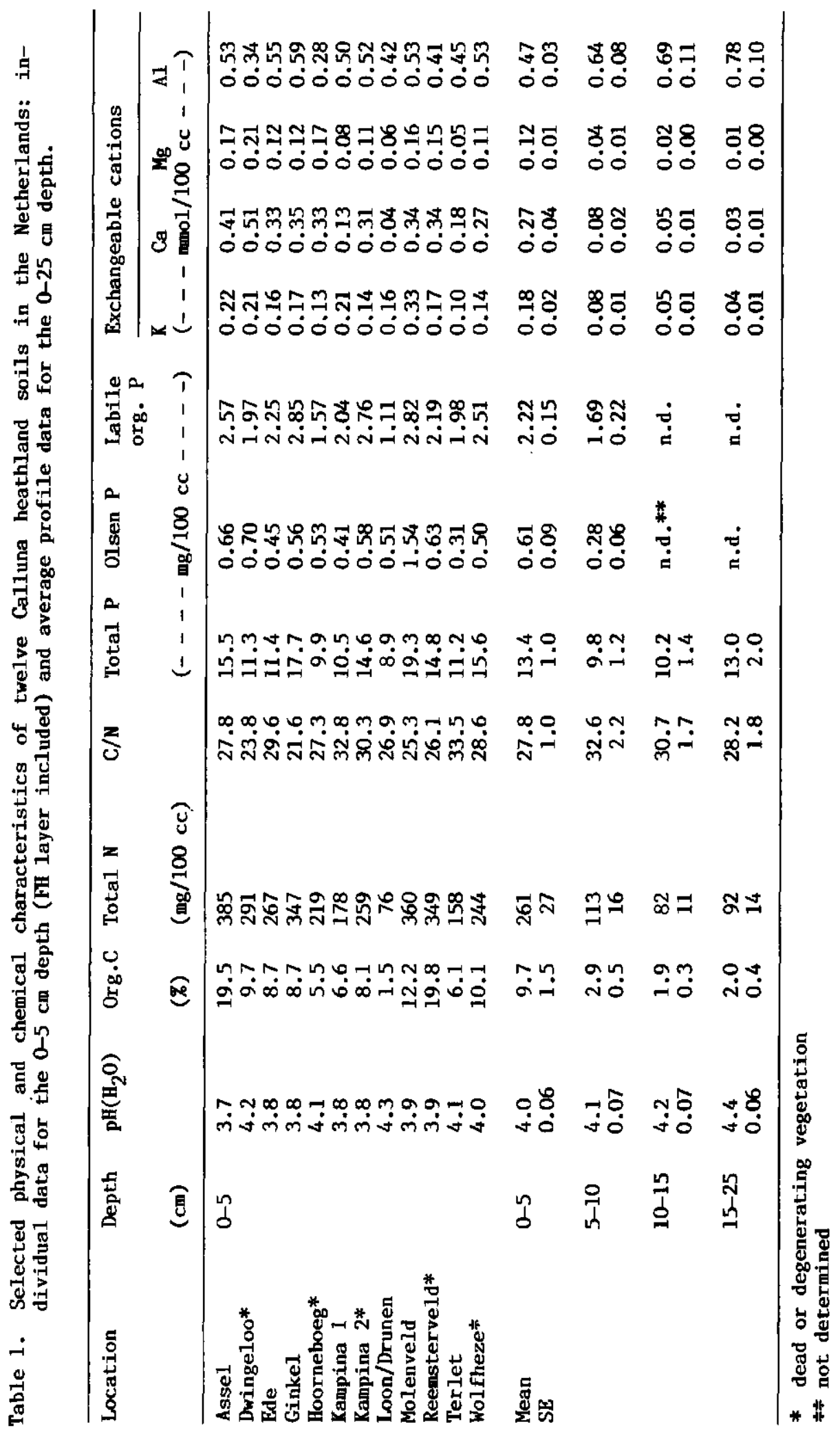




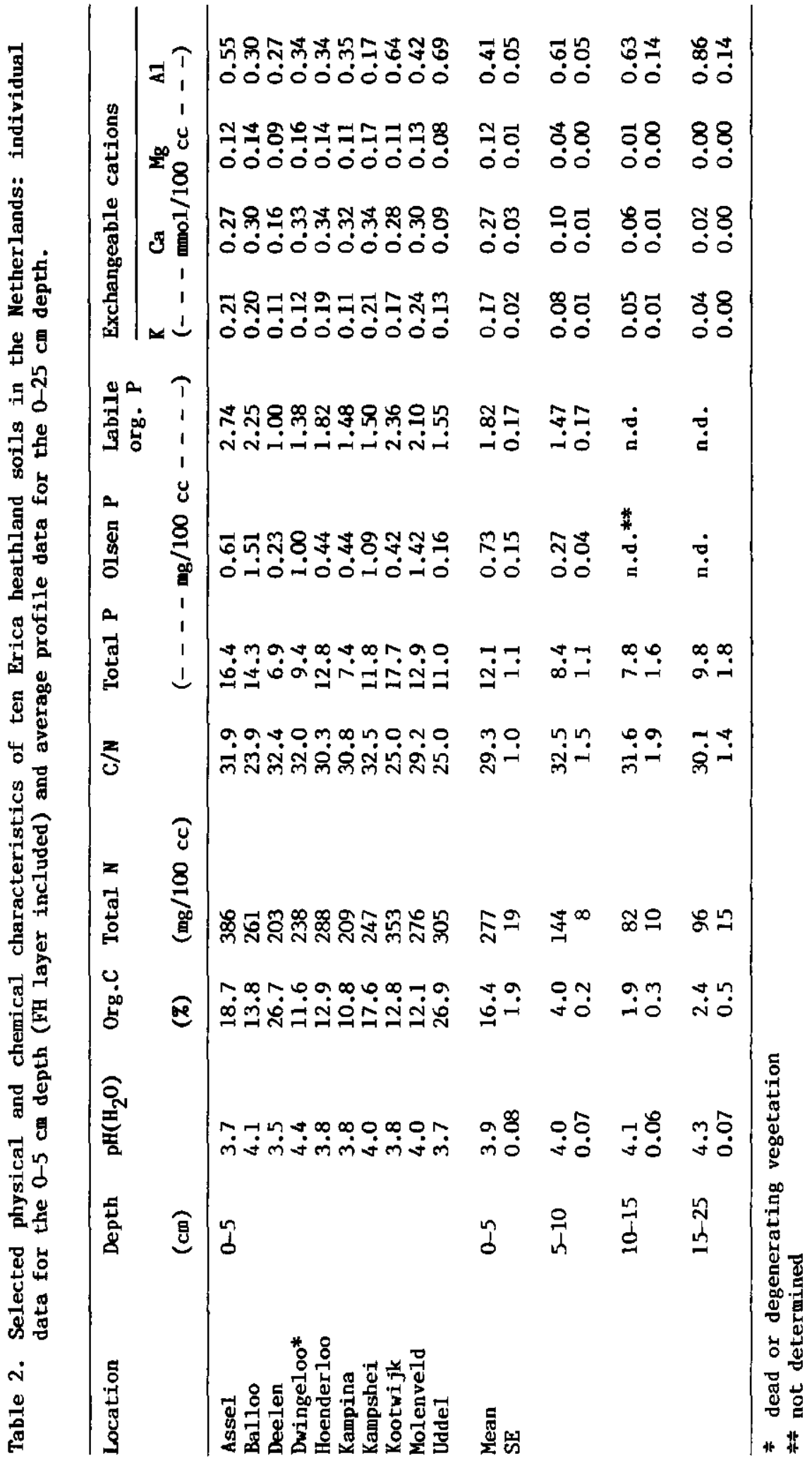




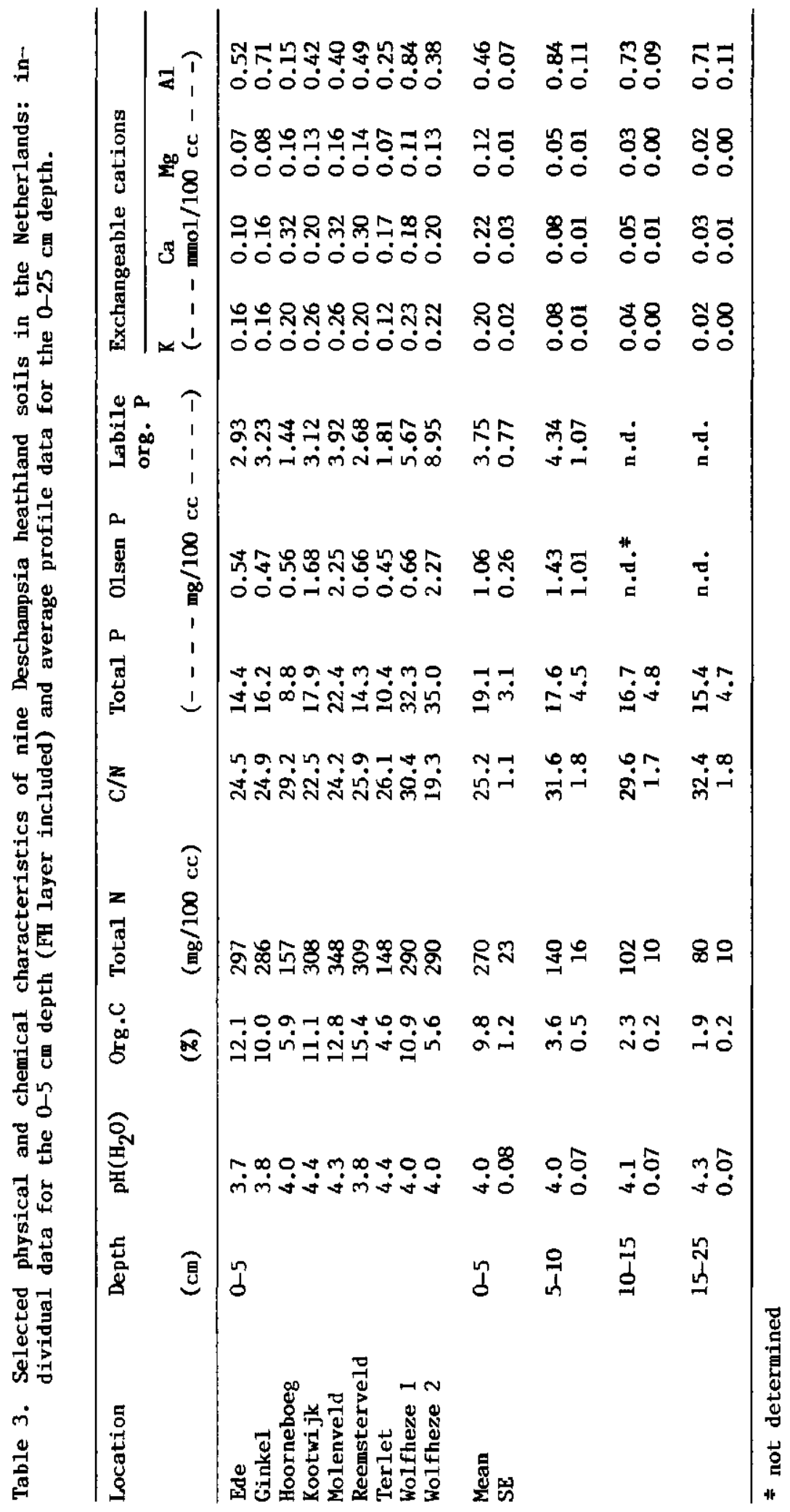




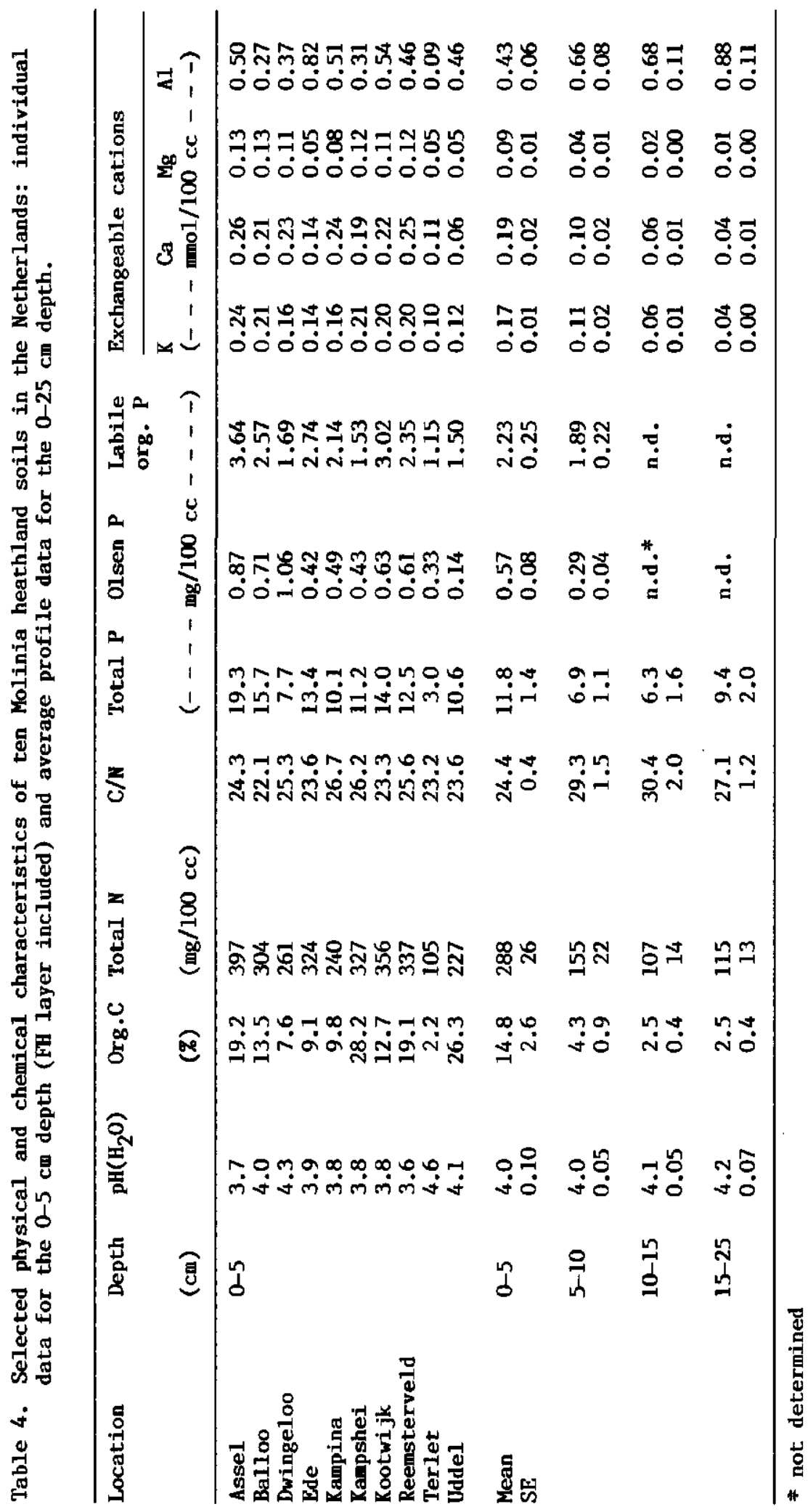


Table 5. Correlation matrix for some $P$ parameters of heathland soils $(n=41)$. Data refer to the $0.5 \mathrm{~cm}$ depth ( FH Layer included), expressed on a soil volume basis.

1

$\begin{array}{lll}2 & 3 & 4\end{array}$

56

1. Total P

2. Total organic $\mathbf{P}$

3. P water

0.96

4. P-Bray

0.31

0.43

0.57

0.93

$0.91 \quad 0.88$

4

5. P-Olsen

6. Labile organic $P$

7. Total $\mathrm{NaHCO}_{3} \mathrm{P}$

0.32

0.32

0.66

0.75

0.28

0.45

0.95

$\begin{array}{ll}0.43 & 0.57\end{array}$

$\begin{array}{lll}0.62 & 0.75 & 0.97\end{array}$

values $>0.40$ are significant at the $1 \%$ level; $>0.50$ significant at the $0.1 \%$ level 


\section{CURRICULUM VITAE}

Wietse de Boer werd geboren op 6 april 1957 te Assen. In juni 1975 behaalde hij het diploma Gymnasium B aan het Dr. Nassau College te Assen. In hetzelfde jaar begon hij met de studie Biologie aan de Rijksuniversiteit Groningen. Het kandidaatsexamen, met als hoofdvakken Biologie en Bodemkunde, werd in juli 1979 behaald. Tijdens de doctoraalfase heeft hij onderzoekservaring opgedaan bij de Vakgroepen Microbiologie (oecologische microbiologie), Plantenoecologie en Genetica (moleculaire genetica). Na zijn afstuderen, in 1983, is hij werkzaam geweest als verpleeghulp op "het Mariëncamp' te Rolde en als onbezoldigd onderzoeker bij de Vakgroep Biochemie van de Rijksuniversiteit Groningen. In september 1985 is hij aangesteld voor een 4-jarig promotie-onderzoek naar de vorming van nitraat in heidebodems, bij de afdeling Bodembiologie van het Instituut voor Oecologisch Onderzoek te Heteren. De resultaten van het onderzoek zijn beschreven in dit proefschrift. Inmiddels werkt hij, binnen een gezamelijk onderzoeksprojekt van het Instituut voor Oecologisch Onderzoek en het Fysisch Geografisch en Bodemkundig Laboratorium van de Universiteit van Amsterdam, verder aan de microbiologie van nitraatvorming in zure bos- en heidebodems. 